\title{
44. COMPOSITION OF FERROMANGANESE CRUSTS AND NODULES AT NORTHWESTERN PACIFIC GUYOTS AND GEOLOGIC AND PALEOCEANOGRAPHIC CONSIDERATIONS ${ }^{1}$
}

\author{
Y.A. Bogdanov, ${ }^{2}$ O.Y. Bogdanova, ${ }^{2}$ A.V. Dubinin, ${ }^{2}$ A. Gorand, ${ }^{3}$ A.I. Gorshkov, ${ }^{2}$ E.G. Gurvich, ${ }^{2}$ A.B. Isaeva, ${ }^{2}$ \\ G.V. Ivanov, ${ }^{2}$ L.F. Jansa, ${ }^{4}$ and A. Monaco ${ }^{5}$
}

\begin{abstract}
The chemical and mineralogical compositions of ferromanganese crusts collected from surfaces of northwestern Pacific guyots during Ocean Drilling Program (ODP) Leg 144 show that they are mainly hydrogenous deposits; that is, they have been formed by the slow accumulation of trace metal enriched oxides directly from the seawater column. The formation of crusts occurred over a period of 30 (and possibly even 60-90) m.y., when guyots were carried "piggy-back" by the oceanic plates across the equatorial zone of the central Pacific. The guyots simultaneously experienced vertical displacement caused by isostatic adjustment that exposed them to the influence of water masses having different chemical compositions. Crust precipitation may have occurred when current velocity over the tops of these guyots oscillated between 1 and $38 \mathrm{~cm} / \mathrm{s}$ and the surface of the guyots subsided through the water column from $\sim 400 \mathrm{~m}$ to $\sim 1050 \mathrm{~m}$ water depth (i.e., when the guyot surfaces were located within the low-oxygen zone, or near its lower boundary).

Two mineralogical assemblages dominated by (1) asbolane-buserite at the northern guyots and (2) Fe-vernadite at the southern guyots record differences in bioproductivity during crust precipitation. The presence of both mineral assemblages in crusts at the Wodejebato Guyot demonstrates the complexity of processes and the importance of the local environment on crust deposition. Increased concentrations of $\mathrm{Co}, \mathrm{Ni}, \mathrm{Mn}$, and $\mathrm{P}$ were noted in crusts deposited in the equatorial high-productivity belt. Both positive and negative $\mathrm{Ce}$ anomalies were observed in samples of crusts collected at the same depth level, but at different locations on the same guyot. The behavior of $\mathrm{Ce}$ is covariant with $\mathrm{Mn}$ and antipathic with $\mathrm{P}$. The trace element and rare earth element (REE) analyses presented by this study suggest that the chemical composition of crusts is more strongly influenced by the combined effects of bioproductivity, relative position of the oxygen-minimum zone, and the current velocity, rather than by the water depth where the crusts precipitate.

Our interpretation of the composition of $\mathrm{Fe}-\mathrm{Mn}$ crust and nodules, as paleoceanographic indicators, suggests that the Late Cretaceous-early Tertiary (90-60 Ma) was a period of lower biogenic productivity over the equatorial Pacific than during the Tertiary, extrinsic to low intensity of upwelling and equable climate. Several periods of increased bottom current velocity and bioproductivity during the late Paleocene-early Eocene ( $60-50 \mathrm{Ma})$ indicate an increase in upwelling as the higher latitudes began to cool, thus developing a steeper thermal gradient in the southern ocean. Increased bioproductivity and an increased depositional rate of pelagic carbonate at the equatorial belt during the late Oligocene-early Miocene smothered $\mathrm{Fe}-\mathrm{Mn}$ crust precipitation at the southern guyots.
\end{abstract}

\section{INTRODUCTION}

The western Pacific is strewn with chains and clusters of Cretaceous seamounts (Fig. 1). Most of the seamounts are guyots that have a flat top and summit at depths of approximately $1500 \mathrm{~m}$ (Menard, 1964; McNutt et al., 1990). The guyots are considered to be old drowned islands, frequently capped by pelagic carbonate that overlies a shallow-water carbonate platform, which in turn is underlain by volcanic rocks (Premoli Silva, Haggerty, Rack, et al., 1993; Sager, Winterer, Firth, et al., 1993). Ocean Drilling Program (ODP) Legs 143 (Sager, Winterer, Firth, et al., 1993) and 144 (Premoli Silva, Haggerty, Rack, et al., 1993) were designed to study in detail the geologic history of northwestern Pacific guyots. The Fe-Mn oxyhydroxides (hereafter called crusts and nodules) were found to commonly coat surfaces of drowned shallow-water carbonate platforms, and/or surfaces of the altered igneous substrate of the guyots. The formation and chemical composition of these crusts and nodules differs from deep-sea ferromanganese nodules because of variances in the sedimentation regime, bioproductivity, and water chemistry.

'Haggerty, J.A., Premoli Silva, I., Rack, F., and McNutt, M.K. (Eds.), 1995. Proc ODP, Sci. Results, 144: College Station, TX (Ocean Drilling Program).

${ }^{2}$ P.P. Shrishov Institute of Oceanology, Russian Academy of Sciences, Krasikova Street 23, Moscow 117218, Russian Federation.

${ }^{3}$ Centre de Microscopie Electronique, Université de Perpignan, Perpignan, France.

${ }^{4}$ Atlantic Geoscience Centre, Bedford Institute of Oceanography, Dartmouth, Nova Scotia, B2Y 4A2 Canada.

${ }^{5}$ Laboratoire de Sédimentologie et Géochimie Marines, Université de Perpignan, Perpignan, France.
The guyots presently found in the northwestern Pacific formed during Cretaceous time in the southeastern Pacific, at paleolatitudes that are equivalent to the present location of French Polynesia (McNutt et al., 1990). The seamounts have moved horizontally northwestward from the site of formation (southeast Pacific) to their present location (northwest Pacific) while experiencing vertical displacement as a result of isostatic subsidence, complicated by tectonic rejuvenation. Hence, over a 90-m.y. period, changes in plate motion subjected the guyots to a score of changing oceanographic conditions as they crossed the high-productivity equatorial belt and were exposed to various current regimes. Additionally, as a result of isostatic subsidence of the volcanic pedestals, the surface of the guyots passed through water masses having different chemical compositions, which further affected the chemistry and diagenetic history of the crusts. Furthermore, because the subsidence of the guyots and their lateral movement across the equatorial Pacific occurred at different geologic times, the crusts that formed within a window between 90 and $30 \mathrm{Ma}$ also recorded changes in the past chemical composition of the surface and intermediate water masses. The combination of these principal variables results in a very complex textural and compositional signature that is characteristic of the Fe-Mn crusts deposited on the surfaces of the guyots discussed herein.

The backtracked trajectory of the guyots (Larson et al., this volume) indicates that they crossed the equator near a paleolongitude of $170^{\circ} \mathrm{E}$ and thus terrestrial sources and mid-ocean ridge volcanism probably did not contribute significantly to the composition of Fe-Mn crusts and nodules. Since the hydrogenetic Fe-Mn crusts formation is mainly controlled by the supply of metal from the oceanic water 


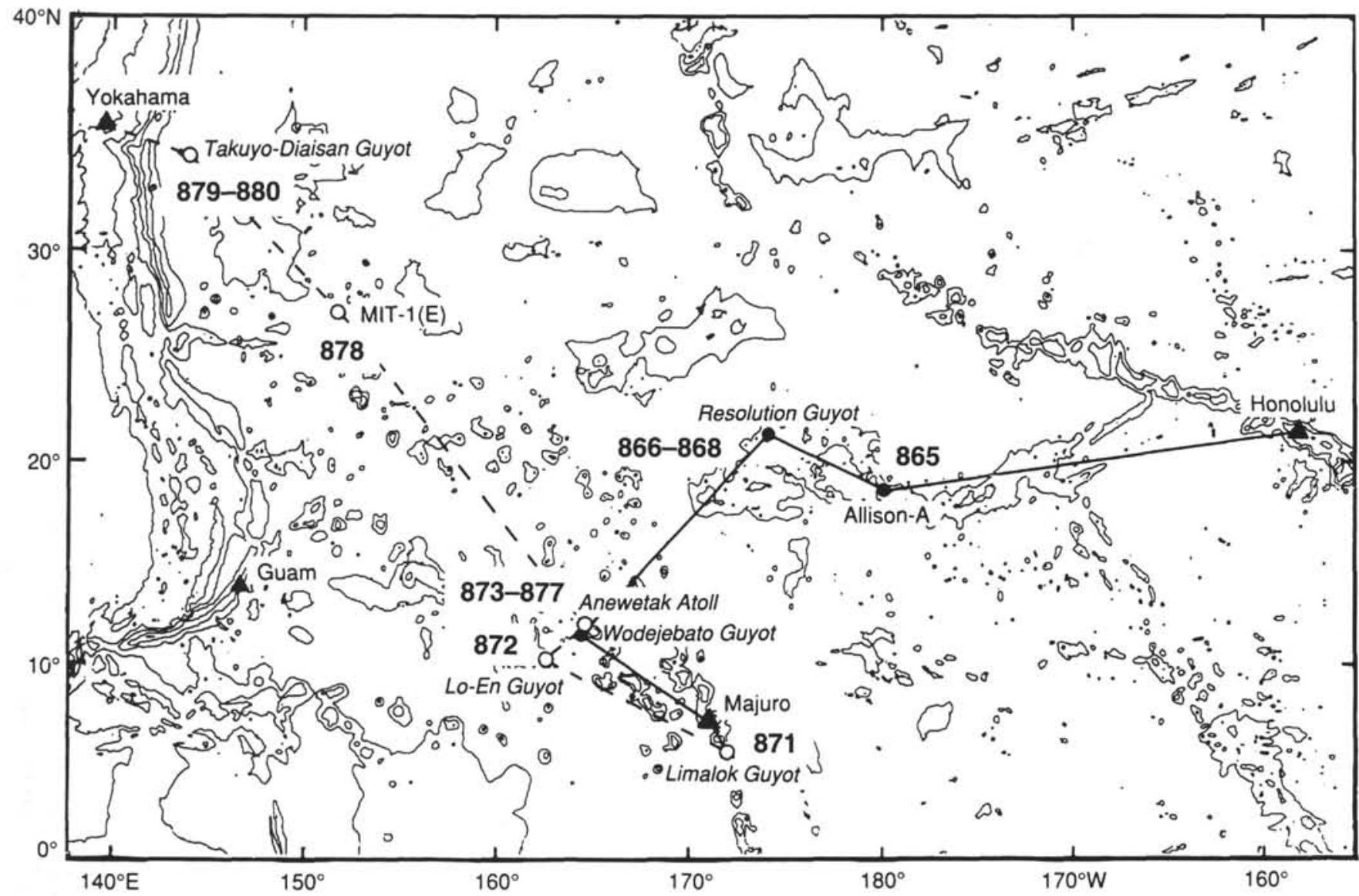

Figure 1. Generalized ship track with drill-site locations for Legs 143 and 144. Solid line represents Leg 143 track; the solid circles show Leg 143 drill sites. Dashed line shows Leg 144 track; open circles denote Leg 144 drill sites. Bathymetric contours from DBDB5 gridded bathymetry data set. The figure also shows the multitude of seamounts and guyots (small circles and dots) located in the northwestern Pacific Ocean.

column, the chemical signature inherited by the Fe-Mn crusts represents the product of a changing paleocean affecting the surface and intermediate water masses of the equatorial Pacific. The crusts that form in an oxidizing environment grow by the slow precipitation from near-bottom seawater of inorganic colloidal particles that consist of hydrated metal oxides.

Halbach and Puteanus (1984) suggested that the occurrence and composition of Fe-Mn crust are related to the regional morphology. According to the aforementioned authors, the intervening valleys on the surface of the seamount are filled by pelagic sediments and thus are free of Fe-Mn deposits, but on the slopes of seamounts the exposed surfaces of altered basaltic, volcanogenic, or the younger lithified sedimentary rocks are covered by thick Fe-Mn crusts with an average Co content of about $1 \%$. Crusts from seamount plateaus and the upper parts of slopes were predicted to be enriched in as much as $2 \% \mathrm{Co}$. In crusts, $\mathrm{Mn}$ and $\mathrm{Ni}$ are positively correlated with $\mathrm{Co}$, whereas $\mathrm{Cu}$, according to Halbach et al. (1982), shows an inverse relationship.

The crusts recovered from the top of guyots drilled during Leg 144 (Fig. 1) were taken from plateau areas with guyot surfaces currently at 1084 to $1525 \mathrm{~m}$ (Table 1), thus providing an opportunity to test Halbach and Puteanus' (1984) hypothesis about morphological relationships and the chemical composition of the Fe-Mn crusts. Furthermore, De Carlo (1991) and Hein et al. (1992) have suggested that the extremely fine and compact lamination in crusts results from the slow growth rates under oxic conditions with a lower bottom activity. Intensified bottom-water flow is required for formation of columnar (pillar) and botroydal crusts. Our study contributes new information about current activity during Fe-Mn crust precipitation.
The principal aim of this study is to apply the results of studies of $\mathrm{Fe}-\mathrm{Mn}$ crusts, their structure, and chemical and mineralogical composition to the interpretation of depositional processes and paleoceanographic events that affected crust precipitation. The data obtained from $\mathrm{Fe}-\mathrm{Mn}$ crusts recovered during Leg 144 contribute to filling a 60-m.y. (90-30 Ma) gap in the sediment record, when the Fe-Mn crusts were deposited on guyot surfaces located in intermediate water depths of the pelagic carbonate depositional realm. The paleoceanographic record in the equatorial Pacific for the remaining 30 m.y. can be reconstructed from the chemical composition of pelagic carbonate caps deposited at the guyot surfaces.

From the data presented herein, we conclude that the chemical record inherited by the $\mathrm{Fe}-\mathrm{Mn}$ oxyhydroxides precipitated at the top of seamounts and guyots can be correctly interpreted only if it is placed in a dynamic framework of plate motion and seamount subsidence; furthermore, the sample coverage must include several different areas of the seamount to eliminate the influence of the local environment on crust composition.

\section{METHODS}

The textural composition of Fe-Mn crusts and nodules was studied with a Hitachi S-520 scanning electron microscope. The chemistry of mineral phases was determined using a JEM-1OOC analytical electron microscope with Kevex-5100 energy dispersion equipment that produced electron diffraction patterns and energy dispersion spectra from particles as small as a fraction of a micron. Chemical analyses of a few selected mineral phases were performed using a 
Table 1. Location of guyots and stratigraphic position of Fe-Mn crusts and nodule, Leg 144.

\begin{tabular}{|c|c|c|c|c|c|c|c|c|}
\hline \multirow[b]{2}{*}{ Guyot } & \multirow[b]{2}{*}{ Site } & \multirow{2}{*}{$\begin{array}{l}\text { Latitude, } \\
\text { longitude }\end{array}$} & \multirow{2}{*}{$\begin{array}{l}\text { Depth } \\
\text { (m) }\end{array}$} & \multicolumn{2}{|c|}{ Pelagic carbonate cap } & \multirow{2}{*}{$\begin{array}{l}\text { Infiltrated sediment } \\
\text { in crust age }\end{array}$} & \multicolumn{2}{|c|}{ Substrate } \\
\hline & & & & Thickness (m) & Age & & Age & Rock type \\
\hline Limalok & 871 & $\begin{array}{l}5^{\circ} 33^{\prime} 43^{\prime \prime} \\
172^{\circ} 20^{\prime} 66^{\prime \prime}\end{array}$ & 1255 & 133.7 & $\begin{array}{l}\text { Pleistocene to } \\
\text { early Miocene }\end{array}$ & early Oligocene & middle Eocene & ca \\
\hline Lo-En & 872 & $\begin{array}{l}10^{\circ} 05^{\prime} 85^{\prime \prime} \\
162^{\circ} 51^{\prime} 96^{\prime \prime}\end{array}$ & 1084 & $141.7-143.6$ & $\begin{array}{l}\text { Pleistocene to } \\
\text { late Oligocene }\end{array}$ & $\begin{array}{l}\text { latest Santonian } \\
\text { middle Eocene }\end{array}$ & $?$ & $\mathrm{v}$ \\
\hline \multirow[t]{5}{*}{ Wodejebato } & 873 & $\begin{array}{l}11^{\circ} 53^{\prime} 84^{\prime \prime} \\
164^{\circ} 55^{\prime} 20^{\prime \prime}\end{array}$ & 1334 & 54.3 & $\begin{array}{l}\text { Pleistocene to } \\
\text { early Miocene }\end{array}$ & $\begin{array}{l}\text { late Paleocene } \\
\text {-middle Eocene }\end{array}$ & Maastrichtian & $\mathrm{ca}$ \\
\hline & 874 & $\begin{array}{l}12^{\circ} 00^{\prime} 74^{\prime \prime} \\
164^{\circ} 55^{\prime} 22^{\prime \prime}\end{array}$ & 1374 & 0 & - & $\begin{array}{l}\text { late Paleocene } \\
\text {-middle Eocene }\end{array}$ & Maastrichtian & ca \\
\hline & 875 & $\begin{array}{l}12^{\circ} 00^{\prime} 72^{\prime \prime} \\
164^{\circ} 56^{\prime} 44^{\prime \prime}\end{array}$ & 1409 & 0 & - & $\begin{array}{l}\text { late Paleocene } \\
\text {-middle Eocene }\end{array}$ & Maastrichtian & $\mathrm{ca}$ \\
\hline & 876 & $\begin{array}{l}12^{\circ} 01^{\prime} 47^{\prime \prime} \\
164^{\circ} 55^{\prime} 90^{\prime \prime}\end{array}$ & 1399 & 0 & - & $\begin{array}{l}\text { late Paleocene } \\
\text {-middle Eocene }\end{array}$ & Maastrichtian & $\mathrm{ca}$ \\
\hline & 877 & $\begin{array}{l}12^{\circ} 01^{\prime} 14^{\prime \prime} \\
164^{\circ} 55^{\prime} 30^{\prime \prime}\end{array}$ & 1355 & 0 & - & $\begin{array}{l}\text { late Paleocene } \\
\text {-middle Eocene }\end{array}$ & Maastrichtian & ca \\
\hline MIT & 878 & $\begin{array}{l}27^{\circ} 19^{\prime} 14^{\prime \prime} \\
151^{\circ} 53^{\prime} 03^{\prime \prime}\end{array}$ & 1323 & 3.2 & $\begin{array}{l}\text { Pleistocene to } \\
\text { late Miocene }\end{array}$ & early Eocene & Albian & $\mathrm{ca}$ \\
\hline \multirow[t]{2}{*}{ Takuyo-Daisan } & 879 & $\begin{array}{l}34^{\circ} 10^{\prime} 46^{\prime \prime} \\
144^{\circ} 18^{\prime} 56^{\prime \prime}\end{array}$ & 1501 & 0 & - & Albian & & $\mathrm{ca}$ \\
\hline & 880 & $\begin{array}{l}34^{\circ} 12^{\prime} 53^{\prime \prime} \\
144^{\circ} 18^{\prime} 74^{\prime \prime}\end{array}$ & 1525 & 18.4 & $\begin{array}{l}\text { late Pliocene } \\
\text { to Pleistocene }\end{array}$ & - & - & $?$ \\
\hline
\end{tabular}

Notes: Fe-Mn oxyhydroxides were deposited as crusts and coatings during the nondeposition period that followed drowning of the shallow carbonate platforms and/or the volcanic surface of the guyot. Infiltrated sediment in crust age represents pelagic sediment preserved in Fe-Mn crust cracks and as Fe-Mn nodule nucleii and infiltrated as a matrix into basal conglomerate. Sediment ages were based on nannofossils (Premoli Silva, Haggerty, et al., 1993; Watkins et al., this volume). Substrate rocks represented by shallow-water limestones were based on biostratigraphy, except at Lo-En Guyot where the limestone is missing (Premoli Silva, Haggerty, et al., 1993). The rock type represents the type of substratum underlying the Fe-Mn crust, with $\mathrm{ca}=$ shallow-water carbonate platform and $\mathrm{v}=$ volcanic and igneous rocks of the seamount.

Tracor Northern TN-5500 spectrometer and a Cameca-SX50 electron microprobe.

Relative percentages of $\mathrm{Fe}, \mathrm{Mn}, \mathrm{Ti}, \mathrm{Ni}, \mathrm{Co}, \mathrm{V}$, and $\mathrm{Zn}$ were determined by X-ray fluorescence using an automatic SPARK-1 spectrometer. The accuracy of the determinations was $\pm 3 \%$ for $\mathrm{Fe}, \pm 7 \%$ for $\mathrm{Mn}, \pm 10 \%$ for $\mathrm{Ti}, \pm 7 \%$ for $\mathrm{Ni}, \pm 10 \%$ for $\mathrm{Co}, \pm 15 \%$ for $\mathrm{V}$, and $\pm 20 \%$ for $\mathrm{Zn}$. The percentages of $\mathrm{Si}, \mathrm{Al}$, and $\mathrm{P}$ were determined by colorimetry. Total and organic carbon were determined using an AN7560 carbon analyzer (an analogue of the LECO-WR-12 carbon analyzer). The accuracy of these determinations was $0.01 \%$. Rareearth element (REE) concentrations in crusts and nodules were determined by inductively coupled plasma-mass spectroscopy (ICP-MS). The sample preparation methods and the determination procedure were published by Dubinin (1993). The mineralogy of individual crusts was determined by X-ray diffraction using a Guinier-type focusing camera and by electron scanning microscopy using an energy dispersion attachment to identify the morphology and elemental composition of separate oxide minerals.

\section{LOCATION, GEOLOGIC FRAMEWORK, AND Fe/Mn CRUSTS STRATIGRAPHY}

During Leg 144, five guyots were drilled along a northwesterly located track. The drilling commenced at the Limalok Guyot (Site 871 ) at $5^{\circ} 33^{\prime} \mathrm{N}$ (Fig. 1), and terminated at Takuyo-Daisan Guyot (Site 879 ) at $34^{\circ} 12^{\prime} \mathrm{N}$ latitude. The investigated guyots span about $30^{\circ}$ latitude and $30^{\circ}$ longitude. The stratigraphic framework of the guyots is presented in Table 1 and generalized in Figure 2, which shows a three-part subdivision of sedimentary deposits that overlie the volcanic pedestal of the guyots. These deposits are (1) a shallow-water carbonate platform, or an atoll-like carbonate build-up (Jansa and Arnaud Vanneau, this volume) that overlies the top of the volcano; (2) an Fe-Mn oxyhydroxide-encrusted top of the drowned carbonate platform, or, where the latter is missing (e.g., Lo-En Guyot), the crust coats the igneous rock substrate; and (3) a pelagic carbonate cap that buries the Fe-Mn crusts, except near the outer perimeter of the guyots.

This three-part subdivision is identifiable on the reflection seismic profile across the Limalok Guyot as well as across the northeastern flank of the Wodejebato Guyot. At the latter guyot, the pelagic carbonate cap overlies the guyot interior and pinches out at the guyot periphery where the surface is coated by $\mathrm{Fe}-\mathrm{Mn}$ crust. The Fe-Mn crust precipitation may have continued at the interior surface of this guyot for up to 35 m.y. and at the periphery of the guyot for up to 65 m.y.

The Leg 144 drilling results demonstrated not only a latitudinally related diachronous demise of the shallow-water carbonate build-ups (Premoli Silva, Haggerty, Rack, et al., 1993), but also diachronic initiation of Fe-Mn crust precipitation and in pelagic carbonate cap deposition (Fig. 2A). The most northern guyots, Takuyo-Daisan (Site 879/880) and MIT (Site 878; Fig. 1), have the oldest carbonate buildup constructed during Aptian-Albian time. In contrast, at the most southern Limalok Guyot (Site 871; Fig. 1), similar deposits are of late Paleocene to middle Eocene age (Premoli Silva, Haggerty, Rack, et al., 1993). The drowning that followed the deposition of the carbonate platform is also diachronous, with a strong latitudinal affinity (Larson et al., this volume), shown in Figure $2 \mathrm{~A}$. This allows reconstruction of an idealized sequence of geologic events in a northwestern Pacific guyot that is pertinent to the $\mathrm{Fe}-\mathrm{Mn}$ crust deposition, as follows:

1. construction of the seamount south of $10^{\circ}-20^{\circ} \mathrm{S}$ latitude;

2. shallow-water carbonate deposition;

3. the demise of the shallow-water carbonate platform and its drowning after the guyot migrates to approximately $7^{\circ} \mathrm{S}$ latitude (Fig. 3);

4. a period of nondeposition of $\mathrm{CaCO}_{3}$, mineralization, phosphatization, and $\mathrm{Fe}-\mathrm{Mn}$ crust and nodule precipitation at the substratum surface while the guyot migrates from about $7^{\circ} \mathrm{S}$ to about $2^{\circ}-3^{\circ} \mathrm{S}$ paleolatitude and subsides from $\sim 400$ to $800-1050 \mathrm{~m}$ water depth (Fig. 2B);

5. deposition of pelagic carbonate cap beginning at about $2^{\circ}-3^{\circ} \mathrm{S}$ paleolatitude as the guyots migrate through the equatorial belt during the late Cenozoic and continuing to the Holocene;

6. nondeposition and strong dissolution of pelagic carbonate at guyots that migrated through similar latitudes during the Late Cretaceous (MIT and Takuyo-Daisan guyots; L.F. Jansa et al., unpubl. data), with $\mathrm{Fe}-\mathrm{Mn}$ crust precipitation initiated at about $1^{\circ} \mathrm{N}$ paleolatitude. 
A

CARBONATE PLATFORM, PELAGIC CARBONATE CAP AND Fe-Mn CRUST DEPOSITION TIME SPAN - LEG 143, 144

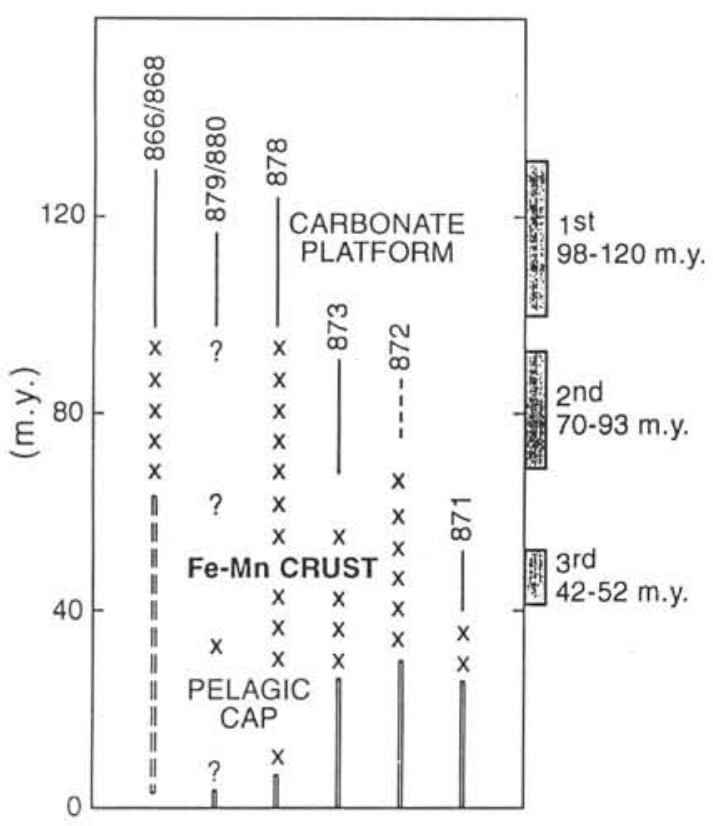

Figure 2. A. Diagram schematically shows relationship between age of different sedimentary rocks (shallow-water carbonate platform = single line, $\mathrm{Fe}-\mathrm{Mn}$ oxyhydroxides $=x x x x$ 's, pelagic carbonate $\mathrm{cap}=$ double line) deposited at the surface of the northwestern Pacific guyots. Age data is based on biostratigraphic studies in Premoli Silva, Haggerty, Rack, et al. (1993). B. Guyot subsidence after Parsons and Sclater (1977) and data provided by R.L. Larson (pers. comm., 1993). The time period of Fe-Mn crust precipitation is shown by thick black lines. Note that initiation of Fe-Mn crust precipitation occurred when the guyot surface was submerged to about $400 \mathrm{~m}$. The short line with cross-hatched symbol represents the present depth of the guyot surface. Short horizontal line with triangular symbol shows the top of the carbonate platform, when plotted on the guyot subsidence curve. Comparison of the data shows that subsidence curve provides values about $50-150 \mathrm{~m}$ too shallow for the Limalok and Wodejebato Guyots. The revision of paleodepth for termination of Fe-Mn crust precipitation at Wodejebato Guyot is $900 \mathrm{~m}$ ( $850 \mathrm{~m}$ is given in the figure).

The variation in chemical composition and morphology of Fe-Mn crusts broadly follows a subdivision into a southern and northern group of guyots.

\section{The Southern Group of Guyots $\left(5^{\circ}-12^{\circ} \mathrm{N}\right)$}

The southern group of guyots is represented by Limalok (Site 871), Lo-En (Site 872), and Wodejebato (Sites 873-877) guyots. These guyots have Fe-Mn crusts overlain by a pelagic, homogeneous, well-sorted, and winnowed foraminiferal ooze (Pl. 1, Fig. 1). The ooze has a medium sand-sized texture with pelagic foraminifer tests ranging from 0.1 to $0.25 \mathrm{~mm}$ in diameter; at the base of each sequence, the 0.25 -mm-diameter fraction is dominant, however. At Lo-En Guyot, the basal part of the pelagic cap is of late Oligocene age, whereas at Limalok and Wodejebato guyots the basal age is early Miocene. The pelagic carbonate caps of the southern guyots are discomformably underlain by several centimeters to a few tens of a centimeter of a rubble of $\mathrm{Fe}-\mathrm{Mn}$ coated limestone clasts and pebbles (Pl. 1, Fig. 2), some of which enclose older pelagic carbonate as an infiltrated conglomerate matrix (Watkins et al., this volume). The

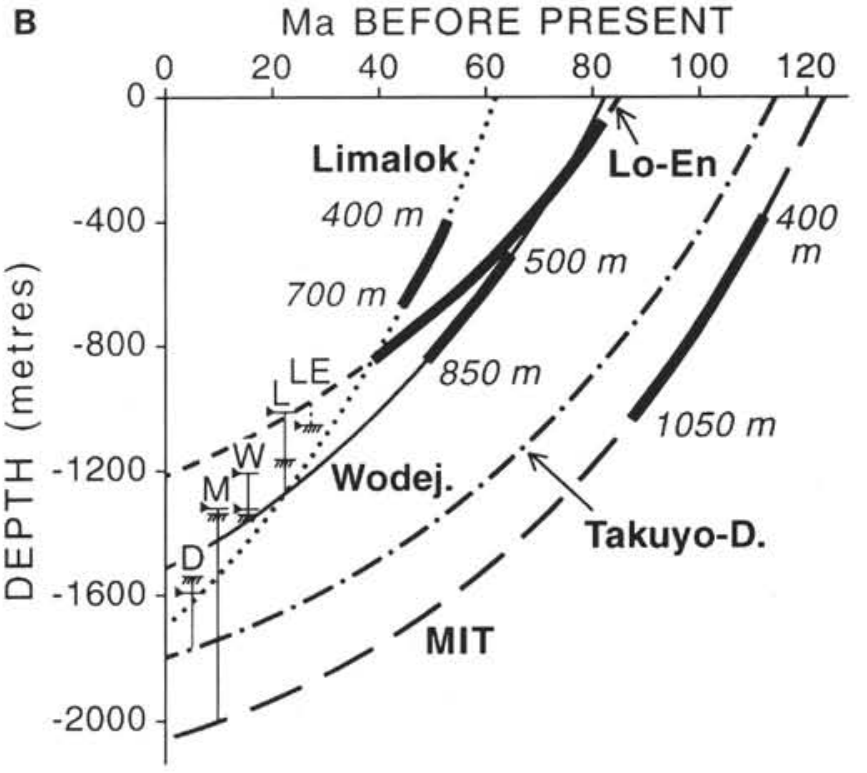

\section{GUYOT SUBSIDENCE (Parsons \& Sclater, 1977)}

Figure 2 (continued).

basal pebbly bed overlies the surface of a shallow-water carbonate platform of middle Eocene age at Limalok Guyot and a platform of Maastrichtian age at Wodejebato Guyot (Table 1). At Wodejebato Guyot, the overlying pebbly bed is of middle Eocene to late Paleocene age; at Lo-En Guyot, the corresponding bed is of late Paleocene age (Premoli Silva, Haggerty, Rack, et al., 1993). Fe-Mn crusts ( $3 \mathrm{~cm}$ thick) coat the top of this basal pebbly bed at Limalok and Wodejebato guyots (Sites 871 and 873) as well as the weathered surface of the volcanic pedestal at Lo-En Guyot (Site 872).

\section{The Northern Group of Guyots $\left(27^{\circ}-35^{\circ} \mathrm{N}\right)$}

The northern group includes MIT and Takuyo-Daisan guyots. At these sites, the pelagic cap is mostly missing. Pelagic carbonate is preserved only in pockets in the irregular surfaces of the guyots, with some of the pockets in the relief being more than $30 \mathrm{~m}$ deep at MIT Guyot (Premoli Silva, Haggerty, Rack, et al., 1993). In one of the shallow depressions on MIT Guyot, where Site 878 is located, pelagic carbonate ( $3.2 \mathrm{~m}$ thick) encloses scattered $\mathrm{Fe}-\mathrm{Mn}$ nodules (up to $5 \mathrm{~cm}$ diameter) and micronodules (Pl. 1, Fig. 3). The pelagic carbonate is of late Miocene to Pliocene age. It discomformably overlies a drowned shallow-water carbonate platform of Albian age (Premoli Silva, Haggerty, Rack, et al., 1993). The Fe-Mn nodule and crust precipitation in the surface depressions of MIT Guyot may have occurred anytime between Cenomanian and early Miocene time (90$23 \mathrm{Ma}$ ). Outside of the depressions in the guyot surface, Fe-Mn crust precipitation may have continued until the present.

At the most northerly guyot (Takuyo-Daisan), the seismic reflection profile reveals up to $60 \mathrm{~m}$ of pelagic sediments deposited in guyot surface depressions. Drilling in one of these depressions penetrated $18.4 \mathrm{~m}$ of the pelagic infill comprised of interlayered volcaniclastic sand, foraminiferal sand, nannofossil-foraminiferal sand, nannofossil-foraminiferal ooze and volcanic ash. Hole 880A did not reach the basement; thus, it remains unknown if $\mathrm{Fe}-\mathrm{Mn}$ crusts are present at this guyot. The penetrated pelagic deposits are Pliocene to late Pleistocene age. Pelagic carbonate, less than $2 \mathrm{~cm}$ thick, covers the surface of phosphatized shallow-water carbonate mounds located at the guyot periphery where Hole $879 \mathrm{~A}$ was located. The pelagic carbonate is 


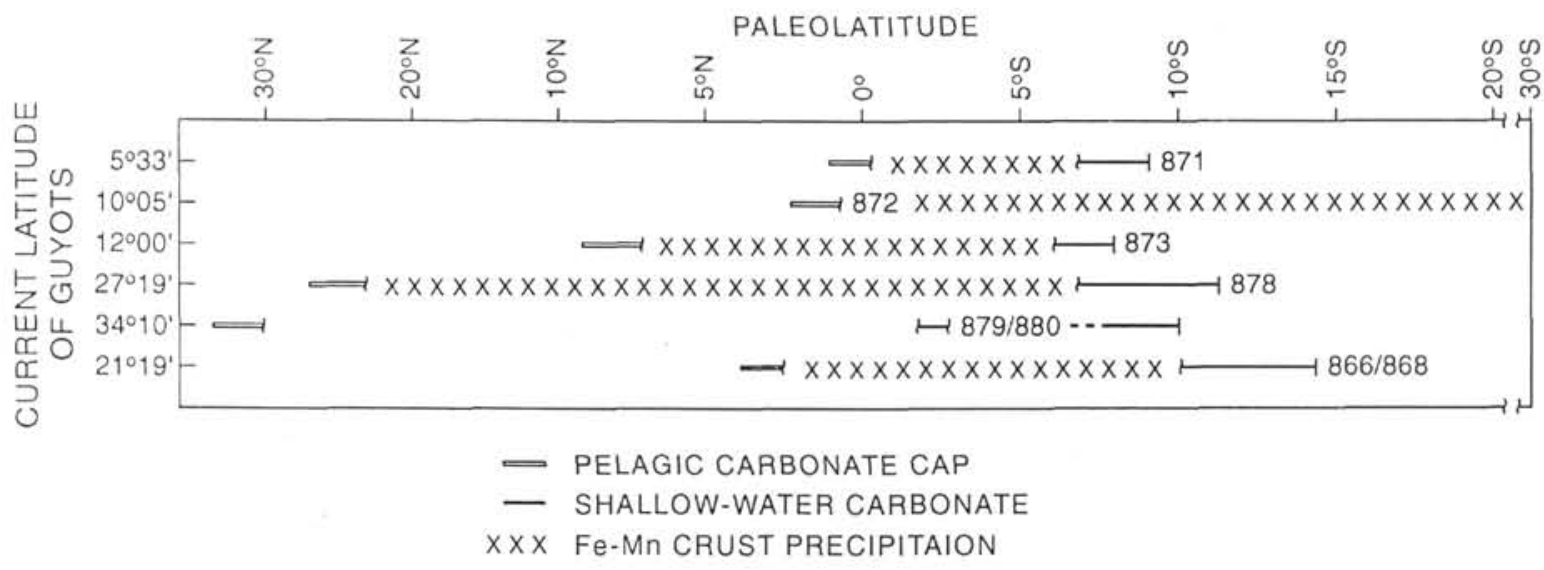

Figure 3. Paleolatitude of guyots during Fe-Mn crust precipitation. The figure demonstrates the paleolatitudinal dependency of the drowning of shallow-water carbonate platforms and the carbonate depositional hiatus during which Fe-Mn crust precipitated as well as the position of the guyots during pelagic carbonate cap deposition (constructed from data provided by R.L. Larson, pers. comm., 1993).

of late middle Eocene age (Premoli Silva, Haggerty, Rack, et al., 1993). The pelagic carbonate recovered at Hole $879 \mathrm{~A}$ lacks any FeMn encrustation.

\section{Occurrence and Morphology of Fe-Mn Crusts}

As mentioned above, the composition and structure of Fe-Mn crusts from the southern and northern group of guyots are different.

The southern guyots (Limalok, Lo-En, and Wodejebato guyots) have $\mathrm{Fe}-\mathrm{Mn}$ crusts that are morphologically variable and that were deposited on substrata of different compositions. At Limalok Guyot (Site 871) and Wodejebato Guyot (Sites 873-877), Fe-Mn oxyhydroxides encrust and permeate the top of a thin basal lag conglomerate, which overlies the surface of a drowned, shallow-water limestone. The pebbly bed is several centimeters thick and is composed of clasts of underlying shallow-water limestones with rare clasts of pelagic carbonate. At Limalok Guyot, the clasts of the conglomerate were phosphatized and coated by $<1$-mm-thick laminae of Fe-Mn oxyhydroxides, with thicker precipitates deposited in the space between limestone clasts. The conglomerate surface was then extensively bored, and a pelagic foraminiferal wackestone was then deposited in the burrows. Later, the pelagic carbonate infiltrated the cracks of the basal conglomerate. At Lo-En Guyot (Site 872), the crust coats an igneous pebble bed that overlies the igneous substratum and is reworked into the conglomerate (PI. 1, Fig. 4).

A detailed biostratigraphic study of the basal conglomerate at Limalok Guyot (Premoli Silva, Haggerty, Rack, et al., 1993) demonstrated that the shallow-water carbonate platform is of middle Eocene age, the pelagic carbonate that infills some of the borings in the Fe-Mn crust is of Oligocene age, and the base of the overlying pelagic carbonate cap is of early Miocene age. The deposition of Fe-Mn crust at this guyot thus occurred between middle Eocene and early Miocene.

Five sites were drilled on the summit of Wodejebato Guyot. Two holes at Site 873 sampled the central part of the guyot. Sites 874 and 877 were located on the bathymetric inner ridge at the northeastern periphery of the guyot. Sites 875 and 876 were located at the outer perimeter ridge. The Fe-Mn crust precipitation at Wodejebato Guyot shows a basic similarity to the processes observed at the Limalok Guyot. Crust precipitation followed deposition of a basal conglomerate and its phosphatization. However, at Wodejebato Guyot, the process of Fe-Mn crust deposition is much more complex, as is documented by Watkins et al. (this volume). Here, a thin ( $>1 \mathrm{~m}$ ) basal conglomerate bed overlies the top of a drowned Maastrichtian carbonate platform. Late Paleocene to middle Eocene pelagic carbonate infiltrates the intragranular space within the conglomerate, indicating at least three to four periods of bioerosion separated by multiple episodes of Fe-Mn crust formation and phosphatization. A televiewer survey of the surface of the guyot's periphery (where the pelagic carbonate blanket at places is only $10-400 \mathrm{~cm}$ thick) shows that the Fe-Mn crust covers the surface of the basal pebbly bed (Premoli Silva, Haggerty, Rack, et al., 1993). This upper crust recovered at Site 876 is $2-3 \mathrm{~cm}$ thick, dense, black, and of composite texture. Thinly laminated intervals 1 to $2 \mathrm{~mm}$ thick alternate with 1.5 - to 5 -mm-thick digitated laminae of botryoidal stacks of submillimeter hemispheres of Mn oxide dendrites (PI. 2, Fig. 1). The different structural layers of $\mathrm{Fe}-\mathrm{Mn}$ crusts have differing $\mathrm{Fe}-\mathrm{Mn}$ ratios (Table 2). An alternation of $\mathrm{Fe}-\mathrm{Mn}$ oxyhydroxides and phosphatic laminae is observed in the basal part of some of these crusts (Pl. 2, Fig. 2; Table 2).

The surface of the dense Fe-Mn crust at Wodejebato Guyot is coated by Mn oxide dendrites that occur as columns that are several $\mathrm{cm}$ in height and that extend upward into the foraminiferal limestone and impregnate both the matrix and fossils seemingly at random. The dendritic pattern of hydrated Mn-oxide is particularly striking in Sample 144-875C-1M-1, 7-14 cm, where it resembles a series of columnar stromatolites separated by pelagic limestone (Pl. 2, Fig. 3). The Mn dendrites cross-cut individual planktonic foraminfer tests, many of which are stained reddish yellow by a phosphate. Apatite crystals were found attached to the surface of the Fe-Mn oxyhydroxide crust (144-874B-1R-1, 7-10 cm; Pl. 2, Fig. 4). At Site 876, a film of Fe-Mn crust coats the phosphatized vertical surfaces of a solution pit that developed in the surface of the Wodejebato Guyot carbonate platform. A similar, dense, network of Mn oxide dendrites extends from the crust into the pelagic carbonate that infills the solution pit (fig. 9 in Premoli Silva, Haggerty, Rack, et al., 1993, p. 266).

Phosphatization has affected the older sedimentary deposits of the basal conglomerate at Wodejebato Guyot (Table 1). The pattern of phosphatization is not well constrained, but according to Watkins et al. (this volume) it appears probable that at least two episodes occurred: one during the late Paleocene and another during the early Eocene. The pelagic carbonate that overlies the Fe-Mn crust at Site 873 is of early Miocene age (Premoli Silva, Haggerty, Rack, et al., 1993).

At Lo-En Guyot, three holes were drilled about 100 to $150 \mathrm{~m}$ apart along a triangular perimeter. The weathered surface of the volcanic substrate is overlain by a pebbly conglomerate that is $21 \mathrm{~cm}$ thick and is composed of reworked basalt pebbles, composite conglomerate pebbles and millimeter- to centimeter-sized fragments of $\mathrm{Fe}-\mathrm{Mn}$ crust, all encased within early Campanian pelagic foraminiferal packstone (Premoli Silva, Haggerty, Rack, et al., 1993; Pl. 1, Fig. 4). Pebbles are up to $2 \mathrm{~cm}$ in diameter, some exhibiting a shiny, dark brown surface that is probably a thin film of Fe-Mn precipitate. The uppermost several millimeters of the pieces of broken Fe-Mn crust are finely laminated with $\mathrm{Mn}$ oxide dendrites covering the upper surface of 
Table 2. Chemical microanalyses (wt \%) from Fe-Mn crust at the Wodejebato Guyot (Sample 144-876A-1R-1, 35-36 cm).

\begin{tabular}{lrrrrrrr}
\hline & $\begin{array}{c}\text { Sample } \\
\text { no. }\end{array}$ & $\mathrm{Fe}$ & $\mathrm{Mn}$ & $\mathrm{Co}$ & $\mathrm{Ni}$ & $\mathrm{Cu}$ & $\mathrm{Zn}$ \\
\hline "Columnar" layer & 1 & 0.5 & 11.5 & 0.1 & 0.9 & 0 & 0.4 \\
& 2 & 0.5 & 5.7 & 0 & 0.5 & 0 & 0.3 \\
& 3 & 0.5 & 13.4 & 0.2 & 1.3 & 0 & 0.6 \\
& 4 & 0.6 & 4.0 & 0.1 & 0.3 & 0.1 & 0.4 \\
& 5 & 0.8 & 19.8 & 0.2 & 2.2 & 0.1 & 0.4 \\
& 6 & 1.1 & 4.9 & 0.3 & 0.1 & 0.1 & 0 \\
& 7 & 6.2 & 27.6 & 0.2 & 3.4 & 0.5 & 0.3 \\
Phosphate layer & 8 & 0.3 & 4.7 & 0.1 & 0.5 & 0 & 0.7 \\
Massive & 9 & 1.8 & 10.5 & 0.1 & 0.7 & 0.1 & 0.6 \\
$\quad$ ferromanganese & 11 & 1.0 & 0 & 0.1 & 0 & 0 & 0 \\
layer & & & 35.1 & 0 & 3.1 & 0.4 & 0.4 \\
& & & & & & & \\
\end{tabular}

Note: Location of laminae microsampled is shown in Plate 2, Figure 2. Sampling interval $2 \mathrm{~mm}$; sample no. 11 is the basal part of the crust. Calcium carbonate, which forms the rest of the major elements in the samples, is not shown.

the crust. The boundary between the crust and underlying lithified foraminiferal chalk is diffuse. A biostratigraphic study of the conglomerate indicates that there were at least two periods of Fe-Mn crust precipitation. The first period occurred in the early late Campanian and the late Paleocene and the second in the early Eocene (Watkins et al., this volume).

In the northern group of guyots (MIT and Takuyo-Daison guyots) Fe-Mn crusts and nodules were recovered only at MIT Guyot (Site 878). At Takuyo-Daison Guyot, no Fe-Mn crusts was encountered at the Site 879. However, the second drill site (Site 880 ) did not penetrate the pelagic cover; therefore, the presence or absence of Fe-Mn precipitates at this guyot is unknown.

Three holes were drilled at Site 878 offset by 14 and 20 m; thus only a small area of the MIT Guyot surface was investigated. The occurrence and texture of the Fe-Mn crusts at this site are very different from crusts seen at the southern guyots. MIT Guyot generally lacks a pelagic carbonate cover, with only remnants of it preserved in surface depressions. Hole $878 \mathrm{~A}$ was located in one of these depressions infilled by $3.2 \mathrm{~m}$ of pelagic carbonate. The yellowish-brown foraminiferal-nannofossil ooze of early late Pliocene to early Pleistocene age (Premoli Silva, Haggerty, Rack, et al., 1993) overlies the shallow-water carbonate platform of Albian age. Sand-to silt-sized Fe-Mn microconcretions of botryoidal morphology are dispersed throughout the pelagic sediment and impart a gritty texture to the ooze. Black, elliptical-shaped $\mathrm{Fe}-\mathrm{Mn}$ nodules (up to $5 \mathrm{~cm}$ diameter) float in the ooze; these are concentrated within the uppermost $30 \mathrm{~cm}$ of the ooze and then again at $70-95 \mathrm{~cm}$ (Pl. 1, Fig. 3). Most of the nodules have nuclei composed of strongly phosphatized limestone fragments. The surface of these limestone fragments, which are enclosed by Fe-Mn crusts, has a ragged outline that appears as if the Fe-Mn crust enveloped partially dissolved limestone fragments. A few nodules appear to be massive but are without an apparent nucleus. The surface of the underlying carbonate platform, which underlies the ooze at Hole 878A, lacks Fe-Mn precipitates. A different situation has been found nearby at Holes $878 \mathrm{~B}$ and $878 \mathrm{C}$, which were drilled on a slightly elevated plateau of the guyot. Here, the pelagic cover is missing and the carbonate platform surface is encrusted by a layer of Fe-Mn crusts and nodules $15-23 \mathrm{~cm}$ thick. Patches of phosphatized pelagic carbonate are attached to the nodules' surface. Thin sections of some of the nodules show at least five generations of pelagic carbonate infilling the nodules. They include shallow-water carbonate of late Albian age, which act as the nucleus of some of the nodules; late Santonian to early Campanian, early Eocene, and middle Eocene age pelagic carbonate infills the burrows within the $\mathrm{Fe}-\mathrm{Mn}$ crust (Watkins et al., this volume). This indicates that the oldest crusts are of pre-late Santonian-early Campanian age, with crust precipitation continuing intermittently at least into the Eocene. Because the crusts at the elevated surface of MIT Guyot are currently exposed to seawater, it is probable that Fe-Mn hydroxide precipitation could have continued until the present. Occurrences of older Fe-Mn nodules enclosed in the younger pelagic carbonate found in the depressions indicate that the $\mathrm{Fe}-\mathrm{Mn}$ nodules were occasionally transported from local bathymetric highs into the bathymetric lows, and thus accumulated in the younger pelagic sediment. However, differences in the mineralogical composition of the crusts between Holes $878 \mathrm{~A}$ and 878B (Table 3) argue against such a simple explanation.

Several preliminary conclusions can be derived from the stratigraphic position and morphology of the Fe-Mn crusts that accumulated atop the northwestern Pacific guyots. In the southern group of guyots, the crust precipitation followed the deposition of basal conglomerate, and continued after several episodes of reworking of the conglomerate. Pebbles in the conglomerate are about $2 \mathrm{~cm}$ in size, indicating a reworking by currents of about $100 \mathrm{~cm} / \mathrm{s}$ velocity, as derived from a modified Hjulstrom diagram (Friedman et al., 1992). The Fe-Mn oxyhydroxide encrusted surface of the basal conglomerate is overlain at every site by a well-sorted foraminifer ooze with tests from 0.1 to $0.25 \mathrm{~mm}$ in size. Such a foraminifer ooze would settle on the guyot surface at fluctuating current velocities of 1 to $38 \mathrm{~cm} / \mathrm{s}$ (flow condition calculated from sediment size after Bowen et al., 1984 and Syvitski and Schafer, in press).

The incorporation of older pelagic sediments within the Fe-Mn crusts and nodules and the presence of textural differences in the composition of the crusts indicate a prolonged period of crust formation. At MIT Guyot, the precipitation of crust may span a minimum of 60 m.y.; however, it may also have continued for 90 m.y. on hard surfaces of the guyot exposed to seawater.

Periods of Fe-Mn crust deposition at some of the southern group of guyots alternated with periods of Mn oxide precipitation, phosphatization, minor pelagic carbonate accumulation, and current-induced reworking during periods of increased current activity (Watkins et al., this volume). The Fe-Mn crusts, which occur mainly as precipitation rims around limestone clasts and/or semiconsolidated pelagic carbonate fragments, are predominantly $1-2 \mathrm{~cm}$ thick. Only rarely was a 5 -cm-thick crust sampled at the surface of a 25 -cm-thick nodule-crust bed. According to Halbach et al. (1982), younger crusts at the top of seamounts do not exceed $4 \mathrm{~cm}$, which is confirmed by our observations. Halbach et al. (1983) indicated growth rates of 0.2 $-2.7 \mathrm{~mm} / \mathrm{m}$.y. for crust from the central Pacific seamount province. Since most of the W-crusts sampled during Leg 144 are 1-2 $\mathrm{cm}$ thick and were deposited within 30 m.y. time window, the precipitation rate of these crusts is $0.66-1 \mathrm{~mm} / \mathrm{m}$.y., giving an average rate of $0.83 \mathrm{~mm} / \mathrm{m}$.y. M-crusts, which are up to $5 \mathrm{~cm}$ thick and deposited during a 30 - to 60 -m.y.period provide precipitation rate of $0.55-0.83 \mathrm{~mm} / \mathrm{m}$.y. with an average accretion rate of $0.69 \mathrm{~mm} / \mathrm{m}$.y. However, because interruption in crust precipitation as documented by Watkins et al. (this volume) occurred, these are average minimum accretion rates that include periods of nondeposition or erosion.

A generalized pattern of geologic processes that resulted in $\mathrm{Fe}-\mathrm{Mn}$ crust deposition at the guyots' surface and discussed in more detail in Jansa et al. (unpubl. data) is as follows:

1. drowning of the guyot surface, followed by a long period of nondeposition, initial intensive erosion of the substratum (carbonate platform or weathered volcanic pedestal), and redeposition of lithoclasts;

2. a period of phosphatization of carbonate deposits at some of the guyots when the top of the guyot subsided to about $400 \mathrm{~m}$ water depth as derived from guyot thermal subsidence curve after Parsons and Sclater (1977), and the projected initiation of ferromanganese crust precipitation as documented by micropaleontological analyses of sedimentary deposits underlying the crust and enclosed by the crust (Premoli Silva, Haggerty, Rack, et al., 1993; Fig. 3);

3. precipitation of iron and manganese oxyhydroxides when current velocities over the guyot surface were approximately $<38 \mathrm{~cm} / \mathrm{s}$, thus sweeping clean pelagic carbonate deposits from the guyot surface; 
4. pelagic carbonate deposits buried Fe-Mn crusts at the southern group of guyots when the top of the guyot subsided to water depth of $\sim 850-1050 \mathrm{~m}$ (Fig. 3). The current velocities at this depth in the present equatorial Pacific are below $\sim 30 \mathrm{~cm} / \mathrm{s}$ (Tomszak and Godfrey, 1994), and closely corresponds to our calculated current velocity of less than $\sim 38 \mathrm{~cm} / \mathrm{s}$ from pelagic sediments deposited at the top of these guyots.

\section{MINERALOGY AND CRYSTAL CHEMISTRY OF FERROMANGANESE DEPOSITS}

The mineralogy of Leg 144 crusts is highly variable (Table 3). The morphology of the oxide minerals was determined by scanning electron microscopy (SEM). Vernadite and Mn-ferroxyhyte pseudolayering is characterized by fine-scaly aggregates ( $\mathrm{Pl}$. 3), birnessite layering by individual lamellae (Pl. 4), and tunnel todorokite by double and triple accretions with differing degrees of structural arrangement (Pl. 5). Fine lamellae of microcrystals characterize Niasbolane. Double-space continuous octahedral layers of $\mathrm{Mn}^{4+}$ and broken octahedral layers of Ni regularly alternate in the structure of the latter mineral (Tchuchrov et al., 1989; Gorshkov et al., in press; Pl. 6). Black lines represent $\mathrm{Mn}^{4+}$ octahedral layers, and gray lines indicate broken $\mathrm{Ni}$ octahedral layers. The spacing between layers of similar composition is $9.3 \AA$. Mixed layers of asbolane-buserite with an irregular alternation of asbolane and buserite packages (Tchuchrov et al., 1989) shows as fine-scaly aggregates. The ferroxyhyte phase present in some of the samples from the MIT Guyot (Table 3 ) forms similar aggregates. A structural model of the ferroxyhyte phase has not yet been constructed (Tchuchrov et al., 1989), although the presence of this mineral has been confirmed by X-ray diffraction.

Samples of Fe-Mn crusts were available for mineralogical and chemical analyses only from the Wodejebato and MIT guyots. Hereafter those taken from the Wodejebato Guyot are referred to as W-crusts and those from MIT Guyot as M-crusts.

Mineralogical analyses of Fe-Mn crusts from the northwestern Pacific guyots show the presence of two mineralogical assemblages. The asbolane-buserite assemblage is dominant in M-crusts, but also occurs as a minor component in W-crusts (Site 873). This assemblage is not usually present in seamount crusts, but it is typical for deep-sea, diagenetically formed ferromanganese nodules. It forms in suboxic environments, in contrast to the oxidizing conditions that are required for hydrogenetic Mn-mineral precipitation. The asbolane-buserite appears to be one of the main concentrators of Ni. Birnessite co-occurs with the above minerals, and is typical of diagenetically formed nodules. Vernadite rarely occurs in this mineral assemblage.

The second mineral assemblage is dominated by Fe-vernadite and is predominantly found in W-crusts (Site 874); however, it is also present as a minor component in M-crusts (Site 878). Vernadite is frequently the dominant $\mathrm{Mn}$-mineral phase of hydrogenetic ferromanganese deposits and appears to be a mineral typical of seamount crusts and nodules (Hein et al., 1985, 1992; Kang, 1987; Tchuchrov et al., 1989; Gorshkov et al., 1991). The presence of the ferroxyhyte phase in some of the crusts from Site 878 co-occurring with vernadite supports the proposed hydrogenetic mode of precipitation of these Fe-Mn crusts. Asbolane-buserite, birnessite, and apparently todorokite, which occur together with vernadite in some of the M-crusts, indicate a variability of depositional conditions during crust precipitation.

The transitional nature of the environmental conditions between the southern and northern group of guyots is reflected at Wodejebato Guyot by the mineralogical composition of the Fe-Mn crusts. A dominance of the asbolane-buserite assemblage was identified in W-crusts (Sites 873 and 876) and in some of the M-crusts (Site 878). In contrast, W-crusts at Site 874 and M-crusts at Site 878 are dominated by Fe-vernadite. Thus, both mineralogical assemblages are present at both guyots, but only one is dominant. The presence of crusts of different mineralogical and chemical composition within a single guyot documents the complexity of Fe-Mn oxyhydroxide pre-
Table 3. Mineralogical composition of Fe-Mn crusts and nodules, Leg 144.

\begin{tabular}{|c|c|c|}
\hline $\begin{array}{l}\text { Core, section, } \\
\text { interval }(\mathrm{cm})\end{array}$ & $\begin{array}{l}\text { Sample } \\
\text { no. }\end{array}$ & Mineral composition \\
\hline \multicolumn{3}{|c|}{ Southern group of guyots (Wodejebato Guyot, W-crusts): } \\
\hline $\begin{array}{l}144-873 A- \\
\text { IR-1,0-7 } \\
\text { IR-1,0-7 } \\
\text { IR-1,0-7 } \\
\text { IR-1,0-7 } \\
\text { IR-1, 10-13 } \\
2 \mathrm{R}-1,0-5\end{array}$ & $\begin{array}{l}1 \\
2 \\
3 \\
4\end{array}$ & $\begin{array}{l}\text { Asb-Bus + MFE-Ver + Ni-Bir (rare) } \\
\text { Asb-Bus + Ni-Asb + MFe-Bir + Ni-Bir (minor) } \\
\text { Asb-Bus + Ni-Asb + MFe-Ver + Ni-Bir (minor) } \\
\text { Asb-Bus + Ni-Asb + MFe-Ver + Ni-Bir (minor) } \\
\text { Asb-Bus + Ni-Asb + Fe-Ver (minor) + Ni-Bir (minor) } \\
\text { Fe-Ver + Mn-Fer (minor) + Asb-Bus (minor) }\end{array}$ \\
\hline $\begin{array}{l}144-873- \\
1 \mathrm{R}-1,16-20 \\
7 \mathrm{H}-\mathrm{CC}, 0-1 \\
8 \mathrm{~N}-1,0-3 \\
8 \mathrm{~N}-1,4-7\end{array}$ & & $\begin{array}{l}\text { Fe-Ver + Asb-Bus (minor) } \\
\text { Asb-Bus + Fe-Ver } \\
\text { Fe-Ver + Asb-Bus } \\
\text { Asb-Bus + Fe-Ver + Ni-Bir (rare) }\end{array}$ \\
\hline $\begin{array}{l}144-874 A- \\
\text { IR-1,0-3 } \\
\text { IR-1,3-6 } \\
\text { IR-1,7-3 }\end{array}$ & & $\begin{array}{l}\text { Fe-Ver } \\
\text { Fe-Ver } \\
\text { Fe-Ver }\end{array}$ \\
\hline $\begin{array}{l}\text { 144-874B- } \\
\text { IR-1,0-6 } \\
\text { IR-1, 7-10 }\end{array}$ & 1 & $\begin{array}{l}\text { Fe-Ver + Asb-Bus (minor) } \\
\text { Fe-Ver + Mn-Fer (minor) }+ \text { Asb-Bus (minor) }\end{array}$ \\
\hline $\begin{array}{l}\text { 144-876A- } \\
\text { IR-1,0-4 } \\
\text { IR-1, 12-17 } \\
\text { IR-1,17-22 } \\
\text { IR-1,35-36 }\end{array}$ & & $\begin{array}{l}\mathrm{Fe}-\mathrm{Ver}+\mathrm{Asb}-\mathrm{Bus} \text { (minor) } \\
\mathrm{Mn}-\mathrm{Fer}+\mathrm{Fe}-\mathrm{Ver}+\mathrm{Asb}-\mathrm{Bus} \text { (minor) } \\
\text { Asb-Bus + Mn-Fer + Fe-Ver (minor) + Tod (minor) } \\
\text { Asb-Bus + Mn-Fer + Fe-Ver + Ni-Bir (minor) }\end{array}$ \\
\hline \multicolumn{3}{|c|}{ Northern group of guyots (MIT Guyot, M-crusts and nodules): } \\
\hline $\begin{array}{l}144-878 \mathrm{~A}- \\
\text { IR-1, 32-35 } \\
\text { IR-1,87-88 } \\
\text { 47R-1, 0-5 }\end{array}$ & 1 & $\begin{array}{l}\mathrm{Ni}-\mathrm{Bir}+\mathrm{Asb}-\mathrm{Bus}(\text { minor })+\mathrm{Fe}-\mathrm{Ver}(\text { minor }) \\
\text { Fe-Ver + Asb-Bus (minor) + Mn-Fer (minor) } \\
\text { Fe-Ver }\end{array}$ \\
\hline $\begin{array}{l}\text { 144-878B- } \\
\text { IR-1,5-7 } \\
\text { IR-1,12-14 }\end{array}$ & & $\begin{array}{l}\text { Asb-Bus + Fe-Ver (minor) } \\
\text { Asb-Bus + Fe-Ver + Tod (minor) + Mn-Fer (minor) + Fe- } x \\
\text { phase (minor) }\end{array}$ \\
\hline IR-1, 0-10 & & Asb-Bus $+\mathrm{Fe}-\mathrm{Ver}+\mathrm{Mn}-\mathrm{Fer}$ (minor) $+\mathrm{Fe}-\mathrm{x}$ phase (minor) \\
\hline $\begin{array}{l}144-878 \mathrm{C}- \\
1 \mathrm{R}-1,0-5 \\
\operatorname{IR}-1,18-23\end{array}$ & & $\begin{array}{l}\mathrm{Fe}-\mathrm{Ver} \\
\text { Asb-Bus + Fe-Ver + Ni-Bir (minor) }\end{array}$ \\
\hline
\end{tabular}

Note: $\mathrm{Fe}-\mathrm{Ver}=\mathrm{Fe}$-vernadite, $\mathrm{MFe}-\mathrm{Ver}=$ lower-iron vernadite, $\mathrm{Mn}-\mathrm{Fer}=\mathrm{Mn}$-feroxyhyte, $\mathrm{Asb}=$ asbolane, $\mathrm{Asb}-\mathrm{Bus}=$ asbolane-buserite, and $\mathrm{Bir}=$ birnessite.

cipitation on seamount surfaces. This implies that the results obtained from a single sample, or from a single location on the seamount, should not be considered fully representative of the dominant processes affecting the seamount.

\section{CHEMISTRY OF FERROMANGANESE DEPOSITS}

Iron, manganese, silica, aluminum, and in some samples, calcium and phosphate, are the main chemical components of the studied Fe-Mn crusts (Table 4). The mean content of iron and manganese is $7.1 \%$ and $14.4 \%$, respectively, which is slightly lower than is the metal content of deep-sea nodules and Pacific crusts (Table 5). The mean Fe-Mn ratio of 0.49 (with a range from 0.24 to 1.18 ) is also slightly lower than in other hydrogenetic ferromanganese deposits. Only minor amounts of lithogenic elements $(\mathrm{Al}$ and $\mathrm{Si})$ were measured in the northwestern Pacific guyot crusts. The $\mathrm{Si} / \mathrm{Al}$ ratio of 4.4 is similar to the ratio found in pelagic sediments in which terrigenous aluminosilicates are the main carriers of $\mathrm{Al}$ and $\mathrm{Si}$.

The triangular diagram of $\mathrm{Fe}-\mathrm{Mn}$ - $\mathrm{Al}$ content of the ferromanganese deposits (Fig. 4) defines two fields that correspond to the southern and northern guyot groupings. W-crusts are characterized by increased calcium carbonate and phosphate content and are less enriched in aluminum and silica than the M-crusts. Other minor and trace elements in ferromanganese deposits such as $\mathrm{Ti}, \mathrm{Co}, \mathrm{La}, \mathrm{Nd}, \mathrm{Sm}, \mathrm{Ce}$, and others listed in Tables 4 and 7 do not form their own mineral phases, but are scavenged from seawater mainly by ferromanganese oxides (Elderfield and Greaves, 1982; De Carlo and McMurtry, 1992). 
Table 4. Chemical composition of Fe-Mn crusts and nodules, Leg 144.

\begin{tabular}{|c|c|c|c|c|c|c|c|c|c|c|c|c|c|c|c|}
\hline $\begin{array}{l}\text { Core, section, } \\
\text { interval }(\mathrm{cm})\end{array}$ & $\begin{array}{c}\text { Sample } \\
\text { no. }\end{array}$ & $\begin{array}{l}\mathrm{Fe} \\
(\%)\end{array}$ & $\begin{array}{l}\mathrm{Mn} \\
(\%)\end{array}$ & $\begin{array}{l}\text { Co } \\
(\%)\end{array}$ & $\begin{array}{l}\mathrm{Ni} \\
(\%)\end{array}$ & $\begin{array}{c}\mathrm{Cu} \\
(\mathrm{ppm})\end{array}$ & $\begin{array}{c}\mathrm{Zn} \\
(\mathrm{ppm})\end{array}$ & $\begin{array}{l}\mathrm{Pb} \\
(\%)\end{array}$ & $\begin{array}{c}\mathrm{Si} \\
(\%)\end{array}$ & $\begin{array}{l}\mathrm{Al} \\
(\%)\end{array}$ & $\begin{array}{l}\mathrm{Ti} \\
(\%)\end{array}$ & $\begin{array}{c}\mathrm{V} \\
(\mathrm{ppm})\end{array}$ & $\begin{array}{l}P \\
(\%)\end{array}$ & $\begin{array}{c}\mathrm{CaCo}_{3} \\
(\%)\end{array}$ & $\begin{array}{l}\mathrm{C}_{\text {org }} \\
(\%)\end{array}$ \\
\hline \multicolumn{16}{|l|}{$144-873 \mathrm{~A}-$} \\
\hline IR-1, 0-7 & 2 & 3.92 & 13.60 & 0.19 & 1.40 & 1820 & 1350 & 400 & 0.40 & 0.24 & 0.23 & 190 & 6.90 & 8.2 & 0.15 \\
\hline IR-1,0-7 & 3 & 4.32 & 14.60 & 0.22 & 1.03 & 1150 & 1030 & 580 & 0.12 & 0.05 & 0.25 & 280 & 7.10 & 6.7 & 0.14 \\
\hline IR-1, 10-I3 & & 1.79 & 5.50 & 0.09 & 0.85 & 1090 & 730 & 220 & 0.12 & 0.05 & 0.12 & 80 & 9.30 & 24.7 & 0.20 \\
\hline IR-1, 13-I6 & & 5.59 & 10.20 & 0.17 & 0.88 & 970 & 950 & 440 & 0.24 & 0.03 & 0.28 & 180 & 8.10 & 6.3 & 0.38 \\
\hline $2 R-1,0-5$ & & 7.57 & 18.60 & 0.24 & 0.54 & 1020 & 700 & 1050 & 0.59 & $<0.03$ & 0.4 & 470 & 4.20 & 4.5 & 0.11 \\
\hline \multicolumn{16}{|l|}{ 144-873B- } \\
\hline 7H-CC, $0-1$ & & 5.20 & 12.30 & 0.17 & 1.25 & 2730 & 1000 & 340 & 0.82 & 0.36 & 0.3 & 260 & 6.40 & 10.8 & 0.11 \\
\hline $8 \mathrm{~N}-1,0-3$ & & 6.95 & 19.00 & 0.23 & 0.94 & 870 & 1210 & 700 & 0.45 & 0.05 & 0.4 & 460 & 4.70 & 4.7 & 0.10 \\
\hline $8 \mathrm{~N}-1,4-7$ & & 5.92 & 12.20 & 0.14 & 1.01 & 1810 & 1210 & 350 & 0.82 & 0.17 & 0.3 & 240 & 7.40 & 7.6 & 0.16 \\
\hline \multicolumn{16}{|l|}{ 144-874A- } \\
\hline IR-1, 0-3 & & 7.93 & 17.30 & 0.40 & 0.60 & 610 & 780 & 750 & 0.59 & 0.10 & 0.42 & 410 & 4.80 & 3.5 & 0.12 \\
\hline IR-1, 3-6 & & 6.65 & 15.40 & 0.22 & 0.47 & 250 & 730 & 820 & 0.68 & 0.07 & 0.39 & 330 & 5.40 & 4.6 & 0.10 \\
\hline IR-7, 7-13 & & 7.53 & 13.70 & 0.19 & 0.54 & 400 & 890 & 900 & 0.61 & 0.07 & 0.38 & 280 & 5.90 & 5.7 & 0.12 \\
\hline \multicolumn{16}{|l|}{ 144-874B- } \\
\hline IR-1, 0-6 & 1 & 5.64 & 18.40 & 0.27 & 0.66 & 700 & 950 & 850 & 0.80 & 0.15 & 0.38 & 400 & 4.60 & 5.3 & 0.10 \\
\hline IR-1, 0-6 & 2 & 1.98 & 2.40 & 0.04 & 0.27 & 240 & 300 & 150 & 0.75 & 0.05 & 0.12 & 70 & 7.20 & 45.9 & 0.14 \\
\hline IR-I, 7-10 & & 8.83 & 11.70 & 0.15 & 0.27 & 240 & 550 & 910 & 0.96 & 0.10 & 0.46 & 310 & 5.80 & 15.6 & 0.07 \\
\hline \multicolumn{16}{|l|}{ 144-876A- } \\
\hline IR-1, 0-4 & & 6.51 & 20.00 & 0.43 & 0.87 & 780 & 1160 & 870 & 0.42 & $<0.03$ & 0.38 & 420 & 4.40 & 3.8 & 0.07 \\
\hline IR-1, 4-8 & & 9.33 & 13.90 & 0.20 & 0.40 & 530 & 720 & 1130 & 0.63 & 0.05 & 0.38 & 330 & 5.10 & 10.0 & 0.06 \\
\hline IR-1, 12-17 & & 9.54 & 11.90 & 0.16 & 0.40 & 670 & 810 & 1030 & 0.85 & 0.17 & 0.38 & 320 & 6.90 & 9.4 & 0.11 \\
\hline IR-1, 35-36 & & 1.23 & 5.10 & 0.07 & 0.55 & 600 & 640 & 310 & 0.19 & 0.07 & 0.09 & 120 & 9.40 & 2.9 & 0.15 \\
\hline \multicolumn{16}{|l|}{$144-877 \mathrm{~A}-$} \\
\hline R-1, 0-4 & & 7.31 & 20.40 & 0.29 & 0.60 & 310 & 830 & 1080 & 0.59 & $<0.03$ & 0.41 & 430 & 4.20 & 3.6 & 0.08 \\
\hline \multicolumn{16}{|l|}{ 144-878A- } \\
\hline IR-1, 0-90 & & 5.77 & 4.90 & 0.16 & 0.17 & 400 & 260 & 510 & 3.00 & 0.56 & 0.29 & 150 & 10.20 & 7.9 & 0.17 \\
\hline IR-1, 32-35 & & 10.01 & 27.70 & 0.52 & 0.51 & 1020 & 720 & 1490 & 2.20 & 0.81 & 0.75 & 730 & 0.51 & 1.3 & 0.09 \\
\hline IR-1, 87-88 & & 14.89 & 18.00 & 0.73 & 0.46 & 1060 & 840 & 1830 & 3.80 & 1.36 & 0.92 & 430 & 1.90 & 2.4 & 0.13 \\
\hline $47 \mathrm{R}-1,0-5$ & 1 & 4.60 & 6.00 & 0.11 & 0.20 & 410 & 100 & 480 & 2.00 & 0.25 & 0.29 & 150 & 9.90 & 5.6 & 0.14 \\
\hline $47 \mathrm{R}-1,0-5$ & 2 & 4.73 & 5.60 & 0.10 & 0.22 & 370 & 260 & 360 & 1.90 & 0.23 & 0.27 & 130 & 10.20 & 5.6 & 0.14 \\
\hline $47 \mathrm{R}-1,0-5$ & 3 & 6.03 & 7.80 & 0.14 & 0.25 & 500 & 210 & 570 & 2.20 & 0.36 & 0.36 & 210 & 9.50 & 4.9 & 0.16 \\
\hline $47 \mathrm{R}-1,0-5$ & 4 & 7.39 & 9.20 & 0.16 & 0.27 & 460 & 430 & 690 & 2.30 & 0.36 & 0.42 & 220 & 8.30 & 4.4 & 0.14 \\
\hline \multicolumn{16}{|l|}{ 144-878B- } \\
\hline IR-1, 5-7 & & 15.08 & 19.00 & 0.63 & 0.60 & 710 & 690 & 1660 & 4.10 & 1.26 & 0.78 & 490 & 1.30 & 2.2 & 0.11 \\
\hline IR-1, 12-14 & & 10.30 & 31.10 & 0.64 & 0.49 & 990 & 550 & 1260 & 2.90 & 1.11 & 0.63 & 490 & 0.33 & 1.8 & 0.06 \\
\hline \multicolumn{16}{|l|}{ 144-878C. } \\
\hline $1 \mathrm{R}-1,0-5$ & & 11.76 & 21.50 & 0.47 & 0.55 & 1070 & 800 & 1270 & 3.20 & 0.83 & 0.73 & 520 & 2.20 & 1.9 & 0.07 \\
\hline IR-1, 18-23 & & 8.23 & 24.70 & 0.34 & 0.79 & 1110 & 910 & 1110 & 2.90 & 0.86 & 0.56 & 540 & 2.10 & 1.7 & 0.06 \\
\hline
\end{tabular}

Table 5. Average chemical composition of Fe-Mn crusts and nodules from the northwestern Pacific guyots, Leg 144, compared to other Pacific crusts and nodules.

\begin{tabular}{|c|c|c|c|c|c|c|c|c|c|}
\hline & \multirow{2}{*}{$\begin{array}{l}\text { Samples } \\
(N)\end{array}$} & \multicolumn{8}{|c|}{ Elements (wt\%) } \\
\hline & & $\mathrm{Fe}$ & Mn & $\mathrm{Co}$ & $\mathrm{Ni}$ & $\mathrm{Cu}$ & $\mathrm{Zn}$ & $\mathrm{Pb}$ & $\mathrm{Si}$ \\
\hline All samples & 30 & 7.1 & 14.4 & 0.26 & 0.6 & 0.08 & 0.07 & 0.08 & 1.4 \\
\hline \multicolumn{10}{|l|}{ Crust type: } \\
\hline W-crust & 19 & 6.0 & 13.5 & 0.20 & 0.71 & 0.09 & 0.06 & 0.07 & 0.56 \\
\hline M-crust & 11 & 9.0 & 16.0 & 0.36 & 0.41 & 0.07 & 0.05 & 0.10 & 2.80 \\
\hline Without anomalous samples & 6 & 11.7 & 23.7 & 0.56 & 0.57 & 0.10 & 0.07 & 0.14 & 3.20 \\
\hline Marshall Islands crusts* & $55-63$ & 13.0 & 21.0 & 0.74 & 0.45 & 0.08 & - & 0.14 & 2.10 \\
\hline Average central Pacific crusts* & $34-167$ & 15.0 & 22.0 & 0.78 & 0.44 & 0.08 & - & 0.16 & 3.00 \\
\hline Average Pacific hydrogenous crusts* & $56-319$ & 15.0 & 22.0 & 0.63 & 0.44 & 0.08 & - & 0.16 & 5.20 \\
\hline \multirow[t]{3}{*}{ Average Pacific deep-sea nodules** } & - & 12.4 & 18.4 & 0.29 & 0.67 & 0.43 & 0.84 & 0.11 & 8.27 \\
\hline & \multicolumn{9}{|c|}{ Elements (wt\%) } \\
\hline & $\mathrm{Al}$ & $\mathrm{Ti}$ & V & $\mathrm{P}$ & $\mathrm{C}_{\text {org }}$ & $\mathrm{CaCO}_{3}$ & $\mathrm{Fe} / \mathrm{Mn}$ & $\mathrm{Si} / \mathrm{Al}$ & \\
\hline All samples & 0.32 & 0.39 & 0.03 & 5.6 & 0.12 & 7.4 & 0.49 & 4.4 & \\
\hline \multicolumn{10}{|l|}{ Crust type: } \\
\hline W-crust & 0.09 & 0.32 & 0.03 & 6.2 & 0.13 & 9.7 & 0.44 & 6.2 & \\
\hline M-crust & 0.73 & 0.51 & 0.04 & 3.6 & 0.12 & 3.6 & 0.56 & 3.8 & \\
\hline Without anomalous samples & 1.00 & 0.73 & 0.05 & 1.9 & 0.09 & 1.9 & 0.49 & 3.2 & \\
\hline Marshall Islands crusts* & - & 0.90 & - & 0.66 & - & - & 0.61 & - & \\
\hline Average central Pacific crusts* & - & 1.10 & - & 0.66 & - & - & 0.71 & - & \\
\hline Average Pacific hydrogenous crusts* & - & 0.98 & - & 0.48 & - & - & 0.81 & - & \\
\hline Average Pacific deep-sea nodules** & 3.27 & 0.80 & 0.06 & - & - & - & 0.67 & 2.5 & \\
\hline
\end{tabular}

Notes: Single asterisk $\left(^{*}\right)=$ data from Hein et al. (1992). Double asterisks (**) = values for Fe, Mn, Ni, Co, and Cu from Anikeeva et al. (1984). Values for other elements from Volkov (1979). $N=$ number of samples. 

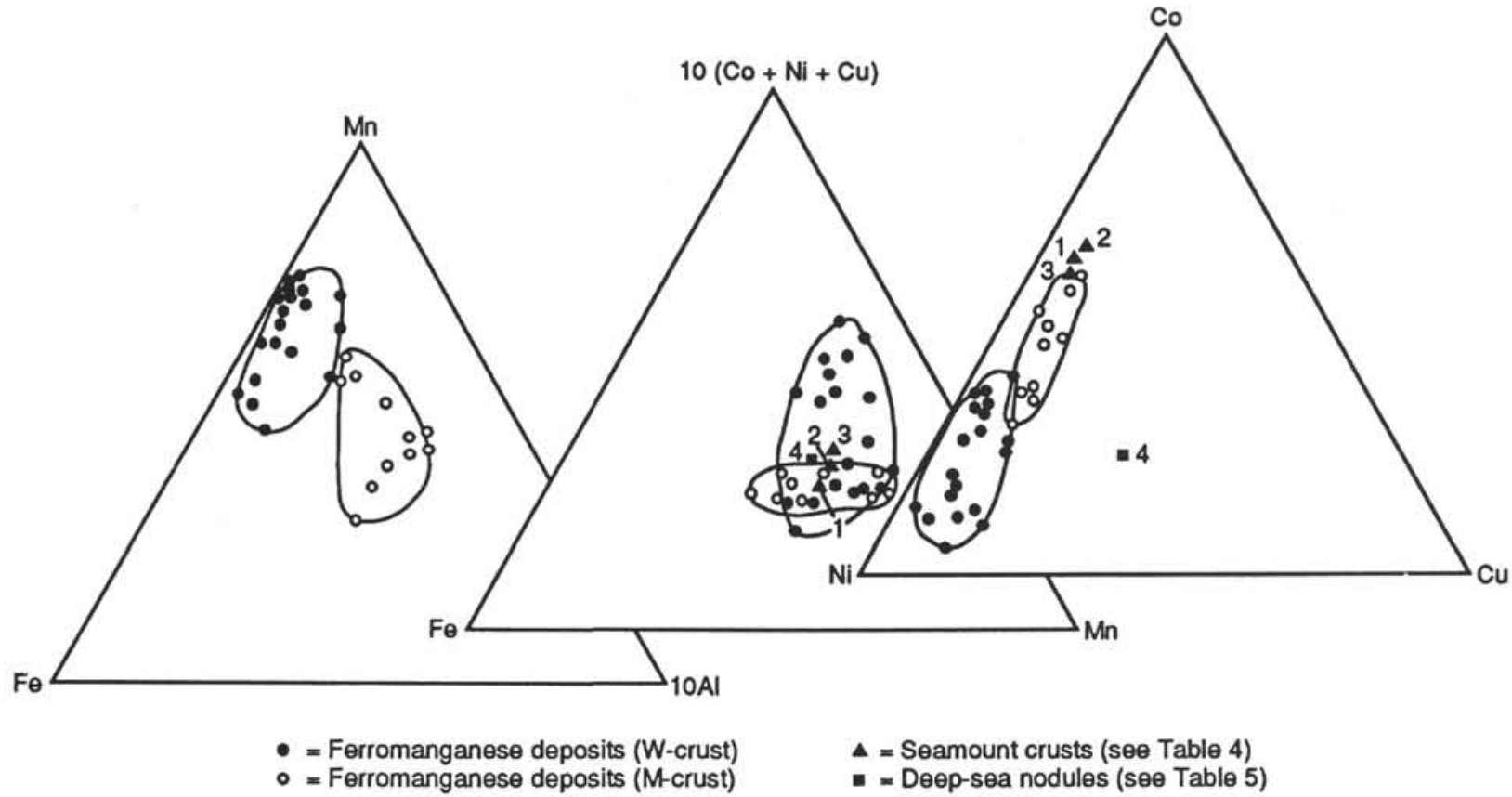

Figure 4. Triangular diagrams for minor elements (Fe-Mn-10Al) and trace elements $[(10 \mathrm{Co}+\mathrm{Ni}+\mathrm{Cu})-\mathrm{Fe}-\mathrm{Mn} ; \mathrm{Co}-\mathrm{Ni}-\mathrm{Cu})]$ in $\mathrm{Leg} 144 \mathrm{ferromanganese}$ crusts and nodules and an average for seamount crusts and deep-sea nodules (data and their sources are given in Table 5). $1=$ Marshall Island crusts, $2=$ average central Pacific crusts, 3 = average Pacific hydrogenous crusts, and 4 = average Pacific deep-sea nodules.

The plot of the concentrations of $\mathrm{Co}, \mathrm{Ni}$, and $\mathrm{Cu}$ (Fig. 4) separates the Fe-Mn crusts from the southern and northern group of guyots. The M-crusts are enriched in Co in comparison with the W-crusts, which show a slight enrichment in $\mathrm{Ni}$ (Table 4). Crusts from both of these groups differ from deep-sea nodules by a much lower content of $\mathrm{Cu}$ (Fig. 4). As Figure 4 shows, the M-crust composition is similar to FeMn crusts from other seamounts. The M- and W-crusts can be also separated by differences in $\mathrm{Co} / \mathrm{Ni}$ ratio, but not by their $\mathrm{Fe} / \mathrm{Mn}$ ratio (Fig. $5 \mathrm{~A}$ ).

On the $\mathrm{Co}-\mathrm{Cu}-\mathrm{Zn}$ diagram (Fig. 5B), M-crusts plot into a field characterized by $\mathrm{Co}$ enrichment in comparison to the W-crusts, which show $\mathrm{Cu}$ and $\mathrm{Zn}$ enrichment. The enrichment in $\mathrm{Cu}$ and $\mathrm{Zn}$ in W-crusts may indicate a source of metals derived from an active uptake by organisms ( $\mathrm{Zn}$ is used in the enzyme system of some living organisms; Millero and Sohn, 1992) and by a passive uptake ( $\mathrm{Cu}$ is adsorbed on particulate organic matter; ibid). Thus, the enrichment of both metals could be explained by an increase in both living and dead organic matter and, therefore, by an increase of biomass productivity during W-crust precipitation.

A correlation coefficient matrix (Table 6) and factor analysis (Fig. 6A-B) further elucidate the association of elements within the two types of crusts. Four factors $(44 \%, 26 \%, 12 \%$, and $7 \%$ of variance, respectively) were applied to $\mathrm{W}$-crusts. Factor 1 documents a strong correlation between $\mathrm{Fe}, \mathrm{Mn}, \mathrm{Co}, \mathrm{Pb}, \mathrm{Ti}$, and $\mathrm{V}$ and a negative correlation with $\mathrm{P}, \mathrm{CaCO}_{3}$, and $\mathrm{C}_{\mathrm{org}}$. Factor 2 combines $\mathrm{Ni}, \mathrm{Cu}, \mathrm{Zn}$, and $\mathrm{Al}$. The first three elements in Factor 2 are manganophiles, but the absence of $\mathrm{Mn}$ in the group suggests that this group of elements probably reflects an increased concentration of nutrients in seawater. $\mathrm{Al}$ is found in the group without $\mathrm{Si}$ : this may be attributed to absorption of the element from seawater by the organic matter (Murray et al., 1993). Considerable fluctuations of the $\mathrm{Si} / \mathrm{Al}$ ratio in the composition of the crust testifies to the possible multiple sources of these elements (e.g., terrigenous particles and absorbed element on the organic matter). Factor 3 delineates two groups with a strong negative correlation: $\mathrm{Si}$ and $\mathrm{Al}$ (indicators of lithogenic material), and $\mathrm{C}_{\text {org. }}$. Factor 4 suggests poor correlation between $\mathrm{C}_{\text {org }}$ and $\mathrm{Fe}$.

Four factors $(78 \%, 12 \%, 4 \%$, and $3 \%$ of variance, respectively) were applied on M-crusts. Elements possess acceptable factor loadings only for the first two factors. Factor 1 defines the same two groups of elements as established by factor analyses for W-crusts, except with the addition of $\mathrm{Ni}$ and $\mathrm{Cu}$ to the group including $\mathrm{Mn}$ and $\mathrm{Fe}$. This factor also has a stronger loading for both $\mathrm{Al}$ and $\mathrm{Zn}$ as compared to Factor 1 for the W-crusts. Factor 2 reveals a weak correlation between $\mathrm{Si}, \mathrm{C}_{\text {org }}, \mathrm{Fe}$, and $\mathrm{Al}$. The presence of $\mathrm{Si}$ and $\mathrm{Al}$ suggests a terrigenous particle contribution.

\section{Rare Earth Elements}

The concentration of rare earth elements (REE) was determined in 20 samples of crusts and nodules ( 13 samples from Wodejebato Guyot and seven samples from MIT Guyot; Table 7). Shale-normalized REE patterns for all samples show a positive Ce anomaly typical of Fe-Mn ocean deposits (Aplin, 1984; De Carlo, 1991), with an exception of four samples from W-crusts. Two of these (Samples 144-873A-1R-1, 0-7 cm, and -1R-1, 13-16 cm; Fig. 7A) have a REE pattern similar to that of oceanic waters (Klinkhammer et al., 1983; De Baar et al., 1985a, 1985 b), although they are highly enriched in all REE relative to shale. The other two exceptions (Samples 144-874B-1R-1, 0-6 cm, and 144-876A-1R-1, 35-36 cm; Fig. 7B) are from crust comprised mainly of phosphate and are depleted in Ce relative to shale, with values normalized to shale as low as 0.4 . Such low concentrations are characteristic of the North Pacific Fe-Mn nodules (Fig. 7C; Elderfield and Greaves, 1981). Examination of the cerium concentration in anoxic waters (Elderfield, 1988) reveals that, whereas oxic water is supersaturated with $\mathrm{Ce}$, anoxic seawater is considerably undersaturated. Hence, the Ce content in Fe-Mn crusts may be a useful tracer of past oceanic redox conditions as suggested by De Carlo (1991). Enrichment of Ce in natural $\mathrm{Fe}-\mathrm{Mn}$ deposits has been attributed to oxidative scavenging of $\mathrm{Ce}^{3+}$ at the $\mathrm{MnO}_{2}$ surface (Goldberg, 1963) and has been experimentally confirmed by Koeppenkastrop and De Carlo (1992). The intrinsic relationship between $\mathrm{Ce}$ and $\mathrm{Mn}$ is supported by our data which shows covariation between these two elements in Fe-Mn crusts (Table 8). The observed very low concentration of $\mathrm{Ce}$ in the phosphate phase of the crusts suggests an inverse relation between $\mathrm{P}$ and $\mathrm{Ce}$.

The analyzed Fe-Mn crusts are enriched in La and heavy REE (HREE) in comparison with typical hydrogenetic crusts. The variations in REE content are related to variations of the main mineral 
A

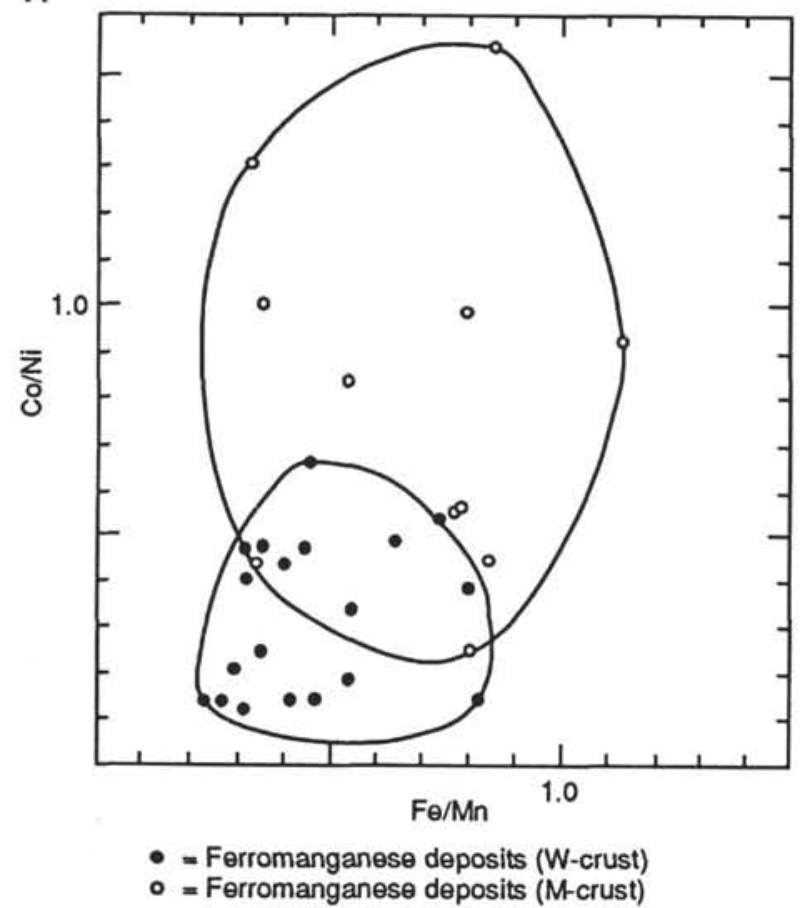

B

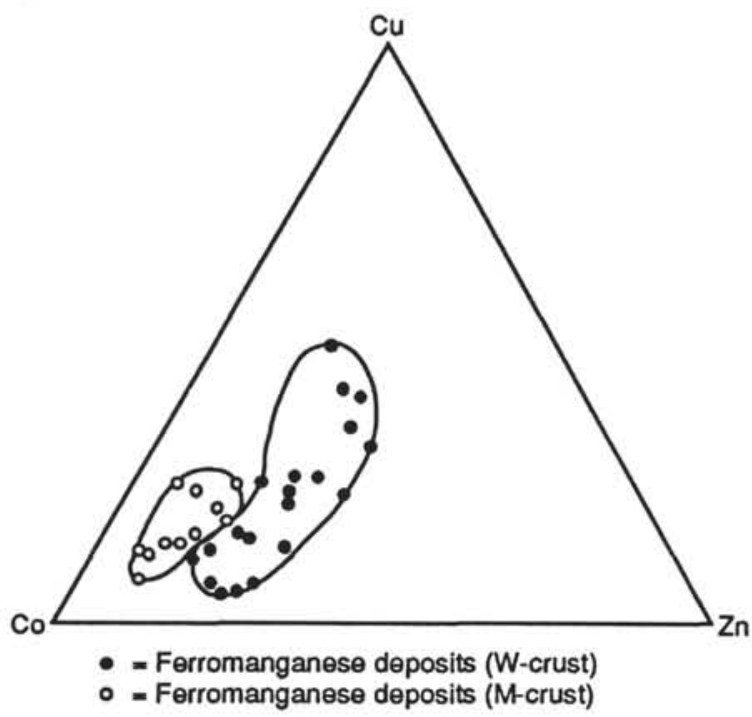

Figure 5. A. Relationship between Fe/Mn and $\mathrm{Co} / \mathrm{Ni}$ ratios in Leg 144 crust and nodules. B. Triangular diagram of Cu-Co-Zn for Leg 144 crusts and nodules.

Table 6. Correlation matrix of minor and trace elements in the southern (W-crusts) and northern (M-crusts) guyot groups, Leg 144.

\begin{tabular}{|c|c|c|c|c|c|c|c|c|c|c|c|c|c|c|}
\hline & & \multicolumn{13}{|c|}{ W-crusts } \\
\hline & & Mn & $\mathrm{Co}$ & $\mathrm{Ni}$ & $\mathrm{Cu}$ & $\mathrm{Zn}$ & $\mathrm{Pb}$ & $\mathrm{Si}$ & $\mathrm{Al}$ & $\mathrm{Ti}$ & V & $\mathrm{P}$ & $\mathrm{CaCO}_{3}$ & $\mathrm{C}_{\text {org }}$ \\
\hline $\mathrm{Fe}$ & & 0.64 & 0.54 & -0.32 & -0.23 & 0.09 & 0.88 & 0.57 & 0.04 & 0.93 & 0.76 & -0.70 & -0.40 & -0.38 \\
\hline $\mathrm{Mn}$ & 0.63 & & 0.76 & 0.22 & 0.67 & 0.62 & 0.63 & 0.22 & 0.16 & 0.80 & 0.93 & -0.81 & -0.70 & -0.35 \\
\hline Co & 0.93 & 0.80 & & 0.12 & -0.03 & 0.42 & 0.53 & 0.10 & 0.06 & 0.69 & 0.81 & -0.73 & -0.60 & -0.22 \\
\hline $\mathrm{Ni}$ & 0.66 & 0.83 & 0.68 & & 0.88 & 0.82 & -0.47 & -0.38 & 0.53 & -0.22 & -0.07 & 0.18 & -0.30 & 0.31 \\
\hline $\mathrm{Cu}$ & 0.69 & 0.90 & 0.80 & 0.86 & & 0.59 & -0.47 & -0.06 & 0.78 & -0.20 & -0.13 & 0.21 & -0.16 & 0.17 \\
\hline $\mathrm{Zn}$ & 0.79 & 0.79 & 0.78 & 0.91 & 0.91 & & 0.40 & -0.28 & 0.39 & 0.20 & 0.36 & -0.19 & -0.61 & 0.13 \\
\hline $\mathrm{Pb}$ & 0.96 & 0.77 & 0.96 & 0.74 & 0.82 & 0.86 & & 0.41 & -0.14 & 0.84 & 0.76 & -0.70 & -0.44 & -0.51 \\
\hline $\mathrm{Si}$ & 0.86 & 0.38 & 0.75 & 0.54 & 0.49 & 0.64 & 0.75 & & 0.43 & 0.58 & 0.39 & -0.56 & 0.13 & -0.54 \\
\hline $\mathrm{Al}$ & 0.93 & 0.73 & 0.96 & 0.72 & 0.77 & 0.80 & 0.94 & 0.87 & & 0.08 & 0.06 & -0.09 & -0.13 & -0.22 \\
\hline $\mathrm{Ti}$ & 0.96 & 0.76 & 0.95 & 0.72 & 0.84 & 0.87 & 0.99 & 0.72 & 0.90 & & 0.89 & -0.84 & -0.48 & -0.42 \\
\hline V & 0.69 & 0.93 & 0.78 & 0.85 & 0.90 & 0.85 & 0.83 & 0.41 & 0.72 & 0.83 & & -0.88 & -0.59 & -0.50 \\
\hline $\mathrm{P}$ & -0.83 & -0.95 & -0.92 & $\begin{array}{r}0.87 \\
-0.87\end{array}$ & -0.92 & -0.88 & -0.92 & -0.60 & -0.87 & -0.91 & -0.94 & & 0.27 & 0.60 \\
\hline $\mathrm{CaCO}_{3}$ & -0.73 & -0.91 & -0.79 & -0.87 & -0.89 & -0.85 & -0.83 & -0.40 & -0.71 & -0.84 & -0.91 & 0.94 & & 0.03 \\
\hline \multirow[t]{3}{*}{$\mathrm{C}_{\text {org }}$} & -0.46 & -0.91 & -0.60 & -0.85 & -0.84 & -0.74 & -0.57 & -0.26 & -0.54 & -0.58 & -0.81 & 0.83 & 0.86 & \\
\hline & $\mathrm{Fe}$ & $\mathrm{Mn}$ & $\mathrm{Co}$ & $\mathrm{Ni}$ & $\mathrm{Cu}$ & $\mathrm{Zn}$ & $\mathrm{Pb}$ & Si & $\mathrm{Al}$ & $\mathrm{Ti}$ & $\mathrm{V}$ & $\mathrm{P}$ & $\mathrm{CaCO}_{3}$ & \\
\hline & & & & & & & M-crus & & & & & & & \\
\hline
\end{tabular}

phases in the crusts and nodules (Fe and Mn oxyhydroxides) that incorporate these elements (Table 8). The REE pattern of the calcium phosphate phase is similar to that of dissolved REE in oceanic waters (Elderfield and Pagett, 1986; Baturin et al., 1986). Actually, the host mineral phase in two samples of W-crust (144-874B-1R-1, 0-6 cm, and $144-876 \mathrm{~A}-1 \mathrm{R}-1,35-36 \mathrm{~cm}$ ) is mainly phosphatic with minor Fe-Mn oxyhydroxides. The REE pattern of these samples is similar to the REE composition of deep-ocean waters, despite of large difference in elements concentration.

The REE concentrations in M-crusts (144-878A-1R-1, 32-35 cm; 144-878A-47R-1, 0-5 cm (caved); 144-878B-1R-1, 5-7 cm; and 144$878 \mathrm{C}-1 \mathrm{R}-1,0-5 \mathrm{~cm}$; Fig. 7C) correspond to Fe-Mn oxyhydroxides of similar composition from other seamount Fe-Mn crusts in the Pacific Ocean (Dubinin and Baturin, 1994). Comparison of the REE composition of the ODP Leg 144 crusts and nodules with pelagic crusts from the Line Islands seamounts (Aplin, 1984) and from the deep-ocean waters of Mariana Trench (2500 m; Klinkhammer et al., 1983) shows that some of the Leg 144 ferromanganese crusts such as from Wodejebato Guyot (144-874B-1R-1, 0-6 cm (N2); 144-876A-1R-1, 35-36 $\mathrm{cm}$ ) are enriched in $\mathrm{Ce}$, with the $\mathrm{Ce} / \mathrm{Nd}$ ratio similar to, or higher than, the mean value of the Line Islands seamount crusts (Fig. 8). Calcium phosphate seems to have principal influence on the fixation of HREE (Table 8). The La/Nd ratio (Fig. 8) of the Fe-Mn crusts is similar to that for oceanic waters which indicates an extrinsic relationship between $\mathrm{La}$ and phosphate phase. Lanthanum as the sole element of light REE (LREE) has a behavior similar to HREE (Table 9). The Er/Nd ratio in Leg 144 crusts and nodules (Fig. 8) is higher than in the Line Islands seamount crusts and lower than in oceanic waters. The $\mathrm{Er} / \mathrm{La}$ ratio in Leg 144 crusts (Fig. 8) and the Line Islands seamount crusts is similar. Similar $\mathrm{Yb} / \mathrm{Nd}$ ratios for Leg 144 crusts have been obtained from crusts of Hawaiian seamounts by De Carlo (1991).

Correlation matrices of REE (Tables 8 and 9) show that the relationship between the concentration of REE and principal crust elements $(\mathrm{Fe}+\mathrm{Mn})$ is weakened by an increase in the atomic number of 
A
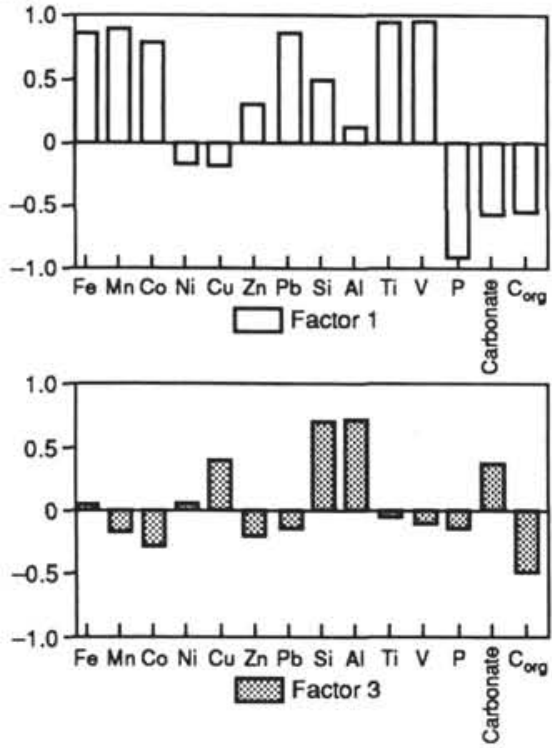

B
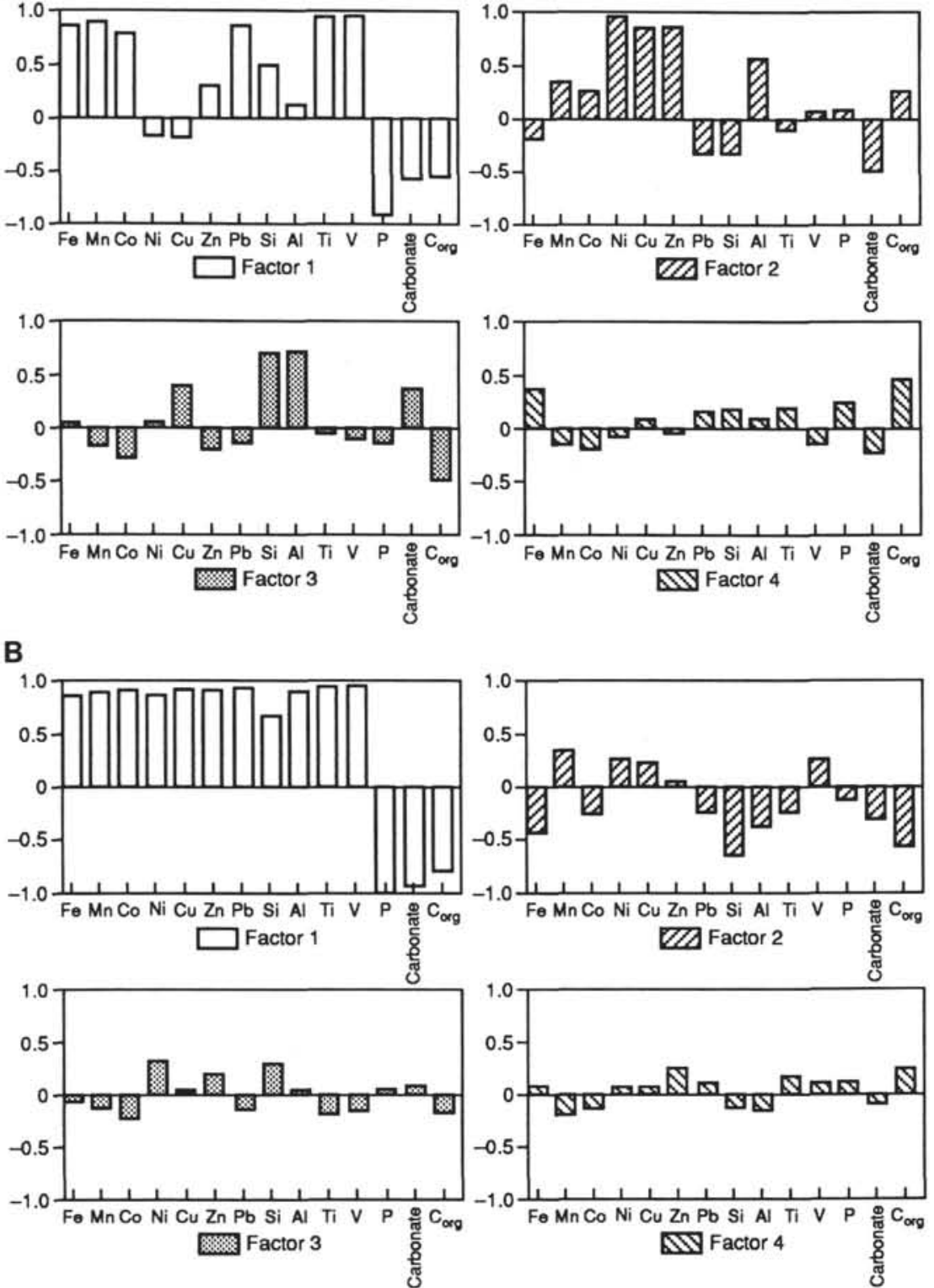

Figure 6. A. Normalized loading factors for first four factors of the W-crusts. B. Normalized loading factors for first four factors of the M-crusts. the REE. The distinguishing feature of REE in association with the P-phase in crusts is a distinct positive anomaly of $\mathrm{Gd}\left[\mathrm{Gd}^{*}=2(\mathrm{Gd} / \mathrm{Gd}\right.$ shale $) /(\mathrm{Eu} / \mathrm{Eu}$ shale $+\mathrm{Tb} / \mathrm{Tb}$ shale $)]$. This anomaly is related to the properties of the element $\mathrm{Tb}$ (heightened stability) of Gd-complexes when compared with Eu and Tb (De Baar et al., 1985a, 1985b). This anomaly was noted also in Hawaiian seamount crusts by De Carlo (1991). The origin of this anomaly could be the result of fixation of dissolved REE from oceanic waters by phosphate. Such a hypothesis is supported by the correlation matrix, which shows the relationship between the Gd* anomaly and P content in Leg 144 crusts and nodules (Fig. 9). The Gd*/P lines of the $\mathrm{W}$ - and M-crusts have very different slopes as a result of the different levels of $\mathrm{P}$ content.

The REE composition of Leg 144 crusts and nodules is influenced by the presence of main host phases (Fe-Mn oxyhydroxide and/or phosphate). A model of the REE composition of a mixture of two crusts of diametrically opposite composition is shown in Figure 10. The M-crust is represented by a purest ferromanganese phase (144$878 \mathrm{~A}-1 \mathrm{R}-1,32-35 \mathrm{~cm})$ and the W-crust by a sample of pure phosphate phase (144-876A-1R-1, 35-36 cm).

\section{DISCUSSION \\ AND PALEOCEANOGRAPHIC IMPLICATIONS}

The mineralogical and chemical composition of Fe-Mn crusts recovered from the northwestern Pacific guyots during Leg 144 confirms their hydrogenetic origin. All chemical components of these deposits, except for detrital (terrigenous) matter, are derived by precipitation from seawater. Fe-Mn crusts cover substrates of different compositions, including basalts, volcaniclastics, conglomerates, shallow-water and pelagic limestones. However, no correlation between the chemistry of the $\mathrm{Fe}-\mathrm{Mn}$ crusts and the underlying substrate could be established.

The influence of carbonate and silica plankton dissolution on the metal concentration in seawater and on ferromanganese deposits has been discussed by several authors (e.g., Holbach and Puteanus, 1984). From these studies the most important implication is that increases in fertility and deep water activity, which are controlled in the northwestern Pacific crusts by Intermediate Antarctic Water, would result in an increase of metal supply and thus influence the concentration of 


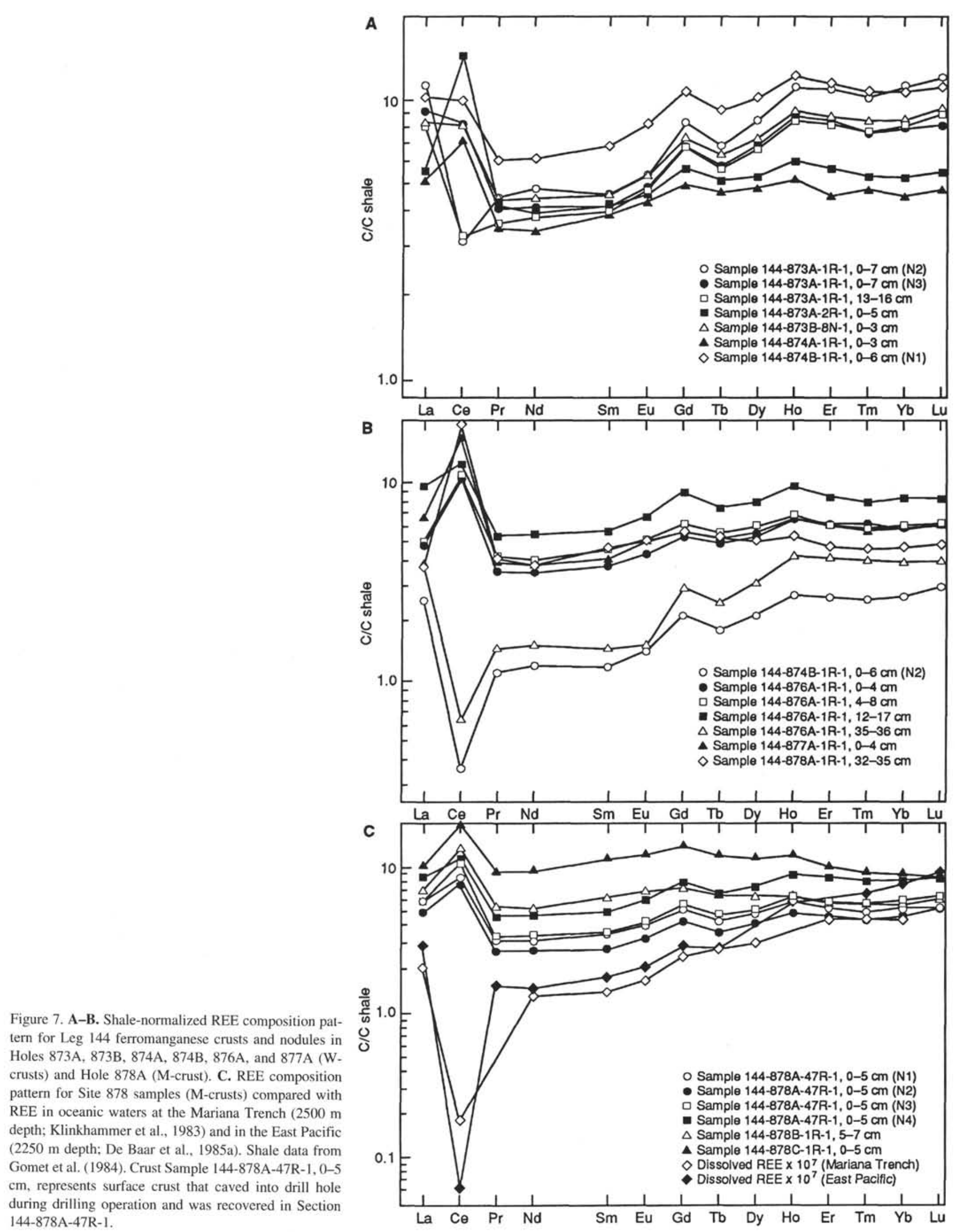


Table 7. Concentrations of REE in Fe-Mn crusts and nodules, Leg 144.

\begin{tabular}{|c|c|c|c|c|c|c|c|c|c|c|c|c|c|c|c|}
\hline $\begin{array}{l}\text { Core, section, } \\
\text { interval }(\mathrm{cm})\end{array}$ & $\begin{array}{c}\text { Sample } \\
\text { no. }\end{array}$ & $\begin{array}{c}\mathrm{La} \\
(\mathrm{ppm})\end{array}$ & $\begin{array}{c}\mathrm{Ce} \\
(\mathrm{ppm})\end{array}$ & $\begin{array}{c}\mathrm{Pr} \\
(\mathrm{ppm})\end{array}$ & $\begin{array}{l}\mathrm{Nd} \\
(\mathrm{ppm})\end{array}$ & $\begin{array}{c}\mathrm{Sm} \\
(\mathrm{ppm})\end{array}$ & $\begin{array}{c}\text { Eu } \\
(\mathrm{ppm})\end{array}$ & $\begin{array}{c}\text { Gd } \\
\text { (ppm) }\end{array}$ & $\begin{array}{c}\mathrm{Tb} \\
(\mathrm{ppm})\end{array}$ & $\begin{array}{c}\text { Dy } \\
(\mathrm{ppm})\end{array}$ & $\begin{array}{l}\text { Ho } \\
(\mathrm{ppm})\end{array}$ & $\begin{array}{c}\text { Er } \\
(\mathrm{ppm})\end{array}$ & $\underset{(\mathrm{ppm})}{\mathrm{Tm}}$ & $\begin{array}{c}\mathrm{Yb} \\
(\mathrm{ppm})\end{array}$ & $\begin{array}{c}\mathrm{Lu} \\
(\mathrm{ppm})\end{array}$ \\
\hline $\begin{array}{l}144-873 \mathrm{~A}- \\
\text { IR-1,0-7 } \\
\text { IR-1, 0-7 } \\
\text { IR-1, 13-16 } \\
\text { 2R-1, 0-5 }\end{array}$ & $\begin{array}{l}2 \\
3\end{array}$ & $\begin{array}{l}356 \\
292 \\
259 \\
179\end{array}$ & $\begin{array}{r}222 \\
610 \\
235 \\
1070\end{array}$ & $\begin{array}{l}34.9 \\
32.0 \\
28.4 \\
32.8\end{array}$ & $\begin{array}{l}158 \\
137 \\
126 \\
128\end{array}$ & $\begin{array}{l}26.2 \\
23.6 \\
22.8 \\
24.2\end{array}$ & $\begin{array}{l}6.66 \\
6.01 \\
5.85 \\
5.72\end{array}$ & $\begin{array}{l}44.0 \\
36.3 \\
36.1 \\
30.1\end{array}$ & $\begin{array}{l}5.85 \\
4.95 \\
4.85 \\
4.40\end{array}$ & $\begin{array}{l}44.6 \\
36.2 \\
35.6 \\
27.8\end{array}$ & $\begin{array}{r}11.74 \\
9.32 \\
8.97 \\
6.42\end{array}$ & $\begin{array}{l}37.8 \\
29.1 \\
28.5 \\
19.5\end{array}$ & $\begin{array}{l}5.24 \\
3.92 \\
3.85 \\
2.69\end{array}$ & $\begin{array}{l}35.2 \\
25.1 \\
25.5 \\
16.6\end{array}$ & $\begin{array}{l}5.88 \\
3.98 \\
4.38 \\
2.70\end{array}$ \\
\hline $\begin{array}{r}144-873 \mathrm{~B}- \\
8 \mathrm{~N}-1,0-3\end{array}$ & & 269 & 599 & 34.3 & 147 & 26.0 & 6.70 & 38.6 & 5.46 & 38.4 & 9.70 & 30.1 & 4.28 & 26.9 & 4.56 \\
\hline $\begin{array}{l}144-874 \mathrm{~A}- \\
\text { IR-1,0-3 }\end{array}$ & & 163 & 532 & 27.4 & 113 & 22.4 & 5.36 & 26.0 & 4.02 & 25.1 & 5.48 & 15.6 & 2.40 & 14.2 & 2.33 \\
\hline $\begin{array}{r}144-874 \mathrm{~B}- \\
1 \mathrm{R}-1,0-6 \\
1 \mathrm{R}-1,0-6\end{array}$ & $\begin{array}{l}1 \\
2\end{array}$ & $\begin{array}{r}330 \\
80.9\end{array}$ & $\begin{array}{l}730 \\
26.2\end{array}$ & $\begin{array}{l}47.9 \\
8.81\end{array}$ & $\begin{array}{l}205 \\
39.4\end{array}$ & $\begin{array}{l}39.5 \\
6.73\end{array}$ & $\begin{array}{l}10.3 \\
1.76\end{array}$ & $\begin{array}{l}56.8 \\
11.0\end{array}$ & $\begin{array}{l}7.79 \\
1.52\end{array}$ & $\begin{array}{l}54.2 \\
10.9\end{array}$ & $\begin{array}{c}12.9 \\
2.82\end{array}$ & $\begin{array}{l}39.8 \\
8.96\end{array}$ & $\begin{array}{l}5.38 \\
1.27\end{array}$ & $\begin{array}{r}34.0 \\
8.2\end{array}$ & $\begin{array}{l}5.46 \\
1.43\end{array}$ \\
\hline $\begin{array}{l}144-876 \mathrm{~A}- \\
\text { IR-1, 0-4 } \\
\text { IR-1, 4-8 } \\
\text { IR-1, 12-17 } \\
\text { IR-1, 35-36 }\end{array}$ & & $\begin{array}{l}154 \\
162 \\
312 \\
124\end{array}$ & $\begin{array}{l}772 \\
797 \\
911 \\
47.4\end{array}$ & $\begin{array}{l}28.1 \\
32.7 \\
42.5 \\
11.5\end{array}$ & $\begin{array}{c}116 \\
134 \\
181 \\
50.0\end{array}$ & $\begin{array}{c}21.4 \\
26.0 \\
32.5 \\
8.23\end{array}$ & $\begin{array}{l}5.40 \\
6.34 \\
8.22 \\
1.84\end{array}$ & $\begin{array}{l}27.8 \\
31.7 \\
46.8 \\
15.2\end{array}$ & $\begin{array}{l}4.18 \\
4.63 \\
6.24 \\
2.07\end{array}$ & $\begin{array}{l}27.8 \\
30.9 \\
41.6 \\
16.2\end{array}$ & $\begin{array}{l}6.70 \\
7.04 \\
9.95 \\
4.43\end{array}$ & $\begin{array}{l}20.7 \\
20.6 \\
28.6 \\
14.1\end{array}$ & $\begin{array}{l}2.83 \\
2.92 \\
3.99 \\
2.02\end{array}$ & $\begin{array}{l}18.3 \\
18.8 \\
25.9 \\
12.3\end{array}$ & $\begin{array}{l}2.95 \\
3.01 \\
4.01 \\
1.95\end{array}$ \\
\hline $\begin{array}{l}144-877 \mathrm{~A}- \\
\text { IR- } 1,0-4\end{array}$ & & 213 & 1236 & 31.1 & 127 & 23,4 & 6.30 & 29.0 & 4.48 & 29.2 & 6.83 & 21.1 & 3.07 & 18.3 & 2.90 \\
\hline $\begin{array}{c}144-878 \mathrm{~A}- \\
1 \mathrm{R}-1,32-35 \\
47 \mathrm{R}-1,0-5 \\
47 \mathrm{R}-1,0-5 \\
47 \mathrm{R}-1,0-5 \\
47 \mathrm{R}-1,0-5\end{array}$ & $\begin{array}{l}1 \\
2 \\
3 \\
4\end{array}$ & $\begin{array}{l}120 \\
188 \\
156 \\
188 \\
277\end{array}$ & $\begin{array}{r}1430 \\
625 \\
571 \\
793 \\
851\end{array}$ & $\begin{array}{l}32.1 \\
24.8 \\
20.7 \\
25.7 \\
36.7\end{array}$ & $\begin{array}{l}125 \\
102 \\
87.4 \\
111 \\
156\end{array}$ & $\begin{array}{l}26.8 \\
19.7 \\
15.5 \\
20.1 \\
28.5\end{array}$ & $\begin{array}{l}6.08 \\
4.95 \\
4.01 \\
5.19 \\
7.75\end{array}$ & $\begin{array}{l}29.5 \\
27.9 \\
22.6 \\
29.1 \\
41.8\end{array}$ & $\begin{array}{l}4.36 \\
3.69 \\
3.11 \\
4.05 \\
5.77\end{array}$ & $\begin{array}{l}26.2 \\
25.7 \\
22.1 \\
27.2 \\
39.2\end{array}$ & $\begin{array}{l}5.53 \\
6.15 \\
5.21 \\
6.76 \\
9.61\end{array}$ & $\begin{array}{l}16.1 \\
18.5 \\
16.2 \\
20.2 \\
30.2\end{array}$ & $\begin{array}{l}2.31 \\
2.47 \\
2.23 \\
2.87 \\
4.09\end{array}$ & $\begin{array}{l}14.7 \\
16.7 \\
14.4 \\
18.7 \\
25.9\end{array}$ & $\begin{array}{l}2.34 \\
2.56 \\
2.53 \\
3.12 \\
4.29\end{array}$ \\
\hline $\begin{array}{l}\text { 144-878B- } \\
\text { IR-I, 5-7 }\end{array}$ & & 225 & 1004 & 42.3 & 171 & 36.3 & 8.36 & 39.1 & 5.67 & 33.7 & 6.88 & 19.6 & 2.83 & 17.2 & 2.99 \\
\hline $\begin{array}{l}\text { 144-878C- } \\
\text { IR-1, 0-5 } \\
\text { Shale (NASC) }\end{array}$ & & $\begin{array}{r}330 \\
32\end{array}$ & $\begin{array}{r}1458 \\
73\end{array}$ & $\begin{array}{r}72.7 \\
7.9\end{array}$ & $\begin{array}{r}309 \\
33\end{array}$ & $\begin{array}{r}65.5 \\
5.7\end{array}$ & $\begin{array}{c}15.3 \\
1.24\end{array}$ & $\begin{array}{r}72.5 \\
5.2\end{array}$ & $\begin{array}{c}10.3 \\
0.85\end{array}$ & $\begin{array}{r}60.6 \\
5.2\end{array}$ & $\begin{array}{r}12.68 \\
1.04\end{array}$ & $\begin{array}{r}34.7 \\
3.4\end{array}$ & $\begin{array}{l}4.64 \\
0.5\end{array}$ & $\begin{array}{r}27.9 \\
3.1\end{array}$ & $\begin{array}{l}4.14 \\
0.48\end{array}$ \\
\hline
\end{tabular}

Table 8. Correlation matrix of REE and main host elements of Fe-Mn crusts, Leg 144.

\begin{tabular}{|c|c|c|c|c|c|c|c|c|c|c|c|c|c|c|c|c|c|c|c|c|}
\hline $\mathrm{La}$ & $\mathrm{Ce}$ & $\operatorname{Pr}$ & Nd & $\mathrm{Sm}$ & Eu & Gd & $\mathrm{Tb}$ & Dy & Ho & Er & $\mathrm{Tm}$ & $\mathrm{Yb}$ & Lu & $\mathrm{Fe}$ & $\mathrm{Mn}$ & $\mathrm{Fe}+\mathrm{Mn}$ & P & $\mathrm{Mn} / \mathrm{Fe}$ & $\mathrm{Fe} / \mathrm{P}$ & \\
\hline 1.000 & $\begin{array}{l}0.154 \\
1.000\end{array}$ & $\begin{array}{l}0.727 \\
0.664 \\
1.000\end{array}$ & $\begin{array}{l}0.771 \\
0.607 \\
0.996 \\
1.000\end{array}$ & $\begin{array}{l}0.667 \\
0.659 \\
0.992 \\
0.986 \\
1.000\end{array}$ & $\begin{array}{l}0.727 \\
0.639 \\
0.994 \\
0.993 \\
0.992 \\
1.000\end{array}$ & $\begin{array}{l}0.860 \\
0.482 \\
0.961 \\
0.978 \\
0.942 \\
0.966 \\
1.000\end{array}$ & $\begin{array}{l}0.819 \\
0.547 \\
0.981 \\
0.992 \\
0.966 \\
0.985 \\
0.993 \\
1.000\end{array}$ & $\begin{array}{l}0.911 \\
0.399 \\
0.916 \\
0.941 \\
0.884 \\
0.922 \\
0.985 \\
0.973 \\
1.000\end{array}$ & $\begin{array}{l}0.958 \\
0.239 \\
0.803 \\
0.843 \\
0.754 \\
0.810 \\
0.925 \\
0.896 \\
0.973 \\
1.000\end{array}$ & $\begin{array}{l}0.956 \\
0.144 \\
0.714 \\
0.759 \\
0.656 \\
0.722 \\
0.862 \\
0.825 \\
0.931 \\
0.989 \\
1.000\end{array}$ & $\begin{array}{l}0.958 \\
0.147 \\
0.711 \\
0.755 \\
0.651 \\
0.716 \\
0.855 \\
0.821 \\
0.927 \\
0.985 \\
0.997 \\
1.000\end{array}$ & $\begin{array}{l}0.950 \\
0.088 \\
0.656 \\
0.704 \\
0.592 \\
0.661 \\
0.817 \\
0.774 \\
0.896 \\
0.971 \\
0.992 \\
0.994 \\
1.000\end{array}$ & $\begin{array}{l}0.930 \\
0.021 \\
0.592 \\
0.642 \\
0.526 \\
0.598 \\
0.763 \\
0.718 \\
0.853 \\
0.941 \\
0.975 \\
0.979 \\
0.991 \\
1.000\end{array}$ & $\begin{array}{l}0.208 \\
0.769 \\
0.684 \\
0.634 \\
0.694 \\
0.654 \\
0.506 \\
0.566 \\
0.416 \\
0.241 \\
0.136 \\
0.158 \\
0.104 \\
0.078 \\
1.000\end{array}$ & $\begin{array}{l}0.221 \\
0.726 \\
0.594 \\
0.545 \\
0.577 \\
0.552 \\
0.453 \\
0.528 \\
0.442 \\
0.335 \\
0.284 \\
0.311 \\
0.255 \\
0.221 \\
0.647 \\
1.000\end{array}$ & $\begin{array}{l}0.236 \\
0.805 \\
0.678 \\
0.626 \\
0.669 \\
0.637 \\
0.512 \\
0.589 \\
0.472 \\
0.331 \\
0.257 \\
0.284 \\
0.223 \\
0.190 \\
0.829 \\
0.962 \\
1.000\end{array}$ & $\begin{array}{r}-0.071 \\
-0.661 \\
-0.553 \\
-0.500 \\
-0.568 \\
-0.518 \\
-0.378 \\
-0.457 \\
-0.328 \\
-0.180 \\
-0.109 \\
-0.134 \\
-0.070 \\
-0.041 \\
-0.732 \\
-0.906 \\
-0.924 \\
1.000\end{array}$ & $\begin{array}{r}0.129 \\
-0.159 \\
-0.057 \\
-0.047 \\
-0.089 \\
-0.087 \\
0.000 \\
0.007 \\
0.094 \\
0.181 \\
0.242 \\
0.253 \\
0.242 \\
0.230 \\
-0.364 \\
0.347 \\
0.124 \\
-0.170 \\
1.000\end{array}$ & $\begin{array}{r}-0.169 \\
0.591 \\
0.271 \\
0.215 \\
0.312 \\
0.243 \\
0.120 \\
0.167 \\
0.039 \\
-0.100 \\
-0.158 \\
-0.147 \\
-0.172 \\
-0.182 \\
0.631 \\
0.634 \\
0.689 \\
-0.725 \\
-0.013 \\
1.000\end{array}$ & $\begin{array}{l}\mathrm{La} \\
\mathrm{Ce} \\
\mathrm{Pr} \\
\mathrm{Nd} \\
\mathrm{Sm} \\
\mathrm{Eu} \\
\mathrm{Gd} \\
\mathrm{Tb} \\
\mathrm{Dy} \\
\mathrm{Ho} \\
\mathrm{Er} \\
\mathrm{Tm} \\
\mathrm{Yb} \\
\mathrm{Lu} \\
\mathrm{Fe} \\
\mathrm{Mn} \\
\mathrm{Fe}+\mathrm{Mn} \\
\mathrm{P} \\
\mathrm{Mn} / \mathrm{Fe} \\
\mathrm{Fe} / \mathrm{P}\end{array}$ \\
\hline
\end{tabular}

biogenic elements in the hydrogenetic ferromanganese precipitates that are found on seamounts from this region.

The precipitation of Fe-Mn oxyhydroxides occurred during an extensive period of nondeposition of carbonates. It postdates the drowning of the shallow-water carbonate platforms and "atolls" (Fig. 2). At the southern group of guyots, the Fe-Mn crusts were buried under a pelagic carbonate cap during the late Cenozoic. In contrast, the pelagic carbonate cap is missing at the northern group of guyots, since these guyots migrated across the equatorial Pacific during the Late Cretaceous, which according to L.F. Jansa et al. (unpubl. data) was a lowproductivity region at that time as supported by a lower precipitation rate of the M-crusts. The Fe-Mn crusts at the southern group of guyots were deposited within a 30-m.y. time window, and at the northern group of guyots within a 60-m.y. time window.
The study of major and trace element geochemistry of central Pacific seamount deposits has shown that many elements exhibit a similar depth-related dichotomy. According to Aplin (1984), crusts from $1-2 \mathrm{~km}$ depth should have higher $\mathrm{Mn} / \mathrm{Fe}$ ratios and contain greater concentrations of $\mathrm{Mn}$ and $\mathrm{Mn}$-associated elements such as $\mathrm{Co}$ and $\mathrm{Ni}$ than crusts from deeper than $2 \mathrm{~km}$. Analyses of crusts from the northwestern Pacific guyots located between 1000 and $1500 \mathrm{~m}$ water depth show the presence of both types of crusts (enriched and depleted in Mn).

One of the limiting factors for the formation of Fe-Mn oxyhydroxides deposits is the effect of the surface water bioproductivity on the position of the oxic and suboxic environment boundary and the base of the oxygen-minimum zone. The importance of this boundary is that Mn does not accumulate in a low oxygen environment. The miner- 

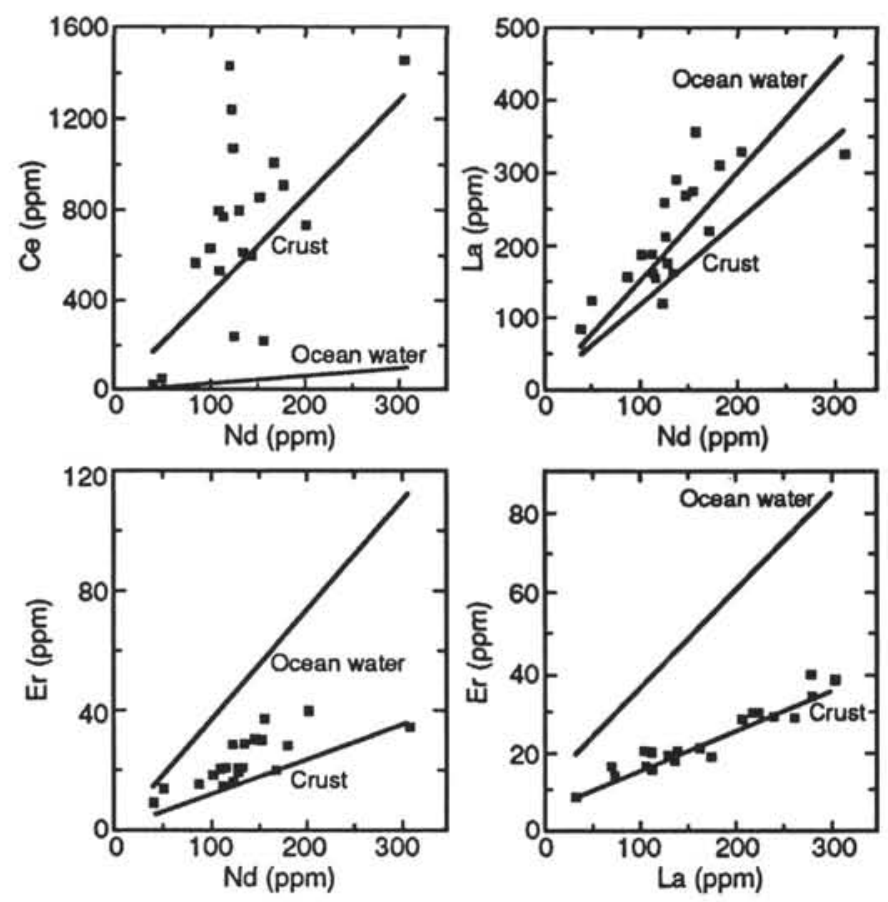

Figure 8. Relationship of Ce vs, Nd, La vs. Nd, Er vs. Nd, and Er vs. La in Leg 144 ferromanganese crusts shown by square symbols and in crusts on Line Islands Archipelago (Aplin, 1994) and in deep-ocean water (data given in Fig. 7C).

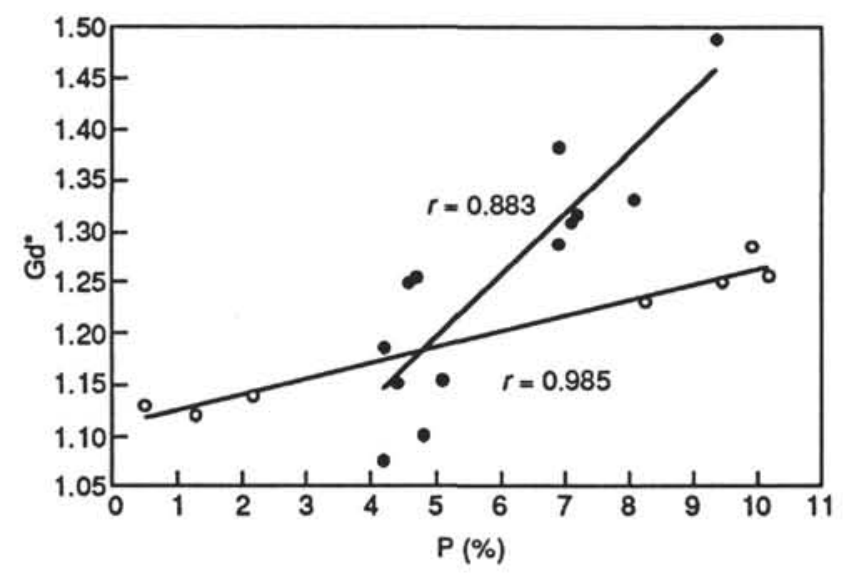

- = Ferromanganese deposits (W-crust)

$\circ=$ Ferromanganese deposits (M-crust)

Figure 9. Linear regression lines of relationship between $\mathrm{Gd}$ anomaly $\left[\mathrm{Gd}^{*}=\right.$ $2(\mathrm{Gd} / \mathrm{Gd}$ shale $) /(\mathrm{Eu} / \mathrm{Eu}$ shale $+\mathrm{Tb} / \mathrm{Tb}$ shale $)]$ and $\mathrm{P}$ content in $\mathrm{M}$ - and W-crusts from northwestern Pacific guyots, Leg 144.

alogical and chemical composition of crusts at the southern group of guyots show a similarity with ferromanganese nodules which are widely distributed at the periphery of the equatorial belt in the eastern part of the Pacific (Bogdanov et al., 1990). The chemical composition of M-crusts and nodules, as the sole representative of the northern group of guyots, indicates that ferromanganese precipitation occurred predominantly within the low-productivity zone of the ocean. However, the presence of mixed mineral phases in the older parts of the $\mathrm{M}$-crusts confirms that they were formed under variable environmental conditions, indicating fluctuation in water column composition.

The presence of mixed mineral phases in the Fe-Mn crusts may be an indication of diagenetic changes, which led to changes in the
Table 9. Correlation matrix of main elements and some of the REE ratios of the host phases of Fe-Mn crusts and nodules, Leg 144.

\begin{tabular}{lrrrr}
\hline & $\mathrm{Ce} / \mathrm{Nd}$ & $\mathrm{Er} / \mathrm{Nd}$ & $\mathrm{La} / \mathrm{Nd}$ & \multicolumn{1}{c}{$\mathrm{Gd}^{*}$} \\
\hline $\mathrm{Fe}$ & 0.500 & -0.883 & -0.798 & -0.743 \\
$\mathrm{Mn}$ & 0.553 & -0.620 & -0.699 & -0.690 \\
$\mathrm{Fe}+\mathrm{Mn}$ & 0.583 & -0.768 & -0.796 & -0.770 \\
$\mathrm{P}$ & -0.420 & 0.674 & 0.743 & 0.705 \\
$\mathrm{Fe} / \mathrm{P}$ & 0.536 & -0.571 & -0.623 & -0.468 \\
\hline
\end{tabular}

Note: $\mathrm{Gd}^{*}=2(\mathrm{Gd} / \mathrm{Gd}$ shale $) /(\mathrm{Eu} / \mathrm{Eu}$ shale $+\mathrm{Tb} / \mathrm{Tb}$ shale $)$

mineralogy, but not in the chemical composition of the crusts. Specifically the REE would not change, because they are less subject to factionation in the sedimentary cycle than most of other elements (Koepenkastrop and De Carlo, 1992). The sequence of events that led to the formation of mixed mineral phases could be as follows: (1) $\mathrm{Fe}$-vernadite and $\mathrm{Mn}$-feroxyhyte precipitation in a low-productivity zone; (2) development of a local microenvironment because of increased organic matter accumulation, either as a result of increased bioproductivity or an expanded oxygen-minimum zone, causing Mn in vernadite to be solubilized and reduced to the divalent (soluble) state. Asbolane-buserite and birnessite could form under these suboxic conditions. It is very probable that the latter conditions could develop in the biologically productive zone of the Equatorial Pacific. Considering that the precipitation of Leg $144 \mathrm{Fe}-\mathrm{Mn}$ crusts occurred at a water depth of $400-800 \mathrm{~m}$, the mineralogical variability of the crusts reflects chemical variability in metal concentrations in the surface and intermediate water masses of equatorial Pacific. This is supported by microsampling of W-crust at Site 876 (Table 2) documenting increased bioelement concentrations within the middle and upper third of the crust. The biostratigraphic study of the crust (Premoli Silva, Haggerty, Rack, et al., 1993) documents an early Eocene to late middle Eocene age of the crust, thus the element enrichment would have occurred near the early-middle Eocene boundary.

The presence of "low-productivity" mineral phases (Fe-vernadite and Mn-feroxyhyte) in W-crusts at Site 874 , located at the inner perimeter ridge of Wodejebato Guyot, is surprising, and documents a strong influence of a local low-productivity depositional environment on Fe-Mn crust precipitation.

The mineralogical composition of M-crusts and nodules (some of which were found encased in Neogene and Pleistocene sediments characteristic of a low-productivity zone) must have been originally composed of Fe-vernadite and Mn-ferroxyhyte. The presence of asbolane-buserite, birnessite, and apparently todorokite in samples from the lower part of the crust at Hole $878 \mathrm{~B}$ indicates that part of these deposits and the nuclei of some of the nodules composed of older clasts of the ferromanganese crusts were formed during the crossing of the equatorial "productive" zone by the seamount. The age of the crust is poorly constrained by the underlying shallow-water carbonate platform of Albian age and by attached early Pleistocene carbonate mud at the crust surface (Premoli Silva, Haggerty, Rack, et al., 1993).

However, at the nearby Hole $878 \mathrm{~A}$ the oldest ferromanganese precipitation is dated by nannofossils as being of pre-Santonian age (Premoli Silva, Haggerty, Rack, et al., 1993). The lower concentration of biogenic elements in older "Late Cretaceous" M-crusts can be interpreted as an indication of lower productivity in the equatorial region during Late Cretaceous than during the Cenozoic.

Increases in $\mathrm{Si} / \mathrm{Al}$ in $\mathrm{M}$-crust suggest an input of wind-borne terrigenous particles, which settled in much higher quantities at the top of the Takuyo-Daisan Guyot.

Our study did not confirm the Halbach and Puteanus (1984) hypothesis of a relationship between concentration of Co in crusts and substratum morphology. The Fe-Mn crusts from plateaus of northwestern Pacific guyots have concentrations of Co which are mostly lower than $0.5 \%$ and not up to $2 \%$ as predicted by the above authors. 


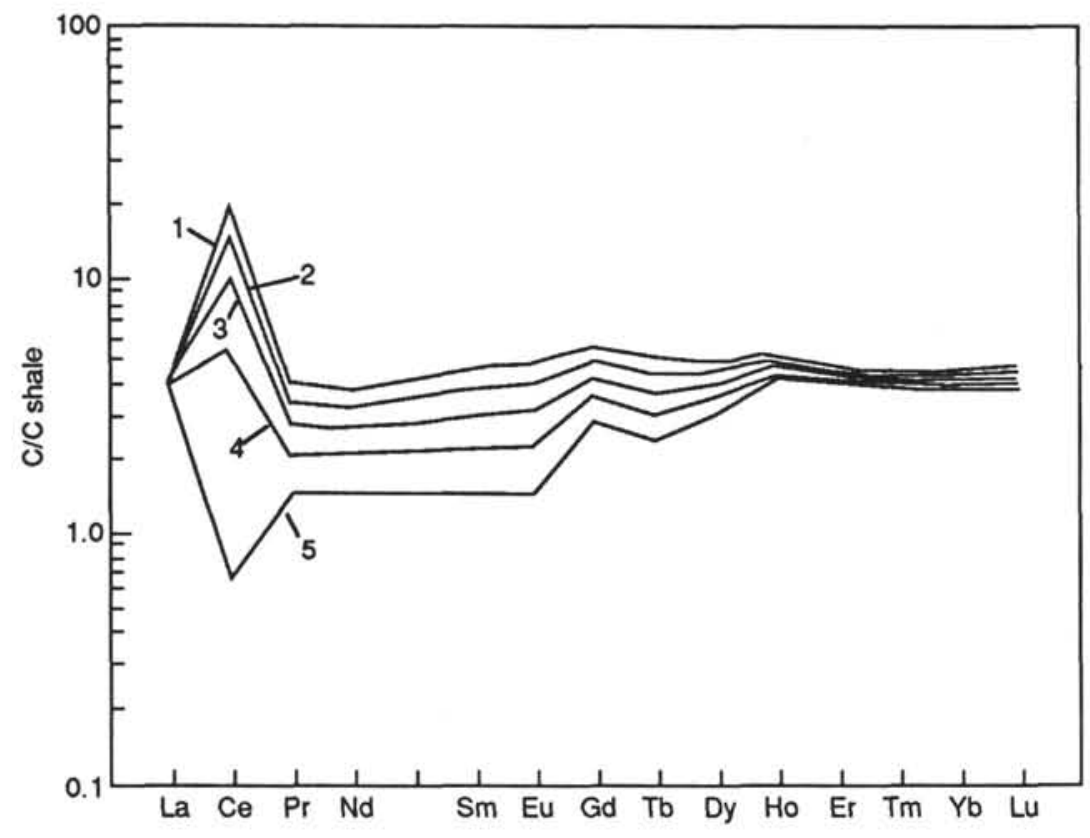

Figure 10. Model of REE composition of Fe-Mn crusts as a result of mixing the end-member types of the ferromanganese phase of the M-crust (Sample 144-878A-1R-1, 32-35 $\mathrm{cm} ; \mathrm{Fe}+\mathrm{Mn} 37.7 \%, \mathrm{P}=0.51 \%$ ) and the phosphate phase of the W-crust (Sample 144-876A-1R-1, 35-36 cm; Fe+Mn = $6.33 \%, \mathrm{P}=9.4 \%) . \mathrm{I}=100 \%$ of Sample $144-878 \mathrm{~A}-1 \mathrm{R}-1$, $32-35 \mathrm{~cm} ; 2=75 \%$ of the same sample; $3=50 \%$ of the same sample; $4=25 \%$ of the same sample; and $5=100 \%$ of Sample 144-876A-1R-1, $35-36 \mathrm{~cm}$.

\section{Depth and Paleolatitude}

The geologic and subsidence history of the guyots (Fig. 3), integrated with the lateral motion of plates (Larson et al., this volume), indicates that $\mathrm{Fe}-\mathrm{Mn}$ crust began to precipitate soon after the surfaces of carbonate platforms were submerged deeper than about $120 \mathrm{~m}$ water depth. Traces of pelagic sediment were found enclosed by Fe-Mn crusts at the MIT Guyot (Premoli Silva, Haggerty, Rack, et al., 1993), when the projected top of the guyot was at about $400 \mathrm{~m}$ water depth. The intermittent pelagic deposition, evidenced by pelagic sediment enclosed by the crusts and nodules, occurred when both the Wodejebato and MIT guyot surfaces were at $620-800 \mathrm{~m}$ water depth, notwithstanding that the guyots' surfaces reached this depth at different geologic times. This implies that the intrinsic relationship between pelagic deposition, currents, and bioproductivity are mostly independent of age. The crusts' precipitation continued until the tops of the guyots subsided to a depth of about $850-1050 \mathrm{~m}$ (Fig. 3). Calculated paleolatitudes for MIT Guyot indicate that Fe-Mn crust precipitation began when the guyot was located in the equatorial zone (ca. $1^{\circ} \mathrm{N}$; Larson et al., this volume). The guyot moved rapidly in a northwesterly direction reaching the paleolatitude of about $13^{\circ}-14^{\circ} \mathrm{N}$ during the late Paleocene to early Eocene. The paleolatitudinal position of MIT Guyot thus indicates that during the initial phases of $\mathrm{Fe}-\mathrm{Mn}$ crust deposition, the guyot was located in the equatorial zone, which during the Late Cretaceous was a region of relatively low productivity, and for most of the time the guyot remained resident in a low-productivity region. In contrast, Wodejebato Guyot at the beginning of Fe-Mn crust precipitation was located at $4^{\circ}-2^{\circ} \mathrm{S}$ paleolatitude and remained in the equatorial high-productivity zone for most of the time. The chemical composition, mineralogical assemblages of crusts, and difference in precipitation rates discussed in this paper support a low-productivity realm for the M-crusts and an increased productivity realm for the $\mathrm{W}$-crusts, thus providing independent confirmation of the paleolatitudinal position of the guyots.

\section{Currents}

The process of ferromanganese crusts precipitation requires a delicate balance between the flux of pelagic material and sediment removal, influenced partially by bottom currents, and partially by the dissolution of pelagic calcium carbonate and siliceous tests. If the depositional flux surpasses removal, then pelagic sediments will ac- cumulate. Bogdanov et al. (1990) suggested that ferromanganese crusts can form within the narrow limits of bottom currents with velocities of 0.5 to $30 \mathrm{~cm} / \mathrm{s}$. Presence of winnowed foraminifer sands at the top of some of the crusts at the guyots (with foraminifer tests sized from 0.1 to $0.26 \mathrm{~mm}$ ) suggest that Fe-Mn crust will form even if the current velocity is as low as $>0.1 \mathrm{~cm} / \mathrm{s}$. The upper limit of the current velocity is uncertain, but from the Fe-Mn oxyhydroxides coatings of reworked limestone pebbles that are up to $2 \mathrm{~cm}$ in diameter, the upper limit of currents for Fe-Mn crust deposition must be $<100 \mathrm{~cm} / \mathrm{s}$.

The lack of pelagic carbonate accumulation at the guyot surfaces during Late Cretaceous-early Tertiary time could result either from low productivity combined with high carbonate dissolution, or from an erosion by currents. The presence of pelagic carbonate incorporated into $\mathrm{Fe}-\mathrm{Mn}$ crust and nodules and infilling borings within the crust favors the second hypothesis and indicate at least periodic presence of currents with velocities $>38 \mathrm{~cm} / \mathrm{s}$.

The paleolatitudinal position of the guyots and their subsidence histories locate the individual guyot surfaces in the realm of the South and North Subsurface Countercurrents and of the Equatorial Intermediate Undercurrent (Tomscak and Godfrey, 1993) during the initial stages of Fe-Mn crust precipitation. Velocities in these currents range from 10 to $30 \mathrm{~cm} / \mathrm{s}$, but a velocity of $38 \mathrm{~cm} / \mathrm{s}$ was measured at a depth of $750 \mathrm{~m}$ in the Equatorial Intermediate Undercurrent (Philander, 1973). The first infilling of the early Fe-Mn oxyhydroxides nodules by the nannofossil-foraminifer ooze at MIT Guyot occurred when the guyot was located at about $1^{\circ} \mathrm{N}$ paleolatitude (Larson et al., this volume), and the top of the guyot was at a depth of about $400 \mathrm{~m}$. The projected current velocity of $10-30 \mathrm{~cm} / \mathrm{s}$ is consistent with Bogdanov et al.'s (1990) conclusion, that Fe-Mn crusts precipitate within relatively narrow current limits of $0.5-30 \mathrm{~cm} / \mathrm{s}$. One uncertainty inherent in this conclusion is the impossibility to resolve whether the currents that affected crust deposition on surface of the guyots were of local, or regional scale.

Mid-oceanic topographic features such as seamounts and guyots can be generation sites for internal tidal generated currents (Noble et al., 1988). Internal tidal (wave) generated flows in the mid-Pacific have measured speeds of $2-3 \mathrm{~cm} / \mathrm{s}$, but often may exceed $15 \mathrm{~cm} / \mathrm{s}$ (Noble et al., 1988). Tidal currents measured at a depth of $1200 \mathrm{~m}$ over the Horizon Guyot, located in the eastern mid-Pacific, had a speed of $7.6 \mathrm{~cm} / \mathrm{s}$ (Noble et al., 1988). Such currents have sufficient velocity to remove pelagic sedimentary particles resting on the guyot 
surface and thus erode the guyot surface. This may explain why $\mathrm{Fe}-\mathrm{Mn}$ crusts at the top of guyots are relatively thin in comparison with crusts dredged from the flanks of seamounts, where crust $20-40$ $\mathrm{cm}$ thick was recovered (Friedrich and Schmitz-Wieckowski, 1980).

\section{Oxygen Minimum Zone and Bioproductivity}

A majority of studies of Fe-Mn crusts agree that crusts form on the seamount surfaces located within the oxygen-minimum zone (Bogdanov et al., 1990). The depth range of the oxygen-minimum zone, influenced by the destruction of planktonic organic matter, is quantitatively related to primary productivity. An increase in the surface water productivity and oxidation of sinking organic matter causes a decrease in the $\mathrm{O}_{2}$ concentration in the oxygen-minimum zone and an increase in the concentration of $\mathrm{CO}_{2}$. Whereas the depth of this zone is intrinsically related to changes in the bioproductivity in the surface water column, the physical occurrence of the lower oxygen-minimum zone boundary is modified by the ocean circulation pattern. As a consequence of this, the zone is broader and ranges from 200 to $1600 \mathrm{~m}$ (based on $50 \mu \mathrm{M} / \mathrm{kg}$ of oxygen) in the low-productivity areas of the present northern Pacific Ocean $\left(30^{\circ} \mathrm{N}\right.$ latitude), in contrast to the high-productivity zone in the eastern Pacific, where both boundaries occur at shallower depths of $150-900 \mathrm{~m}$. It should be noted that the lowest oxygen concentrations in the equatorial Pacific were measured near $10^{\circ} \mathrm{N}$ latitude, at $150-600 \mathrm{~m}$ depth (Broecker et al., 1981). The alternation of laminae enriched and depleted in $\mathrm{Mn}$ in W-crusts from Site 876 may be evidence of a past vertical fluctuation of the oxygen-minimum zone lower boundary.

The dissolving organic matter in the oxygen-minimum zone releases biogenic elements, which can then be incorporated into $\mathrm{Fe}-\mathrm{Mn}$ oxyhydroxide deposits. The Fe-Mn oxyhydroxides scavenged a wide spectrum of elements from seawater (Elderfield, 1988) as documented by the chemical composition of the crusts.

Tchuchrov et al. (1989) investigated the precipitation of the main mineral phases of hydrogenic crusts and nodules (Fe-vernadite and Mn-feroxyhyte) and concluded that bacteria are important in the formation of these minerals, as previously inferred from observations of biological structures within (Margolis et al., 1979) and on the surface (e.g., Dudley, 1976) of dredged crusts and nodules and as experimentally confirmed by Bertram and Cowen (1994).

Bogdanov et al. (1990) suggested that during the Cenozoic only the last $20 \mathrm{~m}$.y. represents a period of increased ocean bioproductivity and the development of favorable conditions for crust formation in even the low-productivity areas of the Pacific. Older ferromanganese crusts could have been deposited only in areas of increased bioproductivity, such as in the equatorial zone. Considering that $\mathrm{Fe} / \mathrm{Mn}$ crusts precipitated at MIT Guyot in the equatorial zone of the Pacific during the Late Cretaceous, which from geochemical evidence seems to be a region of a low productivity, the minimal productivity boundary conditions for $\mathrm{Fe} / \mathrm{Mn}$ crust precipitation are yet to be established.

The increased concentration of $\mathrm{Zn}$ in crusts from Wodejebato Guyot and periods of phosphate phase precipitation (Table 4) at the same guyot are a strong indication of nutrient increases and thus increased biogenic productivity during $\mathrm{Fe}-\mathrm{Mn}$ crust precipitation. The timing of this crust precipitation is constrained biostratigraphically as occurring between the late Paleocene and early Eocene. The same time period in the Atlantic Ocean was associated with intensive erosion and changes in the deep water structure, indicating convective overturn and dynamic bottom currents (Berggren and Hollister, 1977). These paleoceanographic changes reflect climatic changes. During the early Paleogene, the higher latitudes began to cool, developing steeper thermal gradients in the oceans (Haq, 1984). Such temperature changes would result in the enhancement of deep and/or intermediate water production at southern high latitudes, which may have resulted in increased equatorial upwelling and associated increases in biogenic productivity as reflected in the chemical composition of the crusts.
Chemical transects across the modern Pacific Ocean (GEOSECS) show that the highest concentration of phosphate and nitrate occur north of about $5^{\circ} \mathrm{N}$ and at about $1000 \mathrm{~m}$ water depth (Broecker et al., 1981). Hein et al. (1985) similarly observed that, on the average, phosphorite content increases in the crusts with decreasing latitude. Even though chemical analyses are lacking for most of the southern group guyots investigated during this study, the difference in composition between M- and W-crusts supports Hein et al.'s (1985) observation of more abundant phosphate in crusts formed at lower latitudes. However, this latitudinal affinity could be only apparent. As discussed previously, the guyots currently located further to the north in the northwestern Pacific migrated across the equatorial belt during the Late Cretaceous (M-crusts), which we suggest was a time of low productivity even in the equatorial region. In contrast, the southern guyots migrated through the same latitudinal belt during the late Cenozoic (W-crusts), which as a result of major changes in the ocean circulation, has been a high-productivity region (Jansa et al., unpubl. data).

That the Fe-Mn crusts of the southern group of guyots were formed when the seamounts were crossing the high-productivity equatorial zone may be proposed from an increase in concentrations of $\mathrm{Zn}$ and $\mathrm{Ni}$ in W-crust, in comparison to M-crusts. $\mathrm{Zn}$ is considered to be one of the micronutrients necessary for diatoms; thus, increases in the concentration of $\mathrm{Zn}$ in crusts may suggest metal enrichment associated with the dissolution of siliceous plankton (Fenner, this volume).

\section{CONCLUSIONS}

The chemical and mineralogical composition of ferromanganese crusts and nodules collected from plateau areas of the guyots in the northwestern Pacific Ocean during Leg 144 show that they are mainly hydrogenous deposits; that is, they have been formed by the slow accumulation of trace metal-enriched $\mathrm{Fe}$ and $\mathrm{Mn}$ oxides directly from the seawater column. The major and trace element geochemistry of Fe-Mn crusts provides evidence regarding the variability in mineralogical and chemical composition of the Fe-Mn crust deposited at the top of a single guyot, notwithstanding differences between different guyots, even though their tops are located in similar water depth.

Considering that $\mathrm{Fe}-\mathrm{Mn}$ oxyhydroxide precipitation at some of the guyots may have continued for longer than 30 m.y., the interpretation of chemical and mineralogical composition of the Fe-Mn crusts must involve close consideration of paleogeographic and paleoceanographic parameters since the seamounts have moved horizontally (Fig. 3), riding migrating oceanic plates across the equator and the same time experienced a vertical displacement as a result of isostatic subsidence (Fig. 2B). Such motions exposed the top of northwestern Pacific guyots to seawater of a variable chemical composition, influencing fertility, rate of biogenic carbonate production, plankton dissolution, which in turn has a controlling effect on metal concentration in seawater and extrinsically on ferromanganese crust composition. The crust composition appears to be strongly affected by changes in biological productivity in surface waters, by the development and position of the oxygen-minimum zone, and extrinsically by changes in the paleolatitudes of the guyots.

$\mathrm{Fe}-\mathrm{Mn}$ crust precipitation was initiated when the guyots migrated into the equatorial belt and their surface subsided below the North and South Equatorial Countercurrents (NECC, SECC) and Equatorial Undercurrent (EUC) realms, where the recent current velocities range from 35 to $170 \mathrm{~cm} / \mathrm{s}$ (Philander, 1973; Gouriou and Toole, 1993; Tomszak and Godfrey, 1994). The domain of these currents bottoms near $317 \mathrm{~m}$ depth for NECC, SECC and at less than $200 \mathrm{~m}$ for the EUC (Philander et al., 1987), thereby delineating the upper boundary limit for Fe-Mn crust precipitation. This conclusion is supported by the guyot subsidence analyses, which shows that the Fe-Mn crust precipitation was initiated when the surface of the guyots subsided to about $400 \mathrm{~m}$ of water depth (Fig. 3). The Fe-Mn crust precipitation continued as the guyots subsided through the Equatorial Intermediate 
Undercurrent domain. Below $800 \mathrm{~m}$ water depth the current velocity in the equatorial Pacific decreases to $<30 \mathrm{~cm} / \mathrm{s}$ (Tomszak and Godfrey, 1993), which allows pelagic carbonate accumulation and results in smothering of Fe-Mn crust precipitation.

The oldest crust sampled during Leg 144 is of late Santonian to early Campanian age, with crust precipitation continuing until late Eocene (Premoli Silva, Haggerty, Rack, et al., 1993). However, at the periphery of some of the guyots the process might continue to the present. Lower average rate of about $0.7 \mathrm{~mm} / \mathrm{m}$.y. for M-crust precipitation in comparison with an average precipitation rate of 0.8 $\mathrm{mm} / \mathrm{m}$.y. for W-crusts supports precipitation of M-crust in a lower productivity realm.

The dominance of asbolane-buserite assemblage in W-crusts with minor contribution in $\mathrm{M}$-crusts contrasts with the dominance of $\mathrm{Fe}$ vernadite (typical low-productivity mineral phase) in M-crusts. However, this phase is also present in W-crusts documenting a strong influence of local hydrological and environmental conditions on crust composition. Consequently, results obtained from analysis of crusts from a single location over a guyot should not be considered representative of processes affecting the whole seamount and the adjacent water column.

Chemical analyses of crusts show silica and aluminum enrichment in crusts from MIT Guyot, suggesting an influx of wind-borne particles by trade winds from the Asian continent. Positive $\mathrm{Ce}$ anomalies were identified in all except four samples of W-crusts, further indicating the effect of local conditions on crusts composition. Concentrations of $\mathrm{Co}(<0.5 \%)$ in crusts from both the Wodejebato and MIT Guyots are much lower than the $2 \%$ maximum predicted by Halbach and Puteanus (1984) for crusts from seamount plateaus.

The chemical compositions of the Fe-Mn crusts from northwestern Pacific guyots indicate that the equatorial Pacific Ocean was a low-productivity region during the Late Cretaceous, with periods of increased biogenic productivity during the late Paleocene and early Eocene. We relate increases in productivity to paleoceanographic changes, particularly to an intensification of equatorial upwelling as a consequence of intensified Subantartctic Intermediate Water circulation, as the southern polar region began to cool down. However, confirmation of this hypothesis requires much wider data base than available for this study.

\section{ACKNOWLEDGMENTS}

The laboratory studies were supported by a grant from the Russian Foundation of Fundamental Investigations (Grant No. N93-05-9270). L. Jansa acknowledges the support of the Geological Survey of Canada in his participation in Leg 144. Nelly Koziel assisted in typing the manuscript and T. Schell and F.C. Thomas in reviewing the English. J.P.M. Syvitski provided calculations of settling velocities and flow conditions from pelagic sediment size distribution, R.L. Larson made available data for guyots subsidence and calculated paleolatitudinal positions of the guyots. The manuscript has been critically reviewed and significantly improved by helpful comments from E.H. De Carlo, D.K. Watkins, and F. Rack. Geological Survey of Canada Contribution 33694.

\section{REFERENCES}

Aplin, A.C., 1984. Rare earth element geochemistry of Central Pacific ferromanganese encrustations. Earth Planet. Sci. Lett., 71:13-22.

Baturin, G.N., Tambiev, S.B., Liapunov, S.M., 1986. Rare earth elements in ocean biogenic phosphates. Geochimiya, 11:1636-1643.

Berggren, W.A., and Hollister, C.D., 1977. Plate tectonics and paleocirculation: commotion in the ocean. Tectonophysics, 38:11-48.

\footnotetext{
- Abbreviations for names of organizations and publication titles in ODP reference lists follow the style given in Chemical Abstracts Service Source Index (published by American Chemical Society)
}

Bertram, M.A., and Cowen, J.P., 1994. Testate rhizopod growth and mineral deposition on experimental substrates from Cross Seamount. Deep-Sea Res., 41:575-601.

Bogdanov, Y.A., Sorochtin, O.G., Zonenshain, L.P., Kuptzov, V.M., Lisitzina, N.A., and Podrajanski, A.M., 1990. Ferromanganese Crust and Nodules of Pacific Seamounts: Moscow (Nauka). (in Russian)

Bowen, A.J., Normark, W.R., and Piper, D.J.W., 1984. Modelling of turbidity currents on Navy Submarine Fan, California continental borderland. Sedimentology, 31:169-185.

Broecker, W.S., Spencer, D., and Craig, H., 1981. GEOSECS Pacific Expedition (Vol. 4): Sections and Profiles: Washington (Nat. Sci. Found.)

De Baar, H.J.W., Bacon, M.P., Brewer, P.G., and Bruland, K.W., 1985a. Rare earth elements in the Pacific and Atlantic oceans. Geochim. Cosmochim. Acta, 49:1943-1959.

De Baar, H.J.W., Brewer, P.G., and Bacon, M.P., 1985b. Anomalies in rare earth distributions in seawater: Gd and Tb. Geochim. Cosmochim. Acta, 49:1961-1969.

De Carlo, E.H., 1991. Paleoceanographic implications of rare earth element variability in a marine Fe-Mn crust from the central Pacific Ocean. Mar. Geol., 98:449-467.

De Carlo, E.H., and McMurtry, G.M., 1992. Rare-earth element geochemistry of seamount ferromanganese crusts from the Hawaiian Archipelago, central Pacific. Chem. Geol., 95:235-250.

Dubinin, A.V., 1993. Mass-spectrometry with inductive related plasma: determination of rare earth elements in standard samples of ocean deposits. Geochimiya, 11:1605-1619.

Dubinin, A.V., and Baturin, G.N., 1994. Rare earth elements in standard samples of iron-manganese ores and clay. Oceanologia, 34:228-231.

Dudley, W.C., 1976. Cementation and iron concentration in foraminifera on manganese nodules. J. Foraminiferal Res., 6:202-207.

Elderfield, H., 1988. The oceanic chemistry of the rare-earth elements. Philos. Trans. R. Soc. London A, 325:105-126.

Elderfield, H., and Greaves, M.J., 1981. Negative cerium anomalies in the rare earth element patterns of oceanic ferromanganese nodules. Earth Planet. Sci. Lett., 55:163-170.

1982. The rare earth elements in seawater. Nature, 296:214-219.

Elderfield, H., and Pagett, R., 1986. Rare earth elements in ichthyoliths: variations with redox conditions of depositional environment. Sci. Total Environ., 49:175-197.

Friedman, G.M., Sanders, J.E., and Kopaska-Merkel, D.C., 1992. Principles of Sedimentary Deposits: New York (Macmillan).

Friedrich, G., and Schmitz-Wiechowski, A., 1980. Mineralogy and chemistry of a ferromanganese crust from a deep-sea hill, Central Pacific, Valdivia cruise, VA 13-2. Mar. Geol., 37:71-90.

Goldberg, E.D., Koide, M., Schmitt, R.A., and Smith, R.H., 1963. Rare earth distribution in the marine environment. J. Geophys. Res., 68:4209-4217.

Gorshkov, A.I. Dritz, B.A., Beresovskaia, B.B., and Sivtzov, A.B., 1991. Mineral composition and origin of seamount crusts and nodules. Izv. Akad. Nauk SSSR, Ser. Geol., 7:67-76.

Gorshkov, A.I., Mochov, A.V., Dritz, V.A., Davydenko, E.Y., and Sivtzov, A.B., 1994. High-resolution electron microscope images of crystal lattices of minerals with a lamellae structure: chlorite-vermiculite, lithiophorite, and nickel absolane. Geol. Ore Deposits, 36:284-288.

Gouriou, Y., and Toole, J., 1993. Mean circulation of the upper layers of the western Equatorial Pacific Ocean. J. Geophys. Res., 98:22495-22520.

Gromet, L.P., Dymek, R.F., Haskin, L.A., and Korotev, R.L., 1984. The "North American Shale Composite": its composition, major and trace element characteristics. Geochim. Cosmochim. Acta, 48:2469-2482.

Halbach, P., Manheim, T., and Otten, P., 1982. Co-rich ferromanganese deposits in the marginal seamount regions of the Central Pacific Basin: results of the Midpac '81. Erzmetall, 35:447-453.

Halbach, P., and Puteanus, D., 1984. The influence of the carbonate dissolution rate on the growth and composition of $\mathrm{Co}$-rich ferromanganese crusts from Central Pacific seamount areas. Earth Planet. Sci. Lett., 68:73-87.

Halbach, P., Segl, M., Puteanus, D., and Mangini, A., 1983. Co-fluxes and growth rates in ferromanganese deposits from central Pacific seamount areas. Nature, 304:716-719.

Haq, B.U., 1984. Paleoceanography: a synoptic overview of 200 million years of ocean history. In Haq, B.U., and Milliman, J.D. (Eds.), Marine Geology and Oceanography of Arabian Sea and Coastal Pakistan: New York (Van Nostrand Reinhold), 201-231.

Hein, J.R., Bohrson, W.A., Schulz, M.S., Noble, M.A., and Clague, D.A., 1992. Variations in the fine-scale composition of a Central Pacific ferromanganese crust: paleooceanographic implications. Paleoceanography, 7:63-77. 
Hein, J.R., Manheim, F.T., Schwab, W.C., and Davis, A.S., 1985. Ferromanganese crusts from Necker Ridge, Horizon Guyot and S.P. Lee Guyot: geological considerations. Mar. Geol., 69:25-54.

Kang, J.K., 1987. Mineralogy and internal structures of ferromanganese crust from a seamount, central Pacific. Han'guk Haeyang Hakhoechi [J. Oceanol. Soc. Korea], 22:168-178.

Klinkhammer, G., Elderfield, H., and Hudson, A., 1983. Rare earth elements in seawater near hydrothermal vents. Nature, 305:185-188.

Koeppenkastrop, D., and De Carlo, E.H., 1992. Sorption of rare-earth elements from seawater onto synthetic mineral particles: an experimental approach. Chem. Geol., 95:251-263.

Margolis, S.V., Dugolinsky, B.K., and Dudley, W.C., 1979. Microchemistry and morphology of biogenic, detrital and authigenic phases in Pacific manganese nodules. In La Genèse des Nodules de Manganèse. Colloq. Int. C.N.R.S., 289:179-209.

McNutt, M.K., Winterer, E.L., Sager, W.W., Natland, J.H., and Ito, G., 1990. The Darwin Rise: a Cretaceous superswell? Geophys. Res. Lett., 17:11011104.

Menard, H.W., 1964. Marine Geology of the Pacific: New York (McGrawHill).

Millero, F.J., and Sohn, M.L., 1992. Chemical Oceanography: Boca Raton (CRC Press).

Murray, R.W., Leinen, M., and Isern, A.R., 1993. Biogenic flux of Al to sediment in the central equatorial Pacific Ocean: evidence for increased productivity during glacial periods. Paleoceanography, 8:651-670.

Noble, M., Cacchioni, D.A., and Schwab, W.C., 1988. Observations of strong Mid-Pacific internal tides above Horizon Guyot. J. Geophys. Res., 18:1300-1306.
Palmer, M.R., 1985. Rare earth elements in foraminifera tests. Earth Planet. Sci. Lett., 73:285-298.

Parsons, B., and Sclater, J.C., 1977. An analysis of the variation of ocean floor bathymetry and heat flow with age. J. Geophys. Res., 82:803-827.

Philander, S.G.H., 1973. Equatorial undercurrent: measurements and theories. Rev. Geophys. Space Phys., 11:513-570.

Philander, S.G.H., Hurlin, W.J., and Seigel, A.D., 1987. Simulation of the seasonal cycle of the tropical Pacific Ocean. J. Phys. Oceanogr., 17:19862002.

Premoli Silva, I., Haggerty, J., Rack, F., et al., 1993. Proc. ODP, Init. Repts., 144: College Station, TX (Ocean Drilling Program).

Sager, W.W., Winterer, E.L., Firth, J.V., et al., 1993. Proc. ODP, Init. Repts., 143: College Station, TX (Ocean Drilling Program).

Syvitski, J.P.M., and Schafer, C.T., in press. Evidence for an earthquaketriggered basin collapse in Sequenay Fjord, Canada. Sediment. Geol.

Tchuchrov, F.B., Gorshkov, A.I., and Dritz, B.A., 1989. Hypergene Oxides of Manganese: Moscow (Nauka).

Tomczak, M., and Godfrey, J.S., 1993. Regional Oceanography: An Introduction: Oxford (Pergamon Press).

Date of initial receipt: 12 July 1994

Date of acceptance: 23 January 1995

Ms 144SR-057 
1

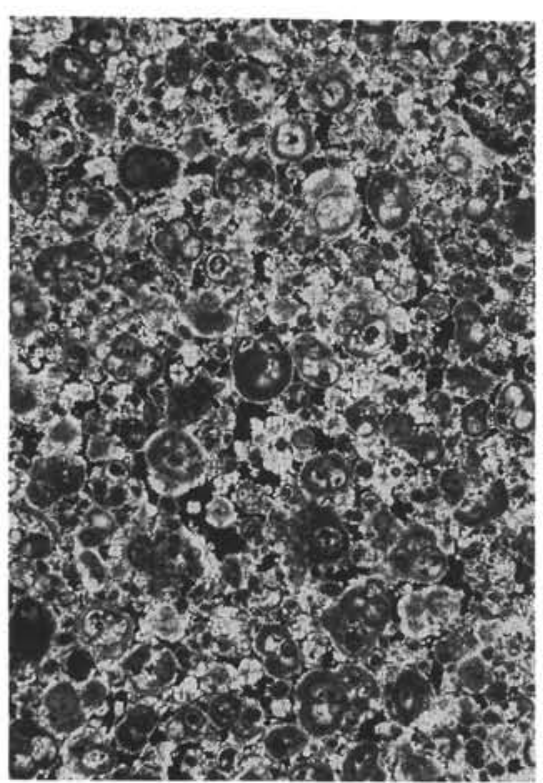

3

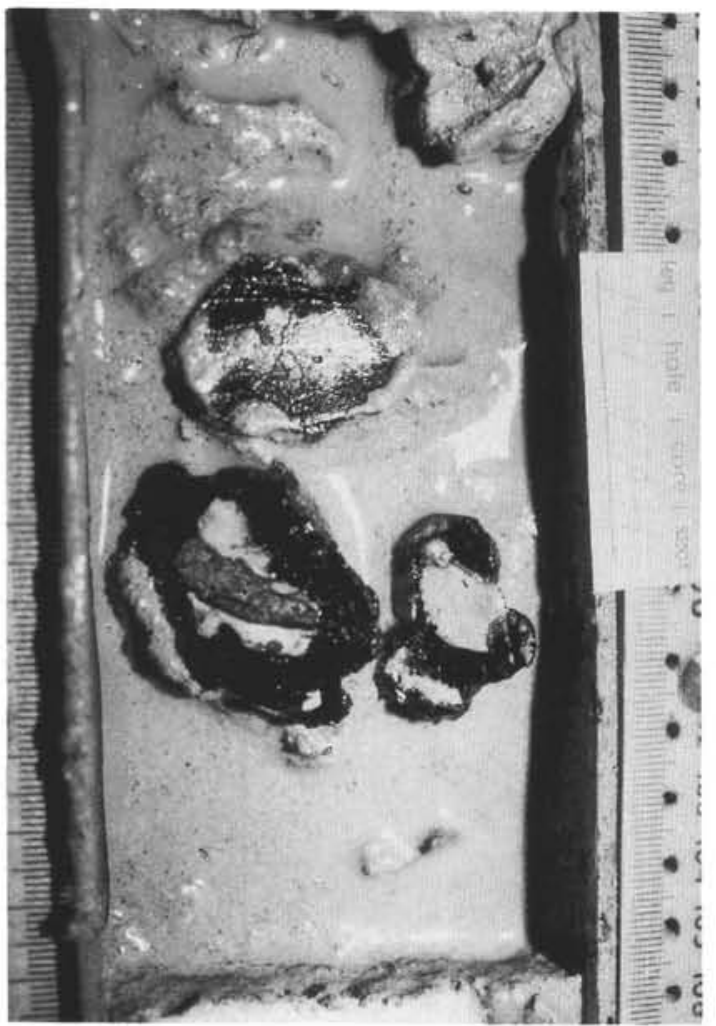

2

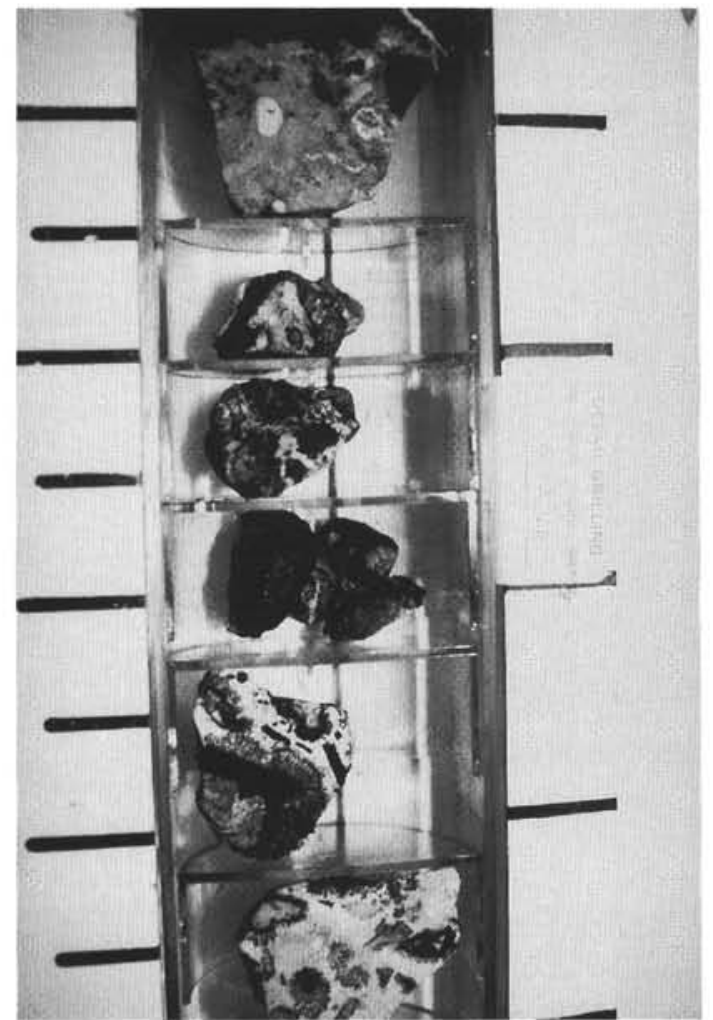

4

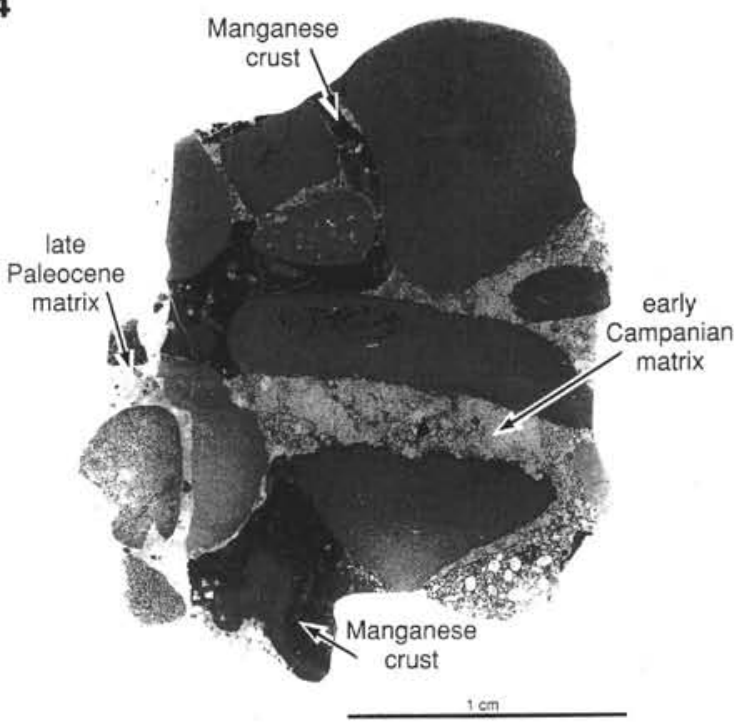

Plate 1. Photomicrographs and core photographs of crusts. 1. Well-sorted foraminiferal ooze that overlies Fe-Mn crust at Lo-En Guyot, thin section (Sample 144-872A-17H-3, 122-124 cm; crossed polars, plus gypsum plate. 2. Core photograph showing complete sequence across the basal pebbly bed at Wodejebato Guyot (interval 144-873A-1R-1, 0-45 cm). Shallow-water limestone pebbles are coated by Fe-Mn oxyhydroxides with rims of manganese dendrites growing into pelagic carbonate matrix composed of foraminiferal packstone. The skeletal grainstone underlying the uppermost crust, which is $1.5 \mathrm{~cm}$ thick, shows several episodes of bioturbation and burrow infilling by pelagic carbonate. 3. Close-up of $\mathrm{Fe}-\mathrm{Mn}$ nodules, some of which enclose phosphatized limestone nuclei buried in nannofossil-foraminifer ooze (MIT Guyot, interval 144-878A-1R-1, 5-30 cm). 4. Photomicrograph of a thin section made from a pebble in the basal conglomerate at Lo-En Guyot (Sample 144-872B-4R-1, 13-16 cm). It demonstrates the multicyclic origin of the pebble derived from a lithified conglomerate, in which pebbles were already partially encrusted by Fe-Mn crust, some of which was incorporated as broken fragments, before the interparticle voids were infilled by an early Campanian pelagic carbonate matrix. 
1

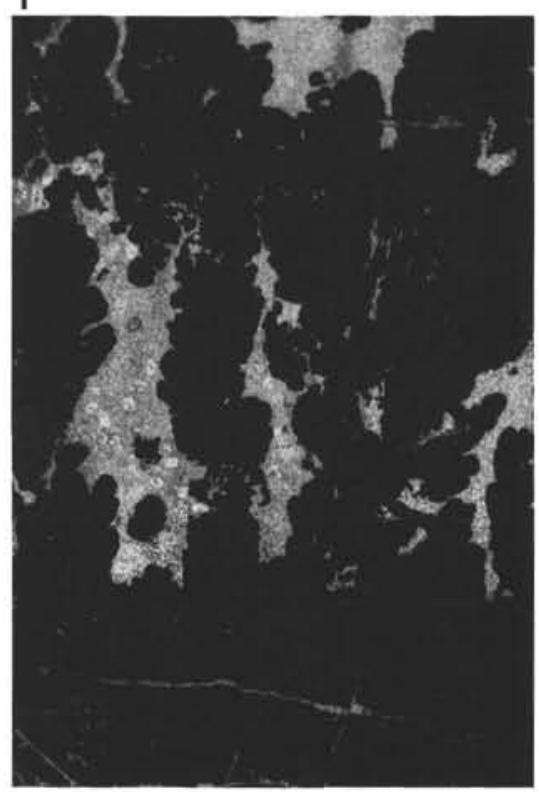

3

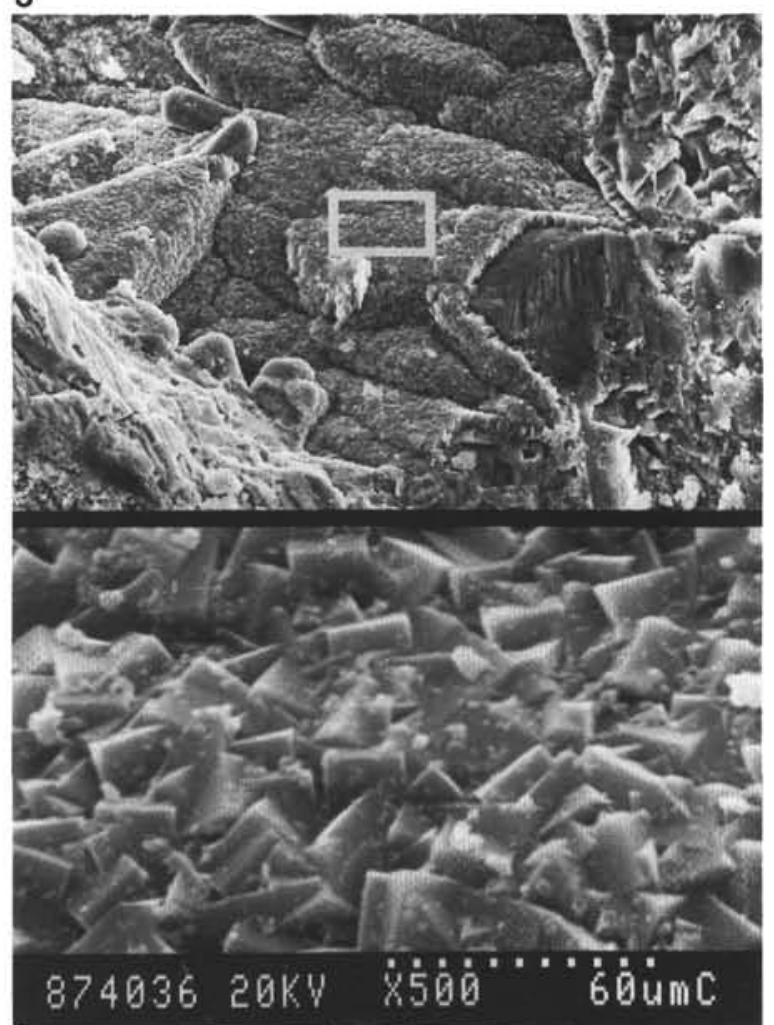

2

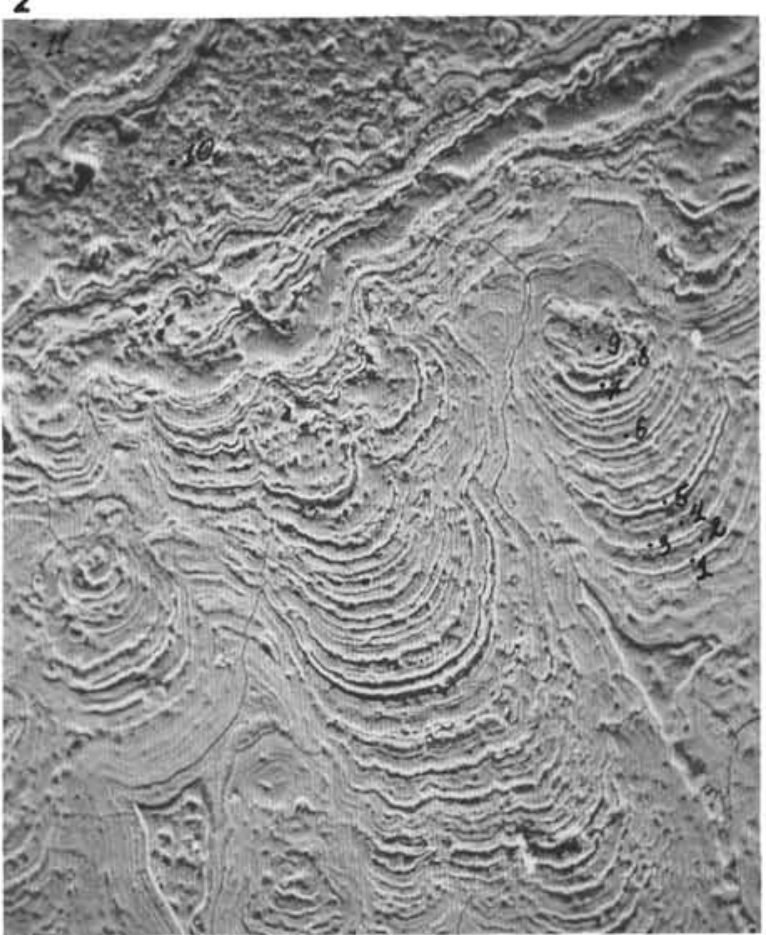

4

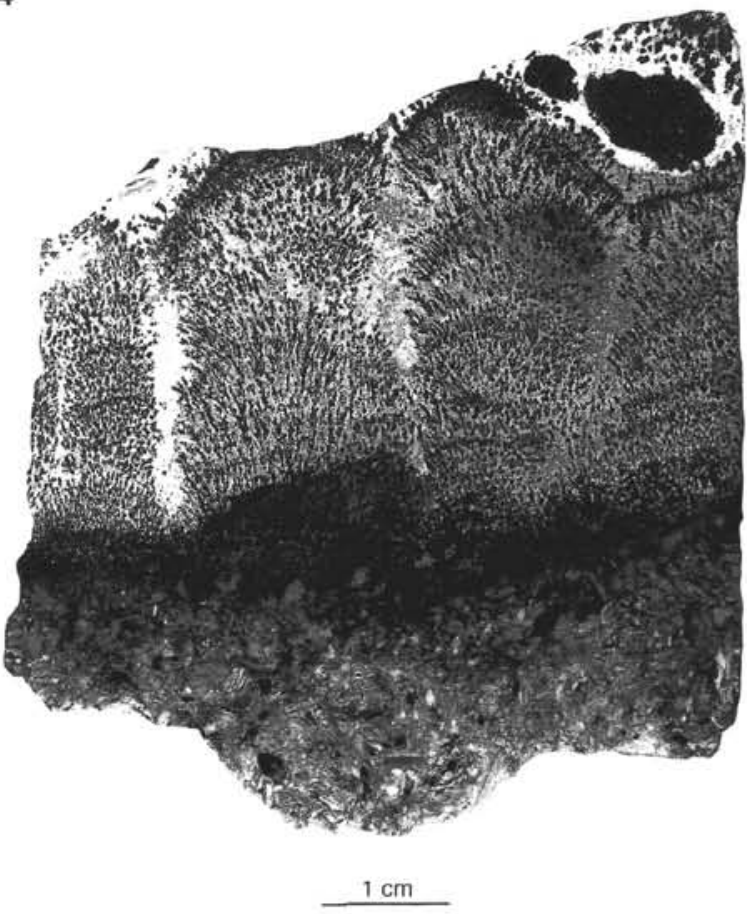

Plate 2. 1. Massive ferromanganese laminae overlain by a network of digitate hydrous manganese dendrites, some of which enclose foraminifer tests. Pelagic limestone is composed by highly packed, well-preserved calcareous nannofossils, planktonic foraminifers, and ostracodes that fill the interstices of the manganese dendrites. In some interstices, higher accumulations of foraminifer tests near the base are an indication of weak geopetal fabric. The nannofossil assemblage indicates early late Eocene age of the pelagic carbonate (Sample 144-873A-1R-1, 0-5 cm; thin section, crossed nicols plus gypsum plate). 2. Structure of ferromanganese crust at Wodejebato Guyot (Sample 144-873A-1R-1,35-36 cm). Numbers show position of samples for microchemical analysis given in Table 1. Visible is alternation of thin laminae and "dendrite" laminae in the crust. White = pelagic carbonate residues in space between ferromanganese dendrite "pillars." 3. Apatite crystals on the surface of ferromanganese deposits (Sample 144-874B-1R-1, 7-10 cm). The upper frame shows the location of magnified Fe-Mn crust shown by the lower frame. 4. Close-up core photograph of columns of manganese dendrites that extend into pelagic limestone from the surface of thin Fe-Mn crust coating either surface of a shallow-water carbonate platform, or a limestone clast (interval 144-875C-1M-1, 7-14 cm). 


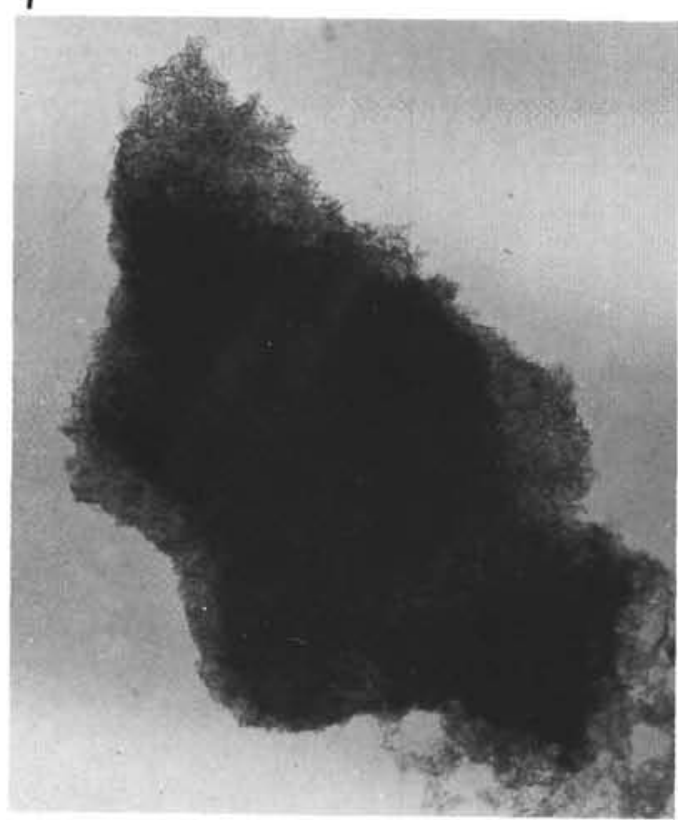

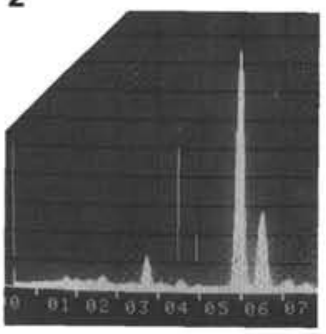

3

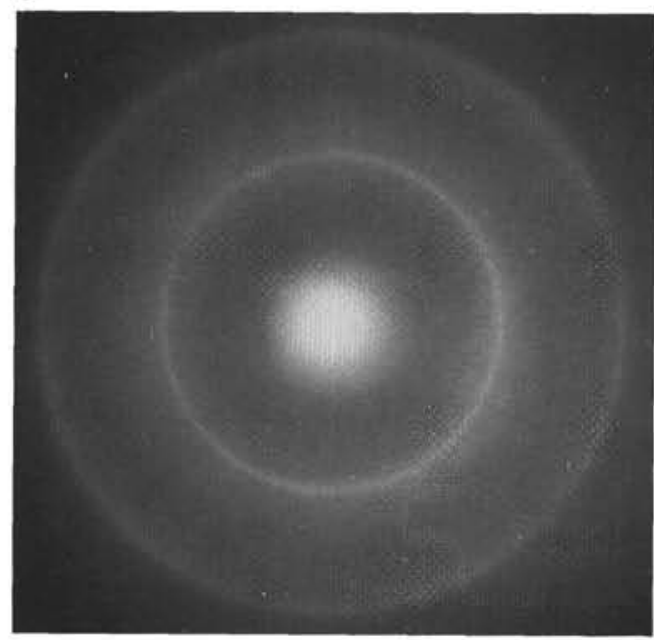

4

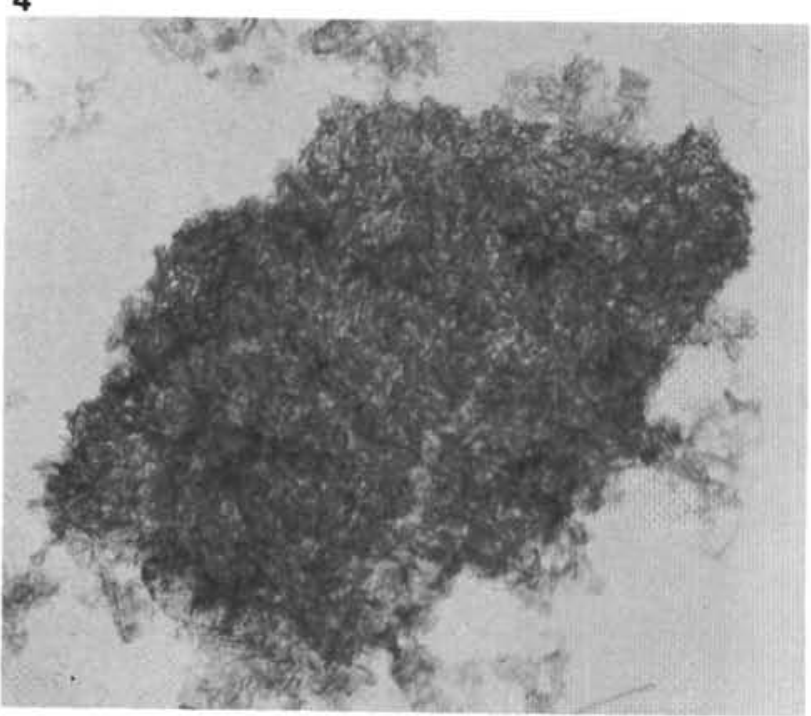

5

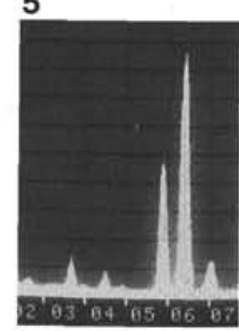

6

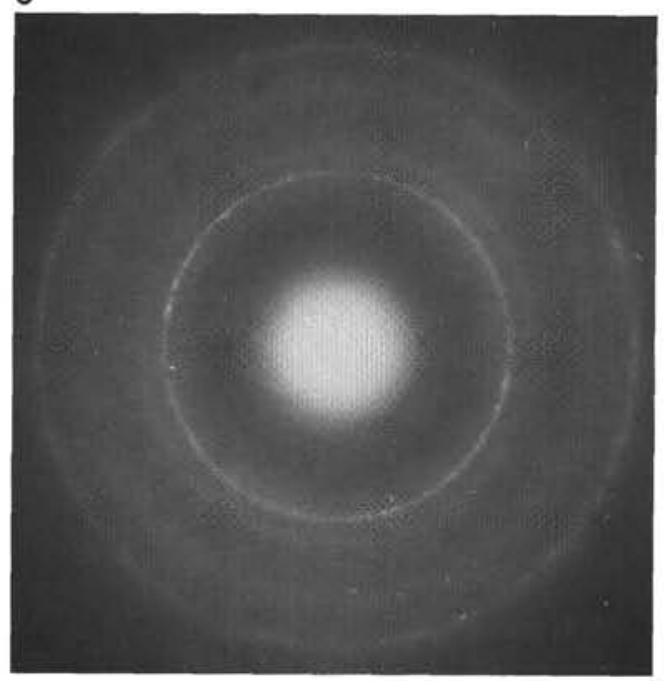

Plate 3. 1. Electron photomicrograph of fine scaly aggregates of Fe-vernadite. 2. Energy dispersion spectrum. 3. Electronogram of the same mineral. Numbers in parentheses $=$ identified reflection of crystallographic planes (100). 4. Electron photomicrograph of fine scaly aggregates of Mn-feroxyhyte. 5. Energy dispersion spectrum. 6. Electronogram of the same mineral. Numbers in parentheses = identified reflection of crystallographic planes (100). 

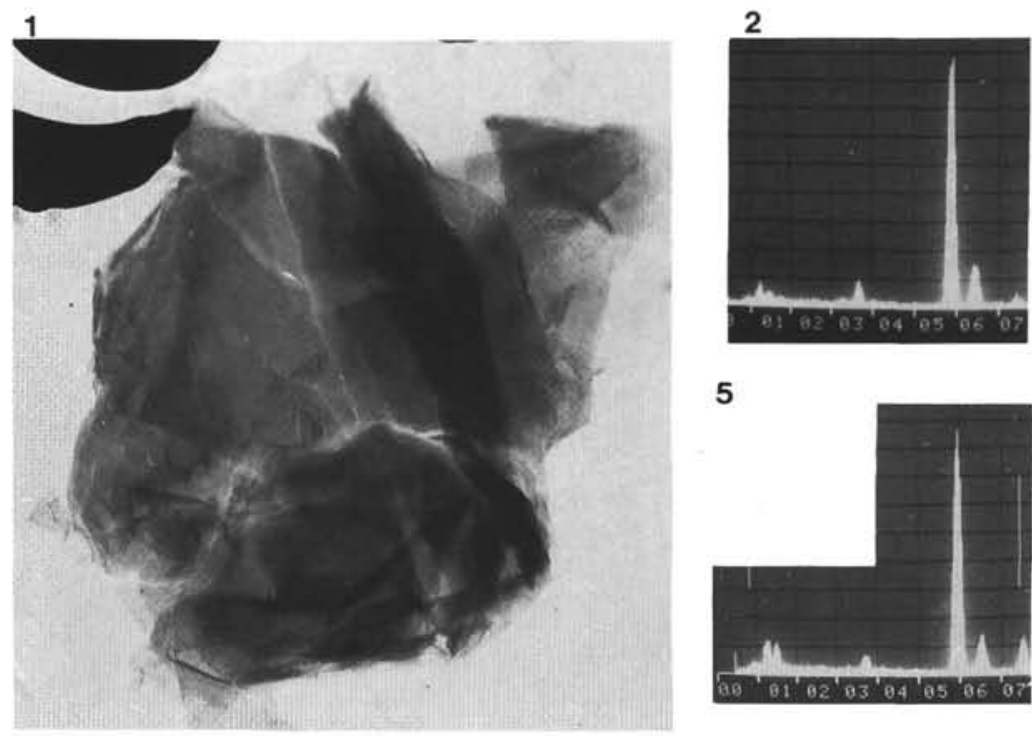

3

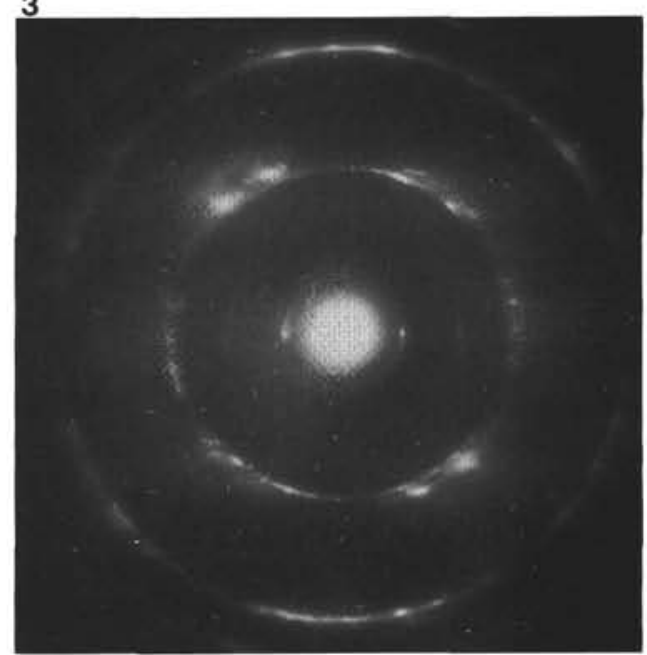

6

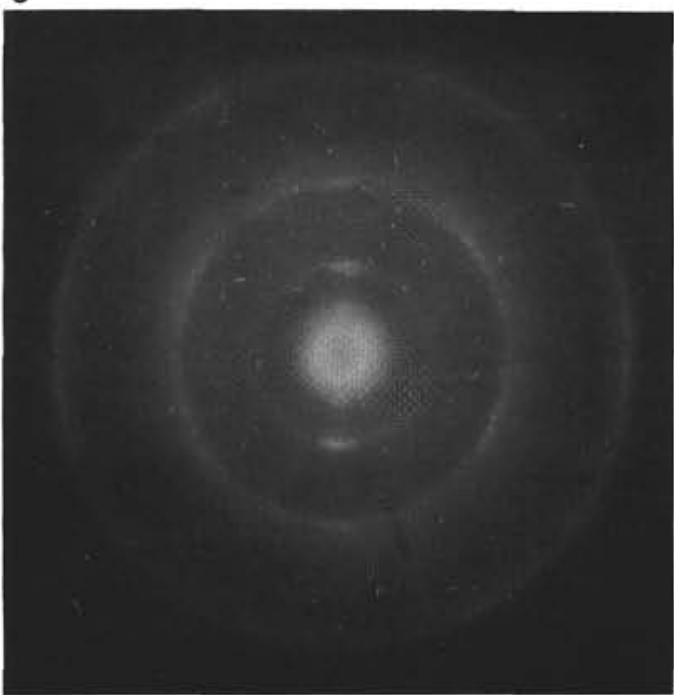

Plate 4. 1. Electron photomicrograph of birnessite plate. 2. Energy dispersion spectrum. 3. Electronogram of the same mineral. 4. Electron photomicrograph of scaly aggregate of mix-layered asbolane-buserite. 5. Energy dispersion spectrum. 6. Election diffraction pattern of the same mineral. 
1

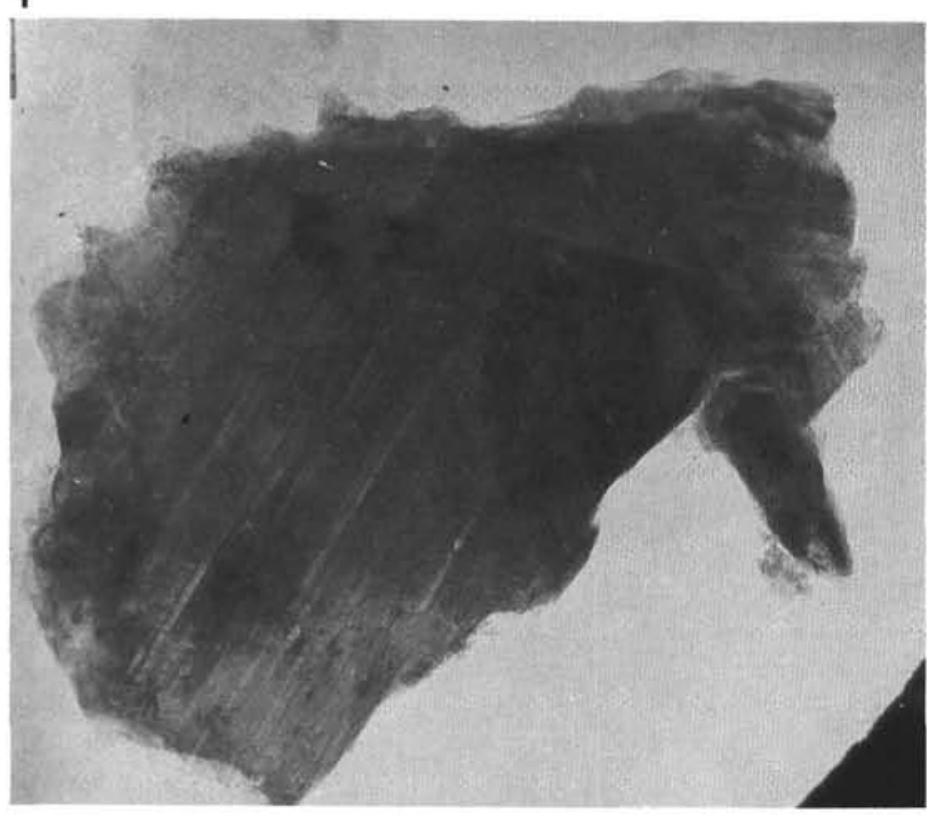

2

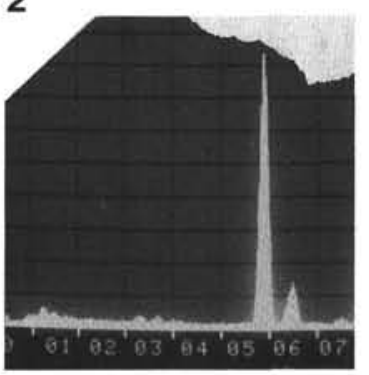

3

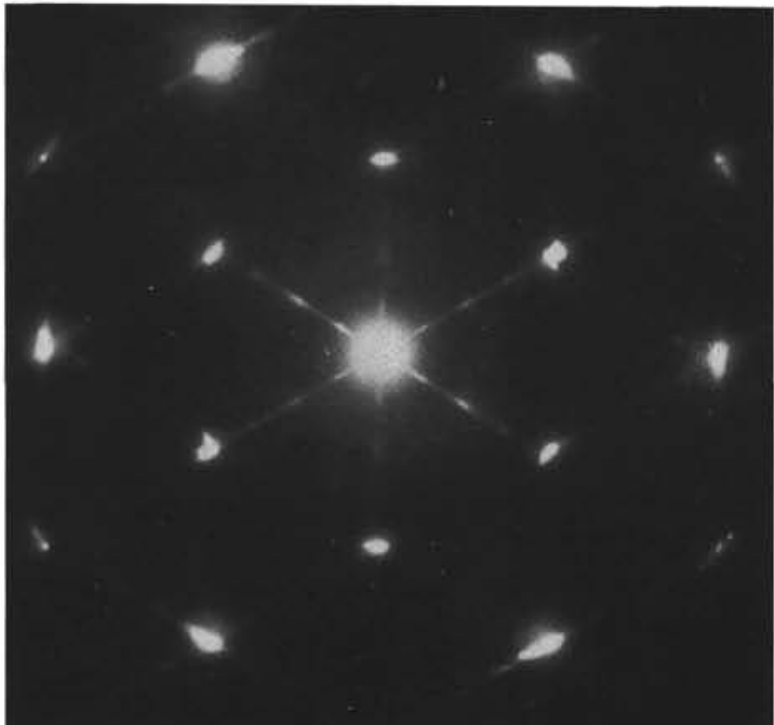

Plate 5. 1. Electron photomicrograph of todorokite plate. 2. Energy dispersion spectrum. 3. Electronogram for triple crystal intergrowth of this mineral. Indicated is position of crystallographic axis $\left(a_{1}, a_{2}, a_{3}\right)$. 
1

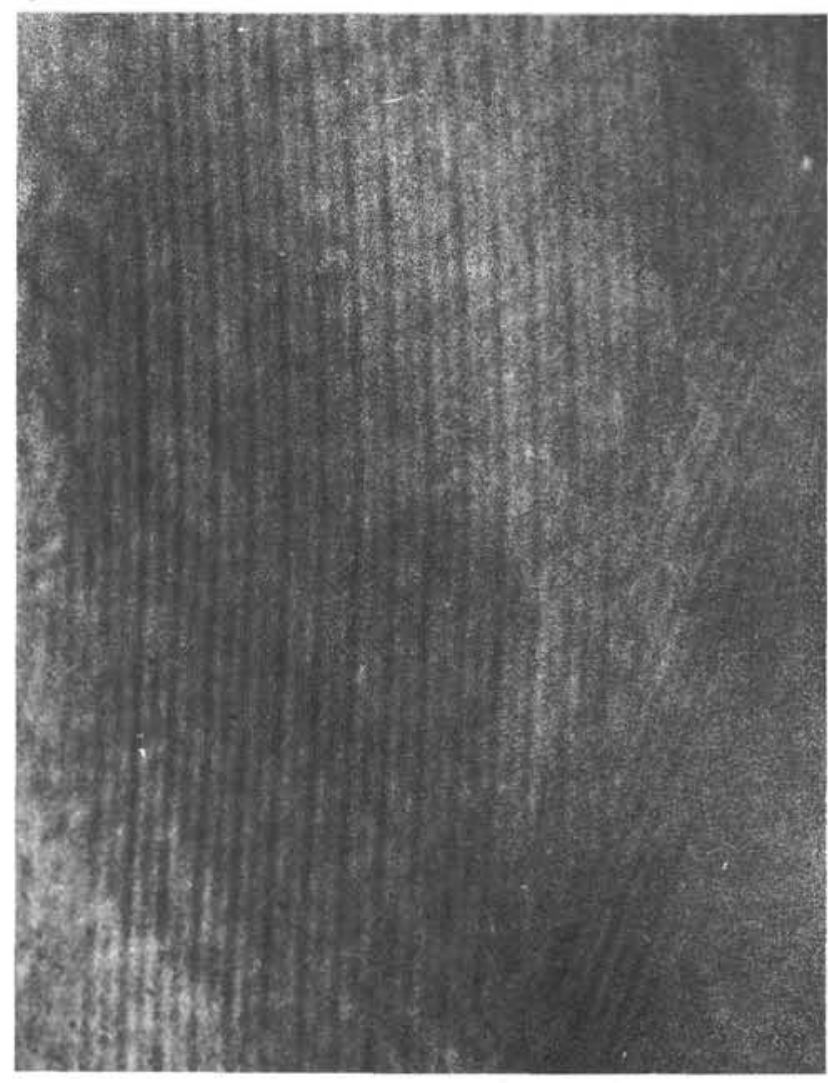

3

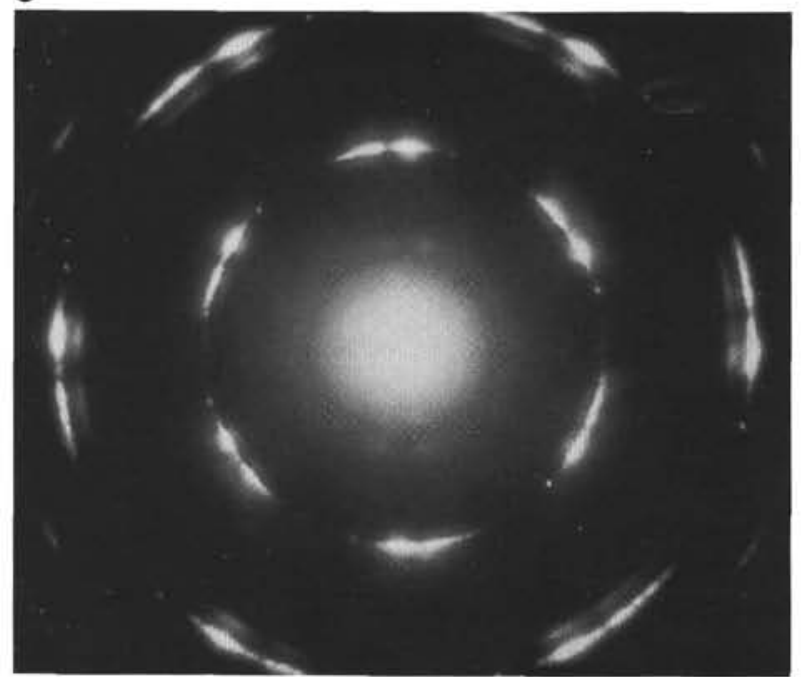

Plate 6. 1. Electron photomicrograph of lattice of a mixed-layer Ni-asbolane. 2. Energy dispersion

spectrum. 3. Electron diffraction pattern with Miller indices of reflections of crystallographic planes (001). 4. Only basal plane (001) reflections.

2

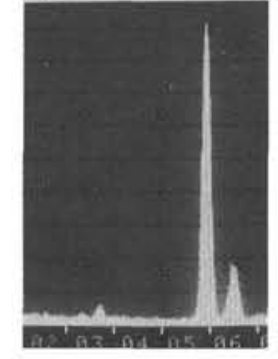

4

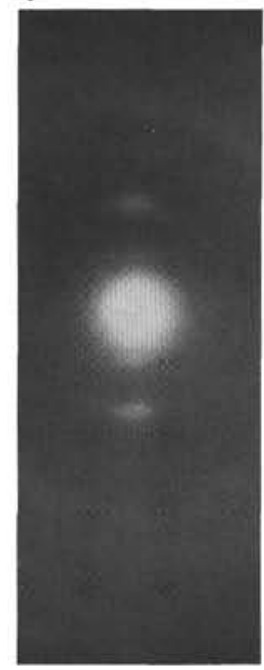

